Portland State University

PDXScholar

$1-1-1974$

\title{
A study of the physiological factors affecting the biological conversion of arsenite to arsenate
}

Shirley E. Phillips

Portland State University

Follow this and additional works at: https://pdxscholar.library.pdx.edu/open_access_etds Let us know how access to this document benefits you.

\section{Recommended Citation}

Phillips, Shirley E., "A study of the physiological factors affecting the biological conversion of arsenite to arsenate" (1974). Dissertations and Theses. Paper 822.

https://doi.org/10.15760/etd.822

This Dissertation is brought to you for free and open access. It has been accepted for inclusion in Dissertations and Theses by an authorized administrator of PDXScholar. Please contact us if we can make this document more accessible: pdxscholar@pdx.edu. 
A STUDY OF THE PHYSIOLOGICAL FACTORS AFFECTING THE BIOLOGICAI CONVERSTON OF ARSENITE TO ARSENATE

by

SHIRLEY E. PHILLIPS

A thesis submitted in partial fulfillment of the requirements for the degree of

DOCTOR OF PHILOSOPHY

In

ENVIRONMENTAI SCIENCES AND RESOURCES - BIOLOGY

Portland State UnIversity

1974 
TO THE OFFICE OF GRADUATE STUDIES AND RESEARCH:

The members of the Comitte approve the thesis of

Shirley E. Phillips presented 8 October 1973.

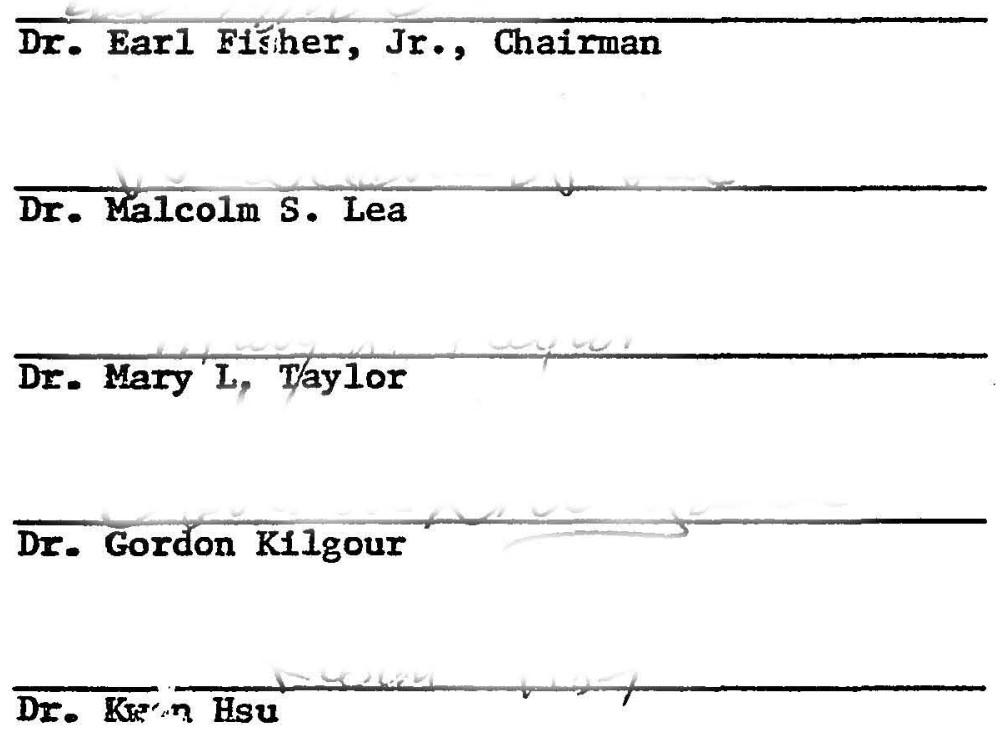

DI. $\mathrm{Ku}_{\mathrm{T}} \mathrm{n \textrm {HSU }}$

APPROVED:

Ear1 Fisher, Jr., Head, Department of Biology

Dávíd T. Clark, Dean of Craduate Studies 
AN ABSTRACI OF THE THESIS OF Shirley E. Phillfps for the Doctor of

Philosophy in Environmental 3ciences and Resources - Blology

presented on 8 October 1973.

Title: A study of the Physiological Factors Affecting the Bfological

Conversion of Arsenite to Arsenate

APPROVED BY MEMBERS OF THE THESIS COMMTTEE

Dr. Earl Fisher, Jr., Chairman

Dr. Malcoln S. Lea

Dr. Mary L. Taylor

Dr. Gordon Kj.Igour

Dr. Kwan Hsu

Ex-Officio:

Dr. Karl Dittmer, Environmental Science Coordinator

Dr. David Clark, Graduate Studies and Research

Dr. Frederick Cox, Graduate Council Representative 


\section{ABSTRACT}

Although arsenic is ubiquitous in the environment, certain forms of arsentc are added deliberately in ever increasing quantitles. The addition of large quantities of the trivalent inorganic form (arsenite) could pose a serious hazard because of the toxicity of this form explicable in terms of its action of sulfhydryl containing enzymes and/or coenzymes. In the environment arsenite is rapidly converted to arsenate (the pentavalent inorganic form). Since a biological explanation for the oxidation of arsenite to arsenate was available only for cattle dips (a unique environment), this study was undertaken to examine sewage for the presence of arsenite oxfdizing bacteria. The isolation of bacteria capable of arsenite oxidation would allow a study of cultural and physiological propertfes and thus provide information useful in making rational decisions regarding the continued use of inorganic arsenicals as pesticides; as well as elucidating one segment of the arsenic cycle. Thlrty-four different strains of arsenite oxidizing pseudomonads were isolated from sewage and classified into two major groups, Pseudomonas fluorescens-arsenoxydans and Pseudomonas acidovorans-arsenoxydans, with three and four ecotypes in each group. One particularily rapid arsenite oxidizing strain (designated Pseudomnnas acidovorans-arsenoxydans YE56) was extensively studied. A minimal, defined medium was used to study the relationship of temperature, $\mathrm{pH}$, aeration and nutrition to growth of this organism versus the ability of the organism to convert arsenite to arsenate under the same conditions.

The conversion of arsenite to arsenate in YE56 was shown to be due to the appearance at stationary phase of an enzyme and/or component 
of the electron transport system when the organism is grown in chemically defined medium. In contrast, induction of the arsentte oxidizing system occurs in late exponential growth phase when the organism is grown in a rich medium. Thus, even though cell populaticns may never reach stationary phase in sewage, the ability of organisms to oxidize arsentte is probably constant. No energy could be detected from the ozddation of arsenite as measured by increase in growth rate or total cell yield. The adaptability of this organism to the changing environmental conditions of a sewage plant helps explain the findings that pseudomonads are the predominant species in sewage.

A simple, unambiguous method for the separation of arsenite, arsenate and phosphate, using a combination of thin layer chromatography and paper chromatography, is described which makes it possible for investigators to define arsenic determinations to include the form (organic or inorganic), oxidation state (trivalent or pentavalent) and the quantity present in the samples. 
PAGE

IIST OF TABLES. $\ldots \ldots \ldots \ldots \ldots \ldots \ldots \ldots \ldots \ldots \ldots \ldots \ldots \ldots \ldots \ldots \ldots \ldots \ldots \ldots \ldots . . \ldots$

IIST OF FIGURES............................... vili

INTRODUCTION.................................... 1

MATERTALS AND METHODS............................. 8

Estimation of Total Arsenic...................... 8

Estimation of Arsenite......................... 8

Estimation of Arsenate.......................... 8

Total Protein............................. 9

Separation of Arsenite and Arsenate................. 11

Estimation of Mass and Number of Bacterlal Cells......... 12

Measurement of Arsenite Oxidation by Respitometry........ 13

Isolation of Bacterta......................... 20

Identification Techniques........................ 21

Determination of Conditions for Optimum Growth Rate and Cell Yield............................. 26

Determination of Conditions for Maximum Arsenite

Oxidation.................................... 29

RESULTS...................................... 30

Separation of Arsenite and Arsenate................ 30

Isolation................................. 35

Growth Factor Requirements...................... 35

Identification............................. 47 
PAGE

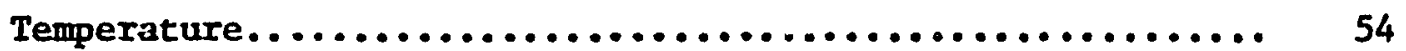

Aeration..................................... 58

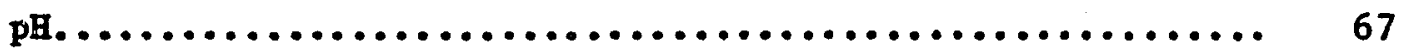

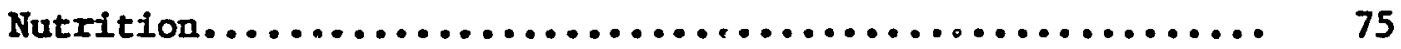

DISCUSSION..................................... 117

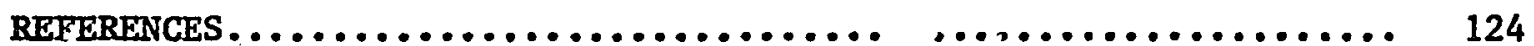




\section{LIST OF TABLES}

TABLE

PAGE

I Deliberate Additions of Arsenite to the Blosphere....... 2

II Deliberate Additions of Arsenate to the Biosphere........ 4

III Toxicity of Sodium Arsenite and Arsenate Towards

Some Llving Things (p.p.m As)................... 6

IV Effect of Arsenite and Arsenate on the Lowry Protein

Determination Klett Readings (非66 Filter)............ 10

v Separation of Arsenicals and Phosphate by Thin

Layer Chromatography.........................

VI Separations of Arsenicals and Phosphate by Paper

Chromatography.

VII Growth of Isclates on Various Carbon Sources............

VIII General Characters of Diagnostic Value for the

Differentiation of Two Groups of Aerobic Pseudomonads....

IX Nutritional Characters of Diagnostic Value for the

Differentiation of Species of Aerobic Pseudomonads.......

X The Group Characters of Greatest Differential Value in

the Recognition of the Fluorescent Psuedomonads......... 44

XI Characters for the Differentiation of $\underline{P}$. Fluorescens

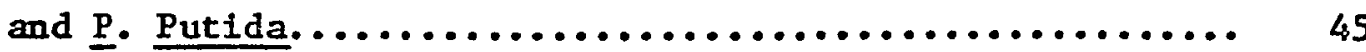

XII The Group Characters of Greatest Differential Value in the Recognition of the Acidovorans Group............. 46

XIII Speciflc Requirements of the Nutritionally Exacting Strains................................... 
XIV Determination of Specific Amino Acid Requirements

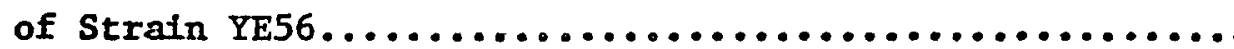

IV Determination of Speditic Amino Acid Requirements of Strain YE56.............................. 52

XVI Relationship Between Grewth and Concentrations of

Two Required Amino Acrds.......................

XVII Arsneite Remaining Afcer Three Days of Growth for

Each Isolate in Two Different Media.................

XVIII The Effect of Temperature on the Growth of

Pseudomonas Acidovorang-ersenoxydans YE56.

XIX The Effect of Temperature on the Rate of Arsenite

Oxidation by Washed Suspensions of Pseudomonas

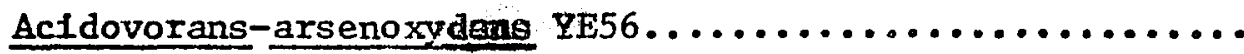

8X Relationship Between Gronth and Flask Size at

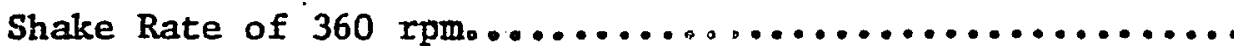

XXI. The Effect of Aeration the Doubling Time and

Ce11 Yield of Strain Yes6.

XXII The Effect of the $\mathrm{pH}$ of the Medium on Doubling Time

and Cell Yield of Strain YE56.....................

XXIII The Effect of Growth pH on Arsenite Oxidizing

Activity In Growing Cuztures of YE56................. 74

XXIV The Effect of Vitamin Supplement on the Doubling

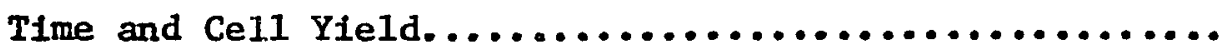


XXV The Effect of Varying Concentrations of Sodium Citrate on the Growth Rate and Generation Time of Pseudomonas Acidovorans-arsenoxydans YE56............ 82

XXVI Activity of Arsenity Oxidizing System Grown in Different Carbon Sources.......................... 83

XXVII Effect of Substrate Addition on Arsenite Oxidizing Activity in Pseudomonas Acidovorans-arsenoxydans

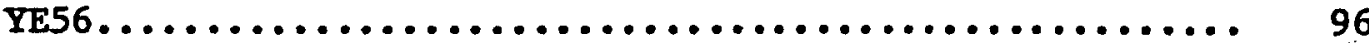

XXVIII The Effect of Culture Filtrate on Arsenite

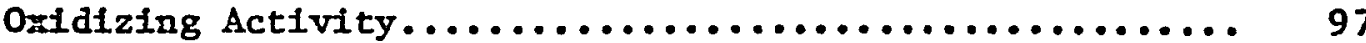

XXIX Enzymatic Conversion of Arsenite to Arsenate by Pseudomonas Acldovorans-arsenoxydans YE56............ 102 XXX Cell Yields from the Aerobic Growth of Pseudomonas Acidovorans-arsenoxydans on Chemically Defined Media..... 113 XXXI Cell Yields from Aerobic Growth of Heterotrophs.......... 114 
1 Calibration of Number of Viable Cells per ml Culture versus Klett Reading.....................

2 Calibration of Milligrams of Cellular Protein per $m l$ of Culture as a Function of klett Reading...........

3 Absorption Spectrum of Oxidized and Reduced 2,6 DIchlorophenolindophenol...................

4 Correlation of Optical Density with the Concentration of 2,6 Dichlorophenolindophenol.................

5 Typical TLC Chromatogram showing Separation of Arsenate, Arsenite and Phosphate.................

6 Typical Paper Chromatogram Showing Migration of

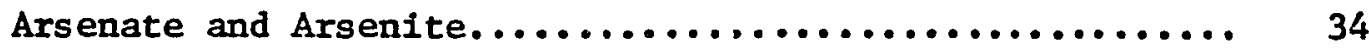

7 Disappearance of Sodium Arsenite from Sewage.......... 36

8 Thin Layer Chromatography Showing Sodium Arsenite Disappearance from Sewage...................... 37

$9 \quad$ Pseudomonas $\mathrm{sp}$. (YE56) Shwolng Polar Flagella......... 48

10 Arrhenius Plot of the Rate of Arsenite Oxidation........ 60

11 Effect of Aeration on the Growth of Pseudomonas

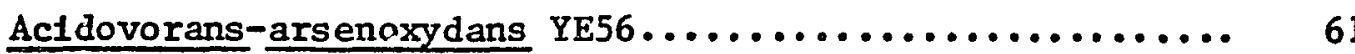

12 The pH Optimimi of washed Cells of Pseudomonas Acidovorans-arsenoxydans YE56 with the Dissociation Curves of Arsenious and Arsenic Acid............... 70

13 The $\mathrm{pH}$ Optimum of Washed Cel1s of Pseudomonas Acldovorans-arsenoxy Żäs YE56 in Varlous Buffers........ 71 
14 The Effect of Various Buffers on the Growth of YE56

In the Presence and Absence of Arsenite............. 72

15 The Effect of Arsenite on the Growth of YE56 in

Vartous Buffers..............................

16 Time Course of Appearance of Arsenite Oxidizing

Enzymes in a Culture of Pseudomonas Acidovorans-

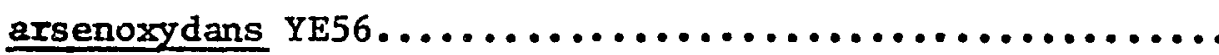

17 Growth of YE56 in Graded Amounts of Magnesium with

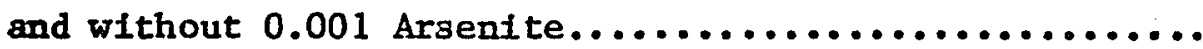

18 The Effect of Varying Concentrations of Casamino Acids

on Doubling Time and Final Cell Yleld in Strain YE56.....

19 Growth Curve of Pseudomonas Acidovorans-arsenoxydans

YE56 with and without the Addition of Arsenite..........

20 Growth of Pseudomonas Acidovorans-arsenozydans YE56

Measured by Viable Cell Count and Turbidity Showing

Lysis at Early Stationary Phase...................

21 Dependance of Cell Viability on Diluent Composition......

22. Iytic Pattern of Stationary Growth Phase with the

Addition of Various Ions.......................

23 Diagram Showing that the Arsenite-oxidizing System of

Pseudomonas Acidovorans-arsenoxydans Strain YE56 is

Induced....................................

24 Induction of Arsenite 0xidizing Capacity in an

Exponentially Growing, Previously noninduced Culture

of Pseudomonas Acidovorans-arsenoxydans YE56. 
25 Relationship Between Growth, Arsenite Oxidation

and pH.

26 Plot Showing the Production of Arsenate and the Responsibility of the Arsenate for the Characteristic pH Changes During Growth in an Arsenical Medium.

27 The Disappearance of Arsenite and the Appearance of Arsenate in the Enzymatic Conversion of Arsenite to

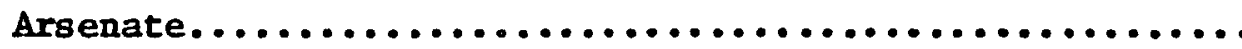

28 The Enzymatic Conversion of Arsenite to Arsenate by YE56 In Growlng, Previously Noninduced Cells.

29 The Rate of Arsenite Oxidation by a Washed Suspension of Maximally Induced Whole Cells by Pseudomonas

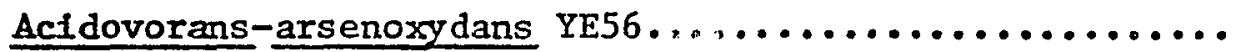

30 The Effect of Arsenite Concentration on Velocity of

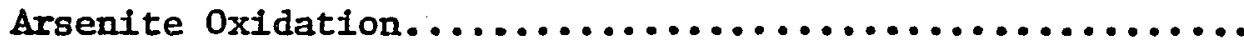

31 Diagram Showing that a Culture of Pseudimonas Acldovorans-arsenoxydans YE56 Maxima1ly Induced to Oxidtze Arsenite Possesses a Cytochrome that can Oridize Reduced 2,6 Dichlorophenolindophenol.......... 


\section{INTRODUCTION}

Two blologically important forms of inorganic arsenic (metal arsenttes and metal arsenates) are found in nature. The trivalent form (arsenic trioxide, $\mathrm{As}_{2} \mathrm{O}_{3}$ ) is a by-product of the smelting of ores such as Iron, lead, zinc, copper, manganese, gold and silver. Prior to technological advances in smelting, trivalent arsenic was found chiefly deep in the earth's crust in ores as the arsenide or as the sulfur arsenide of heavy metals, e.g. arsenopyrite (FeAss).

Arsenic trioxide $\left(\mathrm{As}_{2} \mathrm{O}_{3}\right)$ when dissolved in water immediately is altered to arsenious acid. It is not known whether this acid is present as $\mathrm{HAsO}_{2}$ or as some hydrate of this form but it is commonly written as $\mathrm{H}_{3 \mathrm{ABO}}$. In the past 100 years commercially produced metal arsenites have been added to the biosphere deliberately as pesticides. Some examples of arsenites added to the biosphere in recent years are shown in Table I. In additicn, unknown quantities of arsenites are added annually as herbicides and soil sterilants (Wilkinson and Hardcastle, 1969), and rodenticides (biocides) (Harrison, 1972).

The word "arsenic" has come to mean "poison" because the toxicity of trivalent arsenic is well known. The action of arsenite has been explained (Mahler and Cordes, 1966) by the inhibition of respiratory metabolism, especially inactivation of 1ipolc acid dependent enzymes such as the pyruvate dehydrogenases and alpha-ketoglutarate dehydrogenase complexes. Odorless, tasteless, and resembling powdered sugar, 0.1 to 0.3 gram of arsenic trioxide is usually fatal for a 65 kflogram person (Sollmann, 1957). 
TABLE I

DELIBERATE ADDITIONS OF ARSENITE TO THE BIOSPHERE

SOURCE

Insecticide ${ }^{a}$

Aquatic herbicide

(Shapiro, 1971)
LOCALITY

California

Minnesota lakes

New York lakes
AMOUNT

172,879 lbs $1 / 1 / 71$ to $9 / 1 / 71$

$900,0001 \mathrm{bs}$

$1956-1969$

$85,0001 \mathrm{bs}$

$1961-1966$

a Harrison, Tom. Pesticide Supervisor Plant Diviston, Oregon State Department of Agriculture.

Personal communication. 
Pentavalent arsenic (arsenic acid, $\mathrm{H}_{3} \mathrm{AsO}_{4}$ or its heavy metal salts) is also extensively used as shown in Table II. Angino et al. (1970) found that the treatment processes now used in many sewage and waste effluent plants do not remove the arsenic so that arsenates in wastewater containing presoaks and detergents pass through sewage treatment plants into public water systems. In contrast arsenates added to solls in fertilizers or as pesticides remain in the soil as relatively insoluble complexes. Since they are leached from the soil and enter public water systems via ground water only slowly, arsenates added to soils accumulate over a period of years to concentrations which cause a phytotoxic response (U. S. Department of Agriculture yearbook, 1957). Arsenates can substitute for phosphate in some substrate level phosphorylation reactions (Doudoroff et a1., 1947; Katz and Hassid, 1951) and there is some evidence that arsenate can act as an uncoupler of oxidative phosphorylation (Terwelle and Slater, 1964; Crane and Lipmann, 1953). In addition the energy rich compound, carbamyl phosphate, which is a substrate for the enzymatic synthesis of citrulline and ureidosuccinate undergoes arsenolysis (Jones, 1962).

- In 1918 Green isolated a bacterium, from a dilute lecoction of stable manure containing arsenite, buffered with potassium phosphate, which in pure culture was able to oxidize arsenite to arsenate. In 1949 Turner reported the isolation of 15 strains of arsenite oxidizing bacteria from arsenite cattle dips. He concluded the organisms entered the dip either from soll or feces and made some postulations concerning the nature of the respiratory system which brought about the oxidation of arsenite to arsenate by these organisms. Since cultures of Greer.'s 


\section{TABLE II}

DELIBERATE ADDITIONS OF ARSENATE TO THE BIOSPHERE

SOURCE

Presoaks and household detergents (Angino, 1970)

Superphosphate fert111zers from marine

Phosphorltes (Schroeder and Balassa, 1966)

Insect1cldes: ${ }^{a}$

Lead arsenate on Callfornia grapes

Lead arsenate on fruit trees

Sodium arsenate on Calffornia vegetables

Calcium arsenate on vegetable and frult trees
AMOUNT OF ARSENATE

10 - 70 micrograms/gram

$100-200$ mferograms/gram

\author{
$72,1931 \mathrm{bs}$ \\ $1 / 1 / 71-9 / 1 / 71$ \\ Unestimated \\ $6,156 \mathrm{lbs}$ \\ $1 / 1 / 71-9 / 1 / 71$ \\ Unestimated
}


orlginal bacterium had been lost, Turner was unable to make any direct comparisons.

Until the present investigation there has been no adequate means for distinguishing between the two inorganic forms of arsenic (arsenite and arsenate) and therefore, only total arsenic was determined. For example, Angino et al. (1970). reported the detection of arsenic at a concentration of 10-70 micrograms As per gram of presoaks and household detergents and concluded that these concentrations were high enough to pose a serious water pollution problem and a potential health hazard to people constantly exposed to these products. Preliminary experiments conducted in this laboratory using the chromatographic procedures to differentiate between arsenite, arsenate and phosphate indicate that the arsenic present in detergents and presoaks is in the form of arsenate. In this form arsenic does not accumulate in human tissues but Is excreted rapidly through the kidneys. Thus, of greater biological significance for humans because of its toxicity is the addition of trivalent arsenic to waters and soil. Table III compares the toxicity of arsenite and arsenate for various living forms as reported by the California State Water Quality Criteria, 1963. It appears from Table III that arsenite is more toxic than arsenate for the species tested. Shapiro (1971) has stated that monitoring of waste waters for phosphate has been in error since any arsenate present in the waters reacts as phosphate in the colorimetric assays which have been routinely used. He postulated that the source of the arsenate was probabiy from the large quantities of sodium arsenite added to the Minnesota iakes to kill rooted aquatic plants. He assumed that the arsenite was rapidly 
TABLE III

TOXICITY OF SODIUM ARSENITE AND ARSENATE

TOWARDS SOME LIVING THINGS (p.p.m As)

\section{Item}

Bacteria

Algae

Yeast

Daphnia magna

Flatworms

Minnows

Minnows

Minnows

Rats and mlce, $96 \mathrm{hr} \mathrm{LD}_{50}$ oral

MLD, intraperitoneal
Arsenite

290

5.2

40

20

17.8

11.6

11.2

5.8

\section{Arsenate}

$>10,000$

$>1,000$

300

12.5

361

250

234

60

112

$2: 1$

California State Water Quality Criteria (1965) 
oxfdized to arsenate, the arsenate thus formed persisted in the waters since it had low involvement in biological processes. Schroeder and Balassa (1966) state that arsenite present in soil or rock exposed to the atmosphere is oxidized slowly to arsenate. Since no blological explanation for the oxidation of arsenite to arsenate in lakes had been shown, a study was undertaken to examine soll and sewage for the presence of arsenite oxidizing bacteria. The isolation of bacteria capable of arsenite oxidation would allow a study of their cultural and physlological properties, and thụ provide information useful in making rational decisions regarding the continued use of inorganic arsenicals as pesticides. 
MATERIALS AND METHODS

Estimation of Total Arsenic

The silver diethyldithiocarbamate colormetric procedure as outlined by the Association of Official Analytical Chemists (1970) was followed. A standard curve was prepared with each set of determinations. Absorbance remained linear over the range 1 to 20 micrograms arsenic per sample with a relative error of 15.8 percent.

Estimation of Arsenite

A starch solution and a $0.005 \mathrm{~N}$ iodine solution were prepared and standardized according to the procedure of Rieman, Neuss and Naiman (1942). Since iodine solutions are unstable, they were standardized within a week of their use in analysis. The iodometric titration of arsenite was performed as described by Levvy (1943) and the special precautions of Gilreath (1969) observed. It has been possible to adapt this technique to detect as little as 50 micrograms arsenite per sample with a relative error of 7.4 percent.

\section{Estimation of Arsenate}

The Fiske and Sưbarow colorimetric method for determining inorganic phosphate (Fiske and Subbarow, 1925) was modified for quantitative arsenate determination as follows: An appropriate aliquot of the standard solution (arsenic acid) or sample solution containing 5 to 25 micrograms arsenate was diluted to $5 \mathrm{ml}$ with aistilled water. 0re $\mathrm{ml}$ of ammonium molybdate solution was added to the sample; the color was developed in the sample by the addition of $0.5 \mathrm{ml}$ Fiske and Subbarow reagent In the same way. After addition of each reagent the sample was mixed 
vigorously using a vortex mixer. A blank containing distilled water or buffer was prepared with each determination. The tubes were incubated at room temperature for 75 minutes and the amount of color determined using a Klett-Summerson colorimeter with a $\$ 66$ filter or read at $660 \mathrm{~nm}$ In a Bausch and Lomb Spectronic 20. Since color increased with time without coming to a maximum it was decided to allow the tubes to stand exactly 75 minutes at room temperature and then read all the tubes within 15 minutes. (The same intensity of color could be developed by incubatIng the tubes 15 minutes at $50^{\circ} \mathrm{C}$.) A standard curve was always prepared with each set of assays. Absorbance remained linear over the range 5 through 25 micrograms arsenate per sample with a relative error of less than 5 percent. Sodium arsenite, cacodylic acid and Tris buffer at concentrations used in these experiments had no effect on arsenate determinations.

\section{Total Protein}

Proteln concentrations were measured with the Folin phenol reagent as described by Lowry et al. (1951) using bovine serum albumin (BSA) as the standard. As shown in Table IV, arsentte at concentratIons above $10^{-4} \mathrm{M}$ interfered in the determination of protein by this procedure; however, arsenate, even at $10^{-2} \mathrm{M}$, gave no color. In order to determine protein in the presence of unknown concentrations of arsenite, a modified procedure was developed: Instead of one reagent blank for all the samples, from each sample a blank was prepared by removing the bacterial cells using a millipore filter. This filtrate was used as the reagent blank for the pair thus compensating for the 
TABLE IV
EFFECT OF ARSENITE AND ARSENATE ON THE LOWRY PROTEIN DETERMINATION
KLETT READINGS (非6 FILTER)

\begin{tabular}{|c|c|c|c|c|}
\hline & Orig BSA & $30 \mu g$ BSA & $50 \mu \mathrm{g}$ BSA & $90 \mathrm{Hg}$ BSA \\
\hline Standard assay mixture & - & 52 & 96 & 157 \\
\hline$+1 \times 10^{-2} \mathrm{M}$ arsenate & 0 & 52 & 96 & 157 \\
\hline$+1 \times 10^{-4} \mathrm{M}$ arsenite & 0 & 56 & 96 & 154 \\
\hline$+1 \times 10^{-3} \mathrm{M}$ arsenite & 2 & 67 & 96 & 157 \\
\hline$+1 \times 10^{-2} M$ arsenite & 17 & 68 & 105 & 178 \\
\hline
\end{tabular}


differences in arsentte concentration in samples. Although it could be shown that a linear relationship between klett units and arsenite concentration existed in the range 0.01 to $0.06 \mathrm{M}$ arsenite, these concentrations were too high to be useful as a sensitive arsenite assay.

Separation of Arsenite and Arsenate

Thin Layer Chromatograph (TLC). Chromatographic separation of arsenite and arsenate was performed on $5 \times 20$ or $20 \times 20 \mathrm{~cm}$ aluminum sheets pre-coated with $0.25 \mathrm{~mm}$ layers of silica ge1 F-254 (Brinkman Instruments). In order to remove impurities, the sheets were run in the approprlate developing solvent and air drled prior to sample application. Water solutions of standards and samples were applied at intervals, 1.5 cm from the bottom of the plate and developed at room temperature by ascending one of the three following solvent systems:

1. methanol: concentrated ammonium hydroxide: $10 \%$ trlchloroacetic acid:water $(65: 15: 5: 15)$

2. n-butanol:acetic acid:water $(80: 20: 20)$

3. n-propanol:25\% ammonium hydroxide (2:1)

Using these solvent systems, more than two hours was required for the solvent front to advance $15 \mathrm{~cm}$.

Since under many conditions inorganic arsenite and arsenate migrate without distinct separation, the following technique was developed to distinguish unambigously between the two forms. After drying the developed chromatogram was exposed to lodine vapors in a closed chamber. Only the arsenite reacts with the iodine to give a brown spot on a light yellow background. After removal the chromatographic plate was left in the air until the brown spot lightened and the background 
color disappeared. The chromatograms were first sprayed with a 1 percent ammonium molybdate solution, dried at room temperature and then sprayed with a 1 percent stannous chloride solution; colored spots appeared. A typical chromatogram is shown under results.

Paper Chromatography. Whatman \#1 chromatography paper $22.5 \mathrm{x}$ $53.5 \mathrm{~cm}$ was washed in the developing solvent and air dried prior to sample application. Water solutions of standards and samples were applied $5 \mathrm{~cm}$ from the paper edge and developed for time periods ranging from elght hours to overnight in a glass descending chromatography apparatus using one of the following solvent systems:

1. $1.0 \mathrm{M}$ ammonium acetate in $95 \%$ ethanol

2. n-butano1:acetic acid:water ( $4: 1: 5$ both phases)

(This procedure requires a longer time but as shown under results this method allows a complete separation of arsenite and arsenate.)

Estimation of Mass and Number of Bacterial Cells

Estimation of Viable Cell Number. Dilutions (the various diluents are stated in the results) of a bacterial culture were mixed with various melted agar media and pour plates were made to slow down the motility and thus obtain isolated colonies. Duplicate plates were made for each estimation. Since no clumping was observed by microecopic examination of samples during growth, each viable bacterium was assumed to give rise to a visible colony. Plates were incubated at $37^{\circ} \mathrm{C}$ for 48 hours and the number of colonies was counted.

Estimation of Dry Weight. Dry weights were estimated by flltering 50 to $100 \mathrm{ml}$ aliquots of a culture through a millipore filter which had been preweighed on an analytical balance to $1 \mathrm{mg}$. The filter and cell 
mass was allowed to dry for two hours at room temperature and reweighed. Turbidity. Turbidity was measured in a sidearm flask in order to maintain a constant surface volume ratio and thus assure the same degree of oxygenation, using a Rlett-Sumnerson colorimeter with a \#54 or 非66 filter. Cell size did not change appreciably until the culture reached the stationary growth phase, thus making this method a valid measure of cell number for Klett readings between 20 to 60 for the $\# 54$ filter and \#66 filter.

The total amount of cellular material was estimated by measuring the number of viable bacterial cells and/or by measuring bacterial protein. A plot of turbialy vs number of viable cells per ml culture (Figure 1) and turbidity vs micrograms protein per $\mathrm{ml}$ of culture (Figure 2) shows that turbidity is proportional to both number of viable cells per $m l$ culture and protein per $m l$ culture over the range normally encountered in these experiments.

Mieasurement of Arsenite Oxidation by Respirometry

Thunberg Method. Cell free suspensions were prepared by sonication of a cell suspenston (approximately 0.5 grams cell paste per m1) using a Bronwill Blosonik III. Heat was dissipated by immersing the metal tube contalning the cells in an ice-salt bath. The cells were treated for 30 second intervals until the paste took on a "metallic" quality (usually 1 1/2 minutes). The suspension was then diluted with $0.1 \mathrm{M}$ phosphate buffer, $\mathrm{pH} 6.6$ to 6.8 to give the final desired concentration.

Conventional Thumberg techniques (Umbreit et al., 1957) for the estimation of anaerobic arsenite oxidation were used with 2,6 dichloro- 


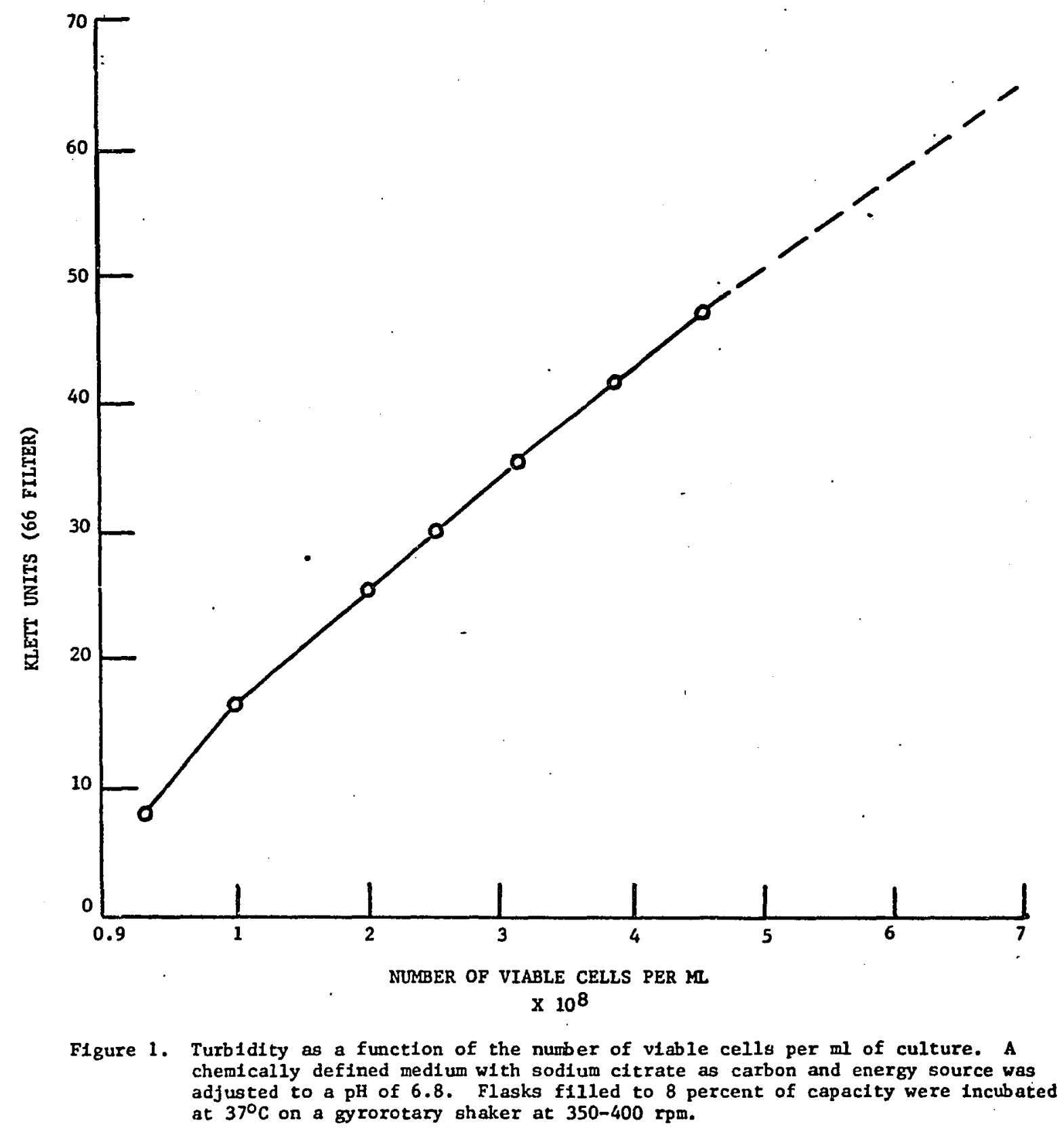




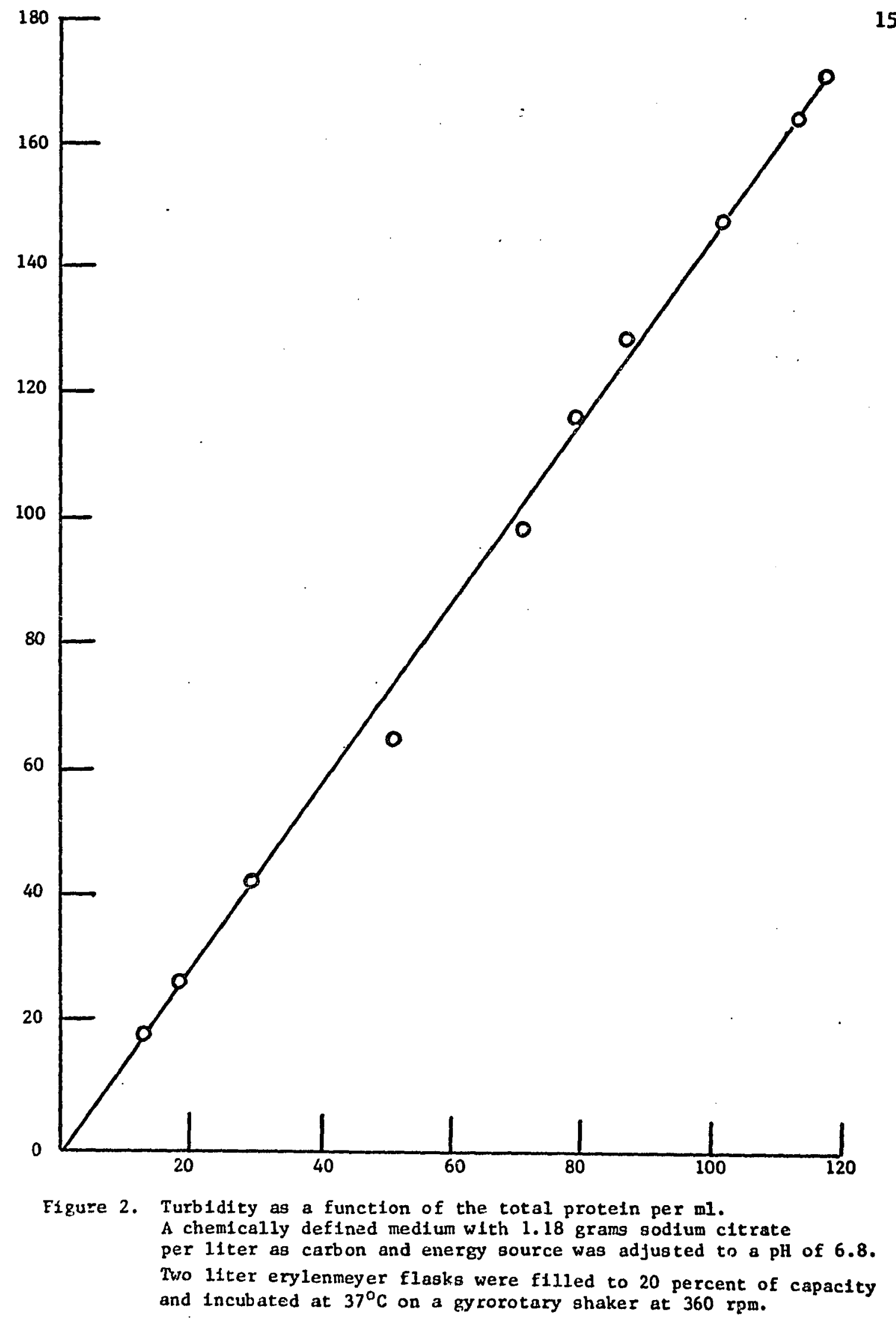


phenolindophenol as electron acceptor. The absorption spectrum for oxidized and reduced 2,6 dichlorophenolindophenol in 0.1 phosphate buffer, pH 6.8 is shown in Figure 3. Figure 4 shows that the absorbance for 2,6 dichlorophenolindophenol in $0.1 \mathrm{M}$ phosphate buffer, $\mathrm{pH} 6.8$, is proportional to dye concentration over the range used experimentally and that given a pathlength of $1.25 \mathrm{~cm}$, the molar extinction coefficient, $\Sigma$, at $590 \mathrm{~min}$ is $1.4 \times 10^{-3}$ liter $\mathrm{cm}^{-1}$ mole-1. Reduction of the dye was followed using a Bausch and Lomb Spectronic 20 colorimeter at room temperature. A blak containing reduced dye, a control containing no arsenite, and another a second control containing boiled extract were always included. (0xidized 2,6 dichlorophenolindophenol inhibited the arsenite oxidizing activity if allowed to stand for longer than I hour with the extract.)

Oxygen Probe Method. A biological oxygen monitor (YSI Model 53, Yellow Springs Instruments) was used for the estimation of oxygen uptake. Measurements were made using $3 \mathrm{ml}$ samples according to directions accompanying the instrument. The probe was standardized at zero oxygen after addition of excess sodium hydrosulfite and at 100 percent oxygen usfing atr-saturated buffer. The solubility of oxygen in oxygen-saturated solutions (assuming that 21 percent of air is oxygen) was calculated from the solubility of oxygen in oxygen-saturated solutions found In the 1lterature (Umbrelt et al., 1957). Values could not be obtained experimentally for phosphate buffer by the Winkler method (Welsh et al., 1968) because of the precipitacion of metal phosphates. Therefore, the assumption was made that the difference in the $\mathrm{ml} \mathrm{O}_{2} / \mathrm{ml}$ Ringer's solution (ionic strength $=0.18$ ) and the $\mathrm{ml} 0_{2} / \mathrm{ml} 0.1 \mathrm{M}$ phosphate buffer 


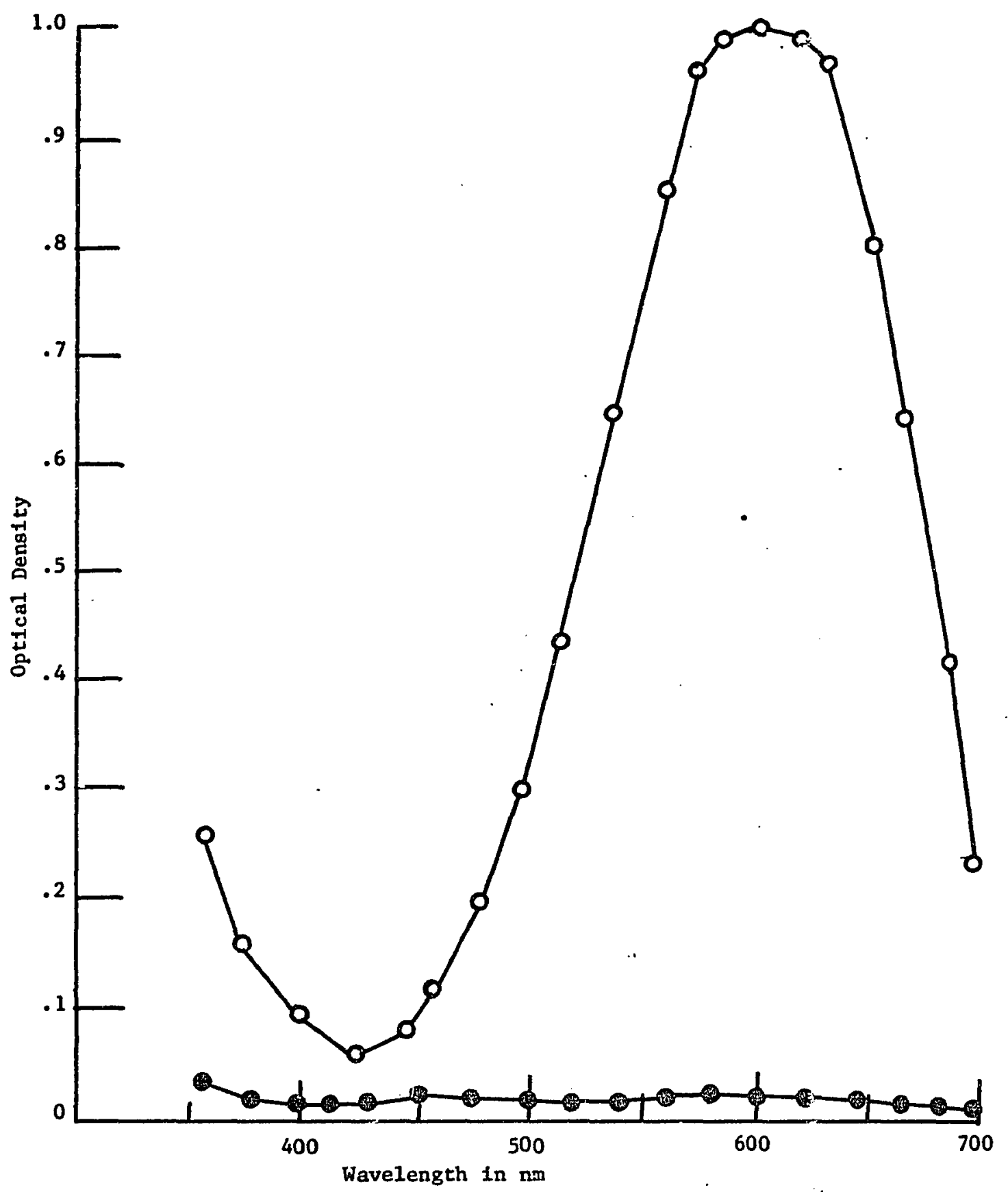

Figure 3. Absorption spectrum for 2,6 dichlorophenolindophencl in 0.1 phosphate bux́-:I pH 6.8 .

0 - 0 - 0 , oxidized form; - - - 0 , reduced form 


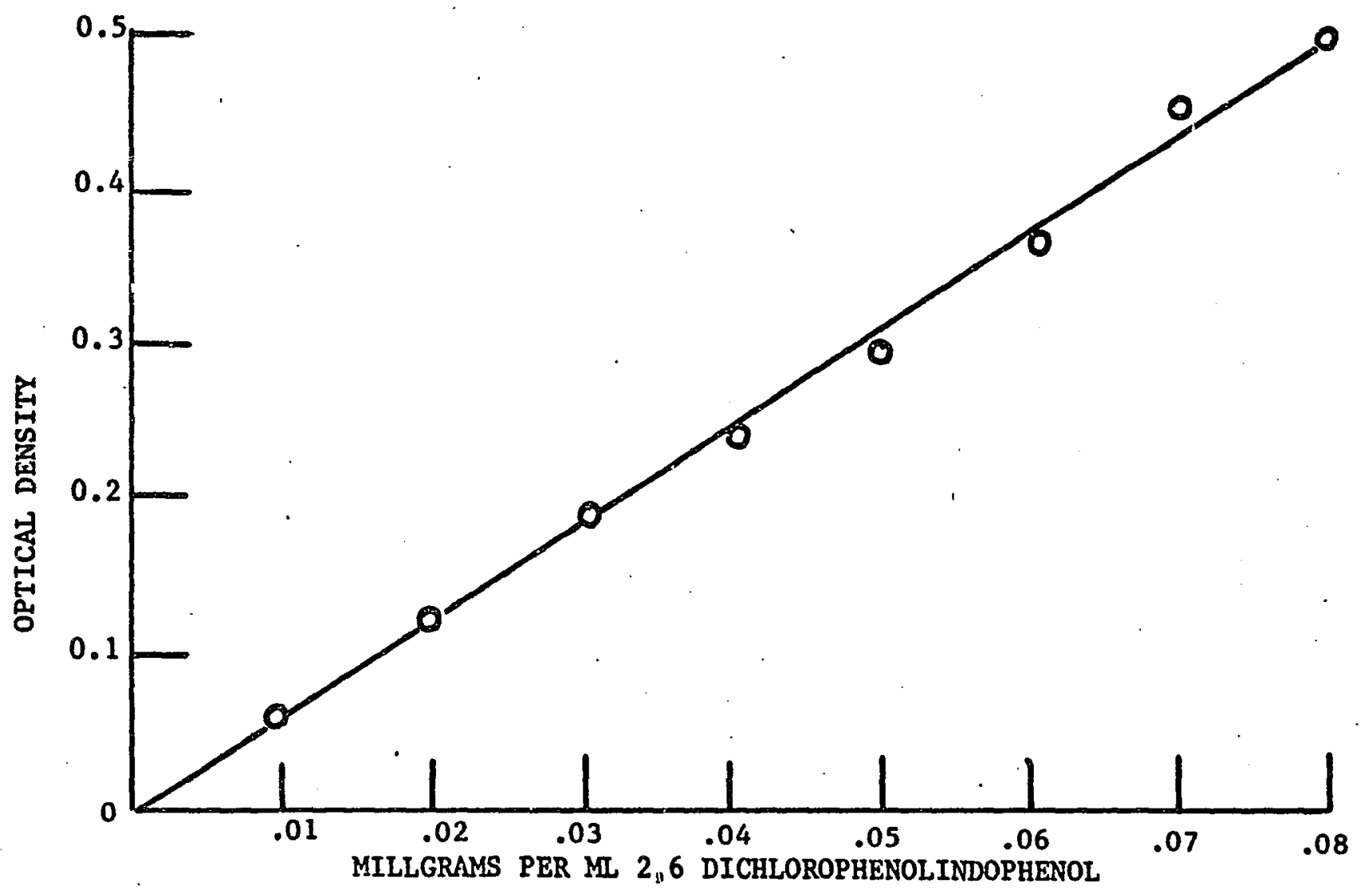

Figure 4. Optical density at $590 \mathrm{~nm}$ as a function of the concentration of 2,6 dichlorophenolindophenol in $0.1 \mathrm{M}$ phosphate buffer, $\mathrm{pH} 6.8$.

$\stackrel{\infty}{\infty}$ 
(1onic strength $=0.35)$ was not significant. For example, oxygen-saturated Ringer's solution at $25^{\circ} \mathrm{C}$ and 1 atmosphere pressure contains $0.0285 \mathrm{ml}$ oxygen per ml fluid or if air-saturated $0.0285 \times 0.21=$ $0.00599 \mathrm{ml}$ oxygen per ml Ringers. Unless otherwise stated the reaction vials always contained $3 \mathrm{ml}$ of fluld; thus Ringer's solution contained 18 microliters oxygen per vial or 0.801 micromoles oxygen per vial. A typical recorder trace for the addition of 0.3 micromoles arsenite resulted in the consumption of 19 percent of the oxygen in the vial or $\frac{0.801}{0.3} \frac{\text { matcromoles oxygen } \times 0.19}{\mathrm{~m}_{\text {L }} \text { cromoles arsenite }}=0.5 \mathrm{micromoles}$ oxygen taken up per umole of arsenite oxidized. (It should be noted that this is not the maximum rate of oxygen consumption for this organism but merely an example of the technique.)

Knowing the amount of arsenite added, the rate of the reastion can be obtained by determining the time required from arsenite addition to the return to the endogenous trace. Usually, however, the rate of arsentte oxidation by aerated, washed suspensions of intact cells was obtained from the slope of the trace. The rate could not be determined from Initial rates (about 20 percent of the total oxygen uptake) because under the conditions of these experiments, the trace was irregular for up to 60 seconds after addition of a reagent to the reaction vessel. Rates were calculated from the percent oxygen consumed between the second and third minute of the reaction; the trace was always linear in this period.

The reaction rate could be adjusted by increasing or decreasing the number of organisms present in the reaction mixture indicating that the rate of uxygen consumption was proportional to enzyme concentration. 
Thus, as conditions changed (sich as culture age), the rate could be brought into the experimental range by altering the number of cells present in the vial.

Isolation of Bacteria

A 250 ml sample of raw sewage taken July, 1971, from a grlt chamber at Ithaca, New York, was dosed with 1000 micrograms sodium arsenite per ml and incubated at $22^{\circ} \mathrm{C}$ on a rotary shaker for three weeks. The mouth of the flask was covered with saran wrap to prevent evaporation but allow gas exchange. Five ml samples were withdrawn from the flask each day for three weeks, centrifuged to remove the sediment and the supernatants were decanted and frozen for later analysis. The samples were analyzed for total arsenic, arsenite and arsenate.

When arsenite was no longer detectable in the enrichment, Hersheys' medium (Meynell and Meynell, 1965) containing 0.1 percent glucose, 1.5 percent agar and $0.02 \mathrm{M}$ sodium arsenite was prepared for isolation of arsenite oxidizing bacteria. This medium was used with no additions, with the addition of 0.1 percent vitamin-free casamino acids, or supplemental with 0.3 percent yeast extract. Samples from the sewage suspension containing the putative arsenite oxidizing microbes were diluted $1: 10^{-6}$ using $1: 10$ dilutions into sterile water. Aliquots of $0.1 \mathrm{ml}$ of each of the dilutions were spread across the surface of various types of isolation media with a bent glass rod in duplicate and incubated for 2 days at $30^{\circ} \mathrm{C}$ in darkness. Individual colonies were inoculated into tubes containing $10 \mathrm{ml}$ of the appropriate Hersheys' broth and incubated 3 days at $30^{\circ} \mathrm{C}$ in darkness with no aeration. The disappearance of arsenite was determined by lodometric titration after 3 days 
growth. Bacteria from twes in which arsenite concentrations were decreased by 3 days were isolated and purified using standard bacteriological methods (Society of American Bacteriologists Manual, 1957).

\section{Identification Techniaues}

Supplements.

I. Vitamin Supplement. Stock solution I consisted of 0.025 grams pyridoxal hydrochlorlde, 0.100 grams thiamine, 0.100 grams calcium panothenate, 0.100 grams riboflavin, 0.100 grams niacin, 0.050 grams p-aminobenzoate, 0.200 grams pyrodoxine hydrochloride and 200 micrograms vitamin $B_{12}$ dissolved in distilled water to make one liter. This mixture was stored in $100 \mathrm{ml}$ aliquots in the freezer.

Stock solution II consisted of 500 micrograms biotin and 25 milligrams folic acid dissolved in distilled water to give a final volume of $200 \mathrm{ml}$. This mixture was stored in $10 \mathrm{ml}$ aliquots in the freezer. Ten $\mathrm{ml}$ of solution $\mathrm{I}$ and $2 \mathrm{ml}$ of solution II per liter were added to supplement a basal salts medium.

II. Mineral Supplement. The mineral supplement consisted of 4.0 grams $\mathrm{MgSO}_{4} \cdot 7 \mathrm{H}_{2} \mathrm{O}, 0.5 \mathrm{gram} \mathrm{MnSO}_{4} \cdot \mathrm{H}_{2} \mathrm{O}, 0.05$ gram $\mathrm{FeSO}_{4} \cdot 7 \mathrm{H}_{2} \mathrm{O}, 0.1$ gram $\mathrm{CaCl}_{2} \cdot \mathrm{H}_{2} \mathrm{O}, 0.1$ gram $\mathrm{Na}_{2} \mathrm{MoO}_{4}$ and $0.052 \mathrm{ml}$ concentrated sulfuric acid dissoived in distilled water to make $100 \mathrm{ml}$ of solution. Ten $\mathrm{ml}$ of this mixture were added per liter to supplement a basal salts medium.

III. Casamino Acid Supplement. Varying amounts of vitamin free casein hydrolysate were added to supplement the basal salts medium where needed. 


\section{Standard Media.}

I. Basal Salts Medium (BSM). Unless otherwise noted, basal salts medium contained 1.5 grans sodium ammonium phosphate, $\left(\mathrm{NaNH}_{4} \mathrm{HPO}_{4}\right), 1.0$ grams monobasic potassium phosphate $\left(\mathrm{KH}_{2} \mathrm{PO}_{4}\right), 0.4$ grams magnesium sulfate $\left(\mathrm{MgSO}_{4} \cdot 7 \mathrm{H}_{2} \mathrm{O}\right)$, an appropriate organic carbon and energy source and distilled water to make one liter of solution. The $\mathrm{pH}$ was adjusted to 6.8 with concentrated hydrochloric or sulfuric acid. Agar medium was prepared by adding 15 grams per liter agar to the liquid media.

II. Chemically Defined Medium (CDM) - Unless otherwise stated, chemically defined medium was composed of 1 liter of basal salts medium, $10 \mathrm{ml}$ of vitamin supplment $\mathrm{I}, 2 \mathrm{ml}$ of vitamin supplment II, and 0.05 grams casamino acid supplement, and a utilizable carbon source. III. Nutrient Broth Yeast Extract (NMYE). This was prepared by adding 3 grams yeast extract and 8 grams Difco nutrient broth to distilled water to make one liter. An agar medium was prepared by adding 15 grams per liter agax to the liquid medium.

Screening of Organic Compounds as Sources of Carbon and Energy for Growth. Tests for growth to see if various carbon sources could serve as sole source of carbon and energy were made on CDM agar plates containing ten grams per liter of the carbon source to be tested. The carbohydrates were filter sterilized and added aseptically to the sterile agar medium. Amino acids were autoclaved separately and added to the sterile mineral base agar. Thirty-four cultures were spotted on duplicate plates for each carbon source. One plate from each duplicate was placed in a BBL gas-pak anaeroblc jar to test for anaerobic growth. The 
anaerobic jar and the second plates (maintained under aerobic conditions) were incubated at $37^{\circ} \mathrm{C}$ for 3 days and then removed to room temperature for an additional eleven days. The cultures were then examined for growth by comparing growth on the plate containing the carbon source with a plate spotted and incubated in the same way containing no carbon source. Denitrification. The method of Stanier et al. (1966) was used except that BSM supplemented with 0.5 percent yeast extract, 1 percent $\mathrm{KMO}_{3}$ and 0.1 percent Ion agar (Oxoid) replaced their supplemented (YE) medium.

Nitrate Reduction. This test was performed according to the procedure given in the Difco Manual (1953), except that two tubes, one containing nitrate broth only and the other containing $0.01 \mathrm{M}$ arsenite in nitrate broth, were inoculated and incubated at $37^{\circ} \mathrm{C}$ for exactly 24 hours. The appropriate tubes were tested for the disappearance of arsenite by iodometric titration.

Determination of Pigment Production. The method of Stanier et al. (1966) was used. Cultures were examined for pigmentation at 1, 2, 3, 7, and 14 days after inciulation. Growth of cultures on King B medium was examined under long wave ultraviolet light for determination of fluorescent pigments.

Biochemical Characters.

I. Cleavage of Diphenols. Cleavage of diphenols was determined by the method outlined by Holding and Collee (1971). A culture grown in NBYE medium was tested as a control to insure that the observed activity had been specifically Induced by growth on sodium para-hydroxybenzoic acid. 
II. Arginlne Dihydrolase. Assay of the arginine dihydrolase system was performed according to the method of Thornley (1960). Using this method each strain was inoculated by stabbing to the bottom of the tube with a needle and immediately seallng the tube with sterile vaspar. The tubes were incubated for 3 days at $37^{\circ} \mathrm{C}$ and an additional 11 days at room temperature. An alkaline pH change (medium turns bright pink) was recorded as positive; no change or an acid reaction was recorded as negative.

III. Oxidase. The oxidase test using $\mathrm{N}, \mathrm{N}$-dimethyl-paraphenylenediamine resulted in oxidase positive strains turning purple within a few seconds when a drop of the reagent was placed on a colony. This test apparently detects the presence of cytochrome $c$ in bacteria (Stanier et al., 1966).

IV. Catalase. A sample of each strain from an NBYE agar spot plate was suspended in $1.0 \mathrm{ml}$ of 3 percent hydrogen peroxide. The rapid formation of bubbles of gas vas recorded as positive.

V. Production of Extracellular Enzymes.

A. Proteolytic Activity. (1). Gelatin Liquefaction. Difco Nutrient Gelatin was prepared according to the labei instructions. The tubes were incubated for 14 days at $32^{\circ} \mathrm{C}$. After Incubation the Inoculated tubes and a control tube were cooled in an ice bath to determine If the gelatin had been 1lquefied. (2). Casein Digestion. Bacto Litmus Milk was prepared according to label instructions. Casein digestion and/or reduction of litmus was determined after 14 days incubation at $32^{\circ} \mathrm{C}$.

B. Starch and glycogen hydrolysis. Strains were 
spotted on BSM agar supplemented with 0.5 percent yeast extract and 0.2 percent soluble starch or glycogen. The plates were flooded with Lugol's solution after Incubation at room temperature for 14 days; those strains which showed clear areas around the colony were scored positive.

Cytological Observations. A young culture of each strain, grown In NBYE, was examined for gram reaction, motility (hanging drop method), and presence and distribution of flagella using Gray's stain (Society of American Bacteriologists Manual, 1957). In addition each arrain was examined for flagella using the electron microscope.

Each 1solate was also grown in a medium containing 5 grams per liter sodium succinate as the sole source of carbon and energy and exanlned after 72 hours incubation at $37^{\circ} \mathrm{C}$, when growth presumably had become nitrogen limited (Stanier et al., 1966). Strains containing extensive intracellular deposits of poly-beta-hydroxybutyrate (a refractile substance readily observable by phase contrast microscopy of wet mounts) were recorded as positive.

Temperature Range. Cultures in tubes containing $5 \mathrm{ml}$ of NBYE were Incubated for 7 days at $4^{\circ} \mathrm{C}, 39^{\circ} \mathrm{C}$ and $41^{\circ} \mathrm{C}$. If growth failed to occur after 7 days of incubation, the culture was reincubated for an additional 7 days at room temperature to confirm successful inoculation. Stocking. Many of the strains were heterogeneous in regard to colony size when streaked on NBYE; to check for purity before transferring to fresh maintenance medium during the tenure of this study. A mlxture of small and larger colontes were commonly found from a single 1solate. Since the orfginal 1solate was the larger colony in all cases, these were assumed to represent the w11d-type form and they were 
selected for the stock cultures. For stocking cultures were grown in NBYE, centrifuged and resuspended in distilled water where they were maintained at room temperature up to six months between transfers.

Determination of Conditions for Opt1mum Growth Rate and Cell Yield

General Experimental Design. The environmental factors most strongly affecting growth of any organisms are temperature, aeration, $\mathrm{pH}$ and nutrition. For each experiment all these factors except the one under study were held at the following standard values: temperature, $37^{\circ} \mathrm{C}$; aeration by gyrotory shaker (New Brunswick Scientific Company, model number $\mathrm{G}-25$ ) at setting 10 , which was approximately $360 \mathrm{rpm}$; $\mathrm{pH}$, 6.8; medium, the previously described chemically defined medium (CDM) with $0.01 M$ carbon and energy source (usually sodium citrate or glutamate).

Except as noted, in each experiment a 100-150 ml aliquot of an overnight culture of YE56 (grown under the experimental conditions) wias diluted to $1000 \mathrm{ml}$ with fresh medium (incubated before inoculation under the same experimental conditions). Under these circumstances the diluted cultures continued to grow logarithmically. Turbidity was estimated by hourly monitoring optical density at $660 \mathrm{~nm}$ with a Bausch and Lomb Spectronic 20 or in the Klett-Summerson colorimeter using a \#66 filter. In each experiment (except those at the least suitable temperatures) growth was followed until one hour after the culture reached stationary phase. The doubling times under varfous conditions were calculated from plots of the data.

Temperature. A culture grown overnight under standard conditions 
was diluted as outlined above and $50 \mathrm{ml}$ aliquots of the diluted preparatIon were dispensed into one liter flasks. The large flasks were used in order to maximize the surface to volume ratio to provide for aeration, since the cultures in this serles were grown in water baths without mechanical agitation. The growth temperatures tested were $22^{\circ} \mathrm{C}, 27^{\circ} \mathrm{C}$, $32^{\circ} \mathrm{C}, 37^{\circ} \mathrm{C}$, and $42^{\circ} \mathrm{C}$.

Aeration. For the present investigation the overnight culture was grown under standard conditions. After dilution of the overnight culture, aliquots of $50,75,100,125$, and $150 \mathrm{ml}$ were dispensed into 500 ml Rlett flasks in triplicate. One set of flasks was incubated at $37^{\circ} \mathrm{C}$ at $320 \mathrm{rpm}, 360 \mathrm{rpm}$, or $400 \mathrm{rpm}$.

pH. One hundred ml aliquots of medium were placed in 500 ml sidearm flasks and the $\mathrm{pH}$ of each was adjusted. The flasks were autoclaved and then placed in a rotary shaker incubator at $37^{\circ} \mathrm{C}$ and shaken uninoculated for 16 hours. Ten $\mathrm{ml}$ allquots of an overnight culture grown under standard conditions were filtered through a 0.45 micron millipore filter and the filter disc obtained from one $10 \mathrm{ml}$ sample was placed In each flask as an inoculum. The growth was estimated hourly.

Phosphate $b u f f e r s$ were used for the $\mathrm{pH}$ range 5.7 through 8.0 ; for media adjusted to $\mathrm{pH} 8.0$ through 10.0 borate buffer was used. To Investigate the possibility that growth was affected by the chemical composition of the buffer 1tself, both phosphate and phthalate containing medla were used at $\mathrm{pH} 4.0$ through 6.0 and both phosphate and borate containing medla were used at $\mathrm{pH} 8.0$ through 10.0 .

In a varlation of this experiment, $0.01 \mathrm{M}$ sodium arsenite was added to the medium prior to $\mathrm{pH}$ adjustment. Flasks of media at the 
extremes of the $\mathrm{pH}$ range were inoculated 12 hours earlier than the remainder of the cultures. When the culture reached stationary phase, the media was neutralized with sodium bicarbonate before the percent arsenite oxidized was estimated by iodometric titration.

Nutrition.

I. Vitamins. Ten $m 1$ aliquots of an overnight culture grown under standard conditions were filtered through 0.45 micron millipore filters. A filter disc with the organisms from one $10 \mathrm{ml}$ culture sample was added to each of six $250 \mathrm{ml}$ erlenmeyer flasks containing 50 ml of warmed and aerated medium of standard composition except for the Vitamin supplement which was present at $2,4,6,8,10$, or $12 \mathrm{ml}$ per liter ( 2 parts solution $I$ and 1 part solution II).

II. Amino acids. The above experiment was repeated using the standard medium minus casamino acids and adding acid hydrolyzed casein to give a final concentration of $0,10,30,50,100,150$, or 200 micrograms per $m l$. A second serles of experiments was performed in which varying amounts of aspartic and glutamic acids (totaling 100 micrograms amino actd per $\mathrm{ml}$ ) were substitued for acid hydrolyzed casein. III. Carbon and energy source. The basic experiment was performed again usirg the standard medium but with varying amounts of sodium citrate. One hundred $\mathrm{ml}$ of $\mathrm{CDM}$ in $500 \mathrm{ml}$ Klett flasks contained $0.05,0.1,0.5,2.5,3.75$, or 5.0 grams per 11ter of sodium citrate. IV. Determination of molar growth yields. Flasks containIng CDM were inoculated from an overnight culture which had been grown with a IIniting amount of carbon source. Under these circunstances logarithmic growth is not interrupted. Determinations of molar growth 
ylelds under aerobic conditions were performed in the CDM with the same compound serving as sole source of carbon and energy. Since prior experfments had shown that the carbon and energy source was the growth IImiting factor, the energy source was assumed to be completely consumed. The proportion of the substrate that was assimilated was determined from the dry weight of the cells with the assumption that the amount of carbon in the cells was 40 percent of the dry weight. Growth was followed by measuring the optical density of samples taken at intervals.

Determination of Conditions for Maximum Arsenite Oxidation

General Experimental Design, A culture of Pseudomonas actdovoransarsenoxydans YE56 was grown at $\mathrm{pH} 6.8$ and made up as washed cell suspensions in the same buffer. Turbidity and total protein were both used to estimate the amount of cellular substance. Arsenite oxidation was measured by respirometry, and in some cases by iodometric titration. Activities are expressed as micromoles arsenite oxidized per hour per milligram protein or if treatments were being compared, micromoles arsenite oxidized per hour. Maximum arsen: :e oxidation was defined as that particular condition where a washed suspension of cells displayed Its highest activity. 
RESULTS

Separation of Arsenite and Arsenate

Thin Layer Chromatography. As shown in Table V, arsenite and arsenate could be separated by each solvent system used and, although not quantitative, this method could detect as little as one microgram of arsenic. However, in every solvent system, arsenate streaked badly; and arsenite and arsenate were not widely separated, e.g. Figure 5. In addition both compounds were detectable with ammonium molybdate/stannous chlorfde spray; the colors were very similar. As described under Materials and Methods, definitive separation could be made if the chromatograms were first treated with iodine vapors. Figure 5A shows the appearance of a chromatogram after exposure to $I_{2}$ vapors; Figure $5 B$ shows the same chromatogram after spraying with molybdate-stannous chloride.

Paper Chromatography. Descending chromatography systems gave better separations than ascending techniques. The data obtained from two descending systems is compared in Table VI. Arsenite was detected with lodine vapors, and the spot colors for arsenite, arsenate and phosphate were the same as those recorded in Table V. Although differences in $R_{f}$ 's were wide with this method, as shown in Figure 6 , it was not used because of the long development time.

It was found that components present in the media retarded the movement of both organic and inorganic arsenicals in both thin layer and paper chromatography. Therefore, reference standards were dissolved In medium and tested to determine the influence of the medium 
TABLE V

SEPARATION OF ARSENICALS AND PHOSPHATE BY THIN LAYER CHROMATOGRAPHY

\begin{tabular}{|c|c|c|c|}
\hline & \multicolumn{3}{|c|}{ SPOT COLOR } \\
\hline & $\mathbf{R}_{\mathbf{f}}$ & $\begin{array}{l}\text { IODINE } \\
\text { VAPORS }\end{array}$ & $\begin{array}{l}\text { AMMONIUM MOLYBDATE \& } \\
\text { STANNOUS CHLORIDE }\end{array}$ \\
\hline \multicolumn{4}{|l|}{ Methanol: Ammonia:TCA: Water } \\
\hline Sodium arsenite & 0.30 & Ye11ow & Gray Blue \\
\hline Sodium arsenate & 0.35 & None & Dark Blue \\
\hline Monosodium methylarsonic acid & 0.69 & None & White \\
\hline Dimethylarsinic actd & 0.72 & None & White \\
\hline \multicolumn{4}{|l|}{ Butano1: Acet1c Acld:Water } \\
\hline Sodium arsenite & 0.56 & Yellow & Gray Blue \\
\hline Sodium arsenate & 0.44 & None & Dark Blue \\
\hline Sodium-potassium phosphate & 0 & None & Dark Blue \\
\hline \multicolumn{4}{|l|}{ Propano1-1: Ammonia } \\
\hline Sodium arsentte & 0.39 & Yellow & Gray Blue \\
\hline Sodium arsenate & 0.56 & None & Dark Blue \\
\hline Sodium-potassium phosphate & 0 & None & Dark Blue \\
\hline
\end{tabular}

Arsenate streaked in a11 solvent systems 
Graph A

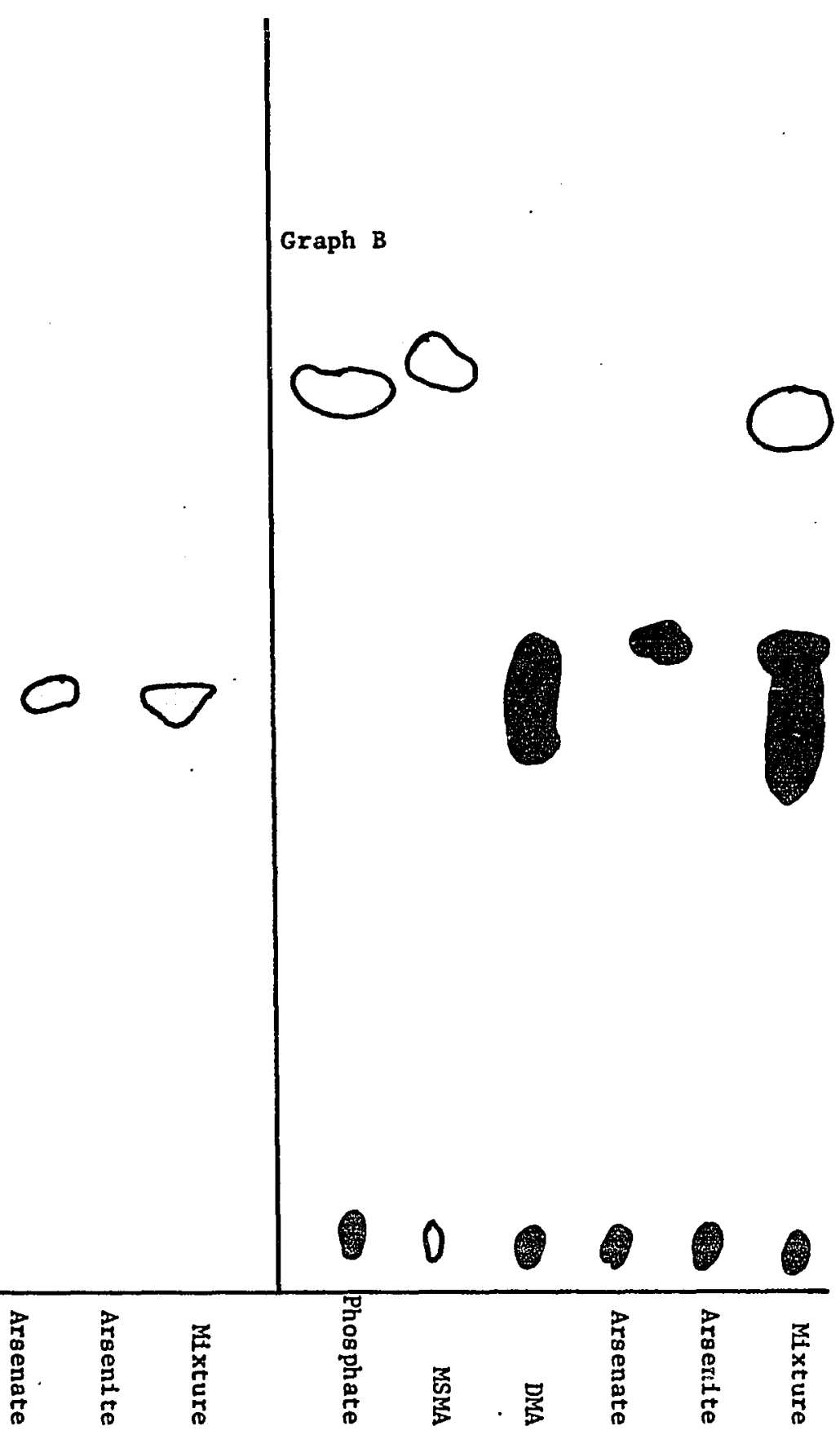

Figure 5. Typical thin layer chromatogram run in methanol:ammonla: 10\% trichloroacetic acid:water. Ten micrograms of dimethyl arsinic acid (DMA) and monosodium methylarsonic acid while 5 micrograms of sodium arsenite and sodium arsenate all in $0.1 \mathrm{M}$ phosphate buffer were spotted. 
TABLE VI

SEPARATION OF ARSENICALS AND PHOSPHATE BY PAPER CHROMATOGRAPHY

\begin{tabular}{l|cr}
\hline \multirow{2}{*}{ COMPOUND } & & $\mathrm{R}_{\mathrm{f}}$ \\
\cline { 2 - 3 } Arsenite & AMMONIUM ACETATE:ETHANOL & BUTANOL-1 :ACETIC ACID:WATER \\
Arsenate & 0.47 & 0.44 \\
Phosphate & 0.52 & 0.17 \\
Monosodium methylarsonic acid & 0.47 & 0.01 \\
Dimethyl arsinic acid & 0.55 & Not run \\
\end{tabular}



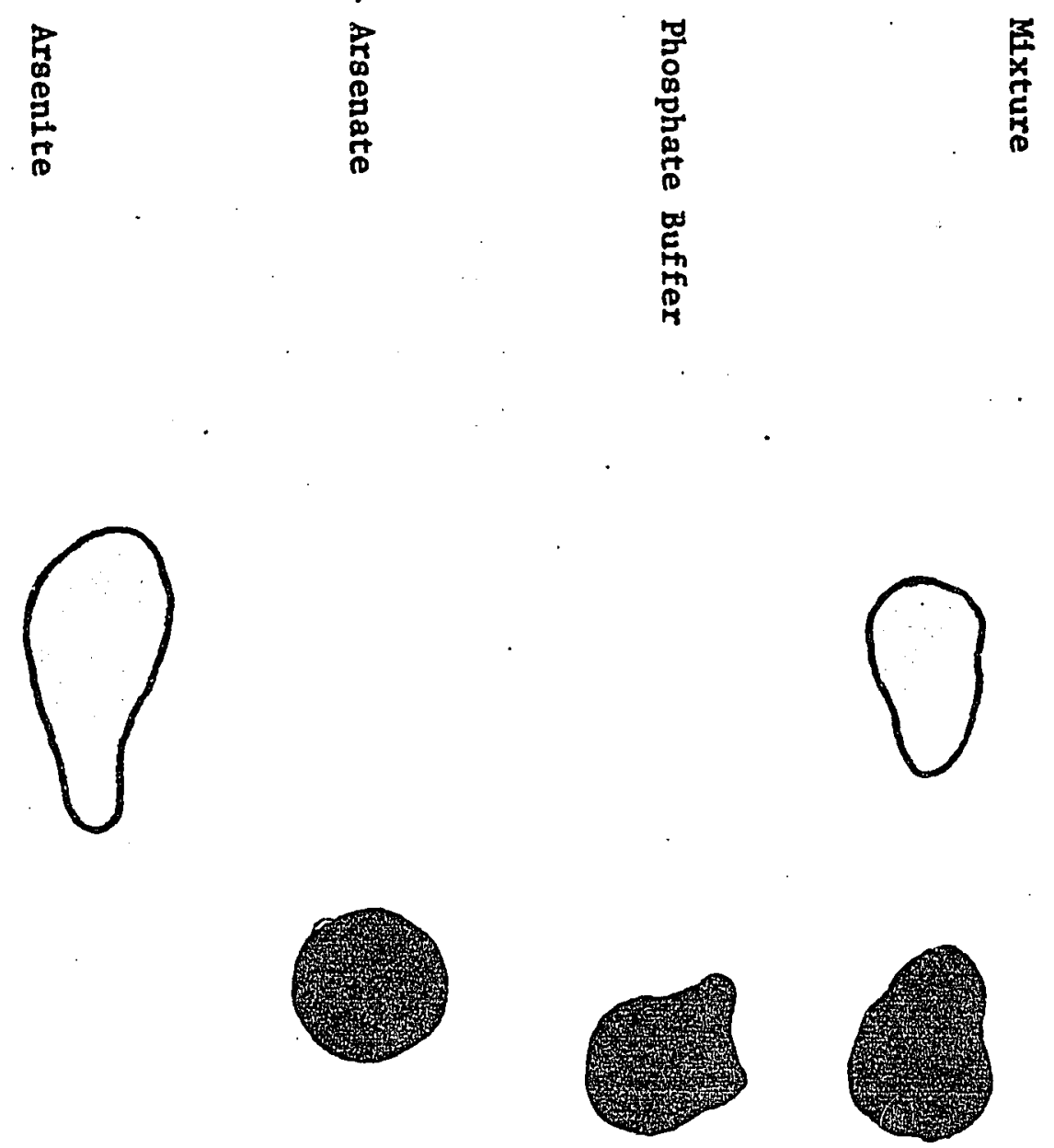

Figure 6. A typical descending paper chromatogram of $20 \mathrm{mlcrogram}$ sodium arsenite, 20 micrograms sodium arsenate and $20 \mathrm{micro-}$ 1iters of $0.1 \mathrm{M}$ phosphate buffer, $\mathrm{pH} 6.8$ developed overnight In n-butanol:acetic acid:water. 
upon $R_{f}$ for arsenicals.

Isolation

Each day a $5 \mathrm{ml}$ alfquot of the enxiched sewage was titrated for arsente in triplicate with standard lodine solution. In addition a ten microliter aliquot of each sample was tested for total arsenic by the silver diethyldithiocarbamate colorimetric method. The total quantity of arsenic in the flask remained constant in all the samples for a period of 17 days.

Since the total quantity of arsentc did not change and since a flask containing sewage without arsenite maintalned a constant amount of titratable reducing substance during the expertment, the long lag perlod before the decrease in the amount of lodine required to titrate the dafly samples changed drastlcally, Indicated that the ability to oxddize arsenite had occurred through a genetic mutation, Figure 7. Disappearance of arsenite with time was also noted when samples were analyzed by TLC. Figure 8 shows that the daily decrease in arsenite was correlated with a corresponding increase of arsenate.

\section{Growth Factor Requirements}

The majority of Pseudomonas species will grow well in a mineral salts medium in which the source of carbon is c1trate or other simple organic compound. Only a few spectes require amino nitrogen or growth factors (Skerman, 1967). Since some strains of arsenite oxidizing pseudomonads isolated on plates supplemented with yeast extract or casamino ac1ds would not grow in BSM without these compounds, it was necessary to determine the minimal nutritional requirements of these 


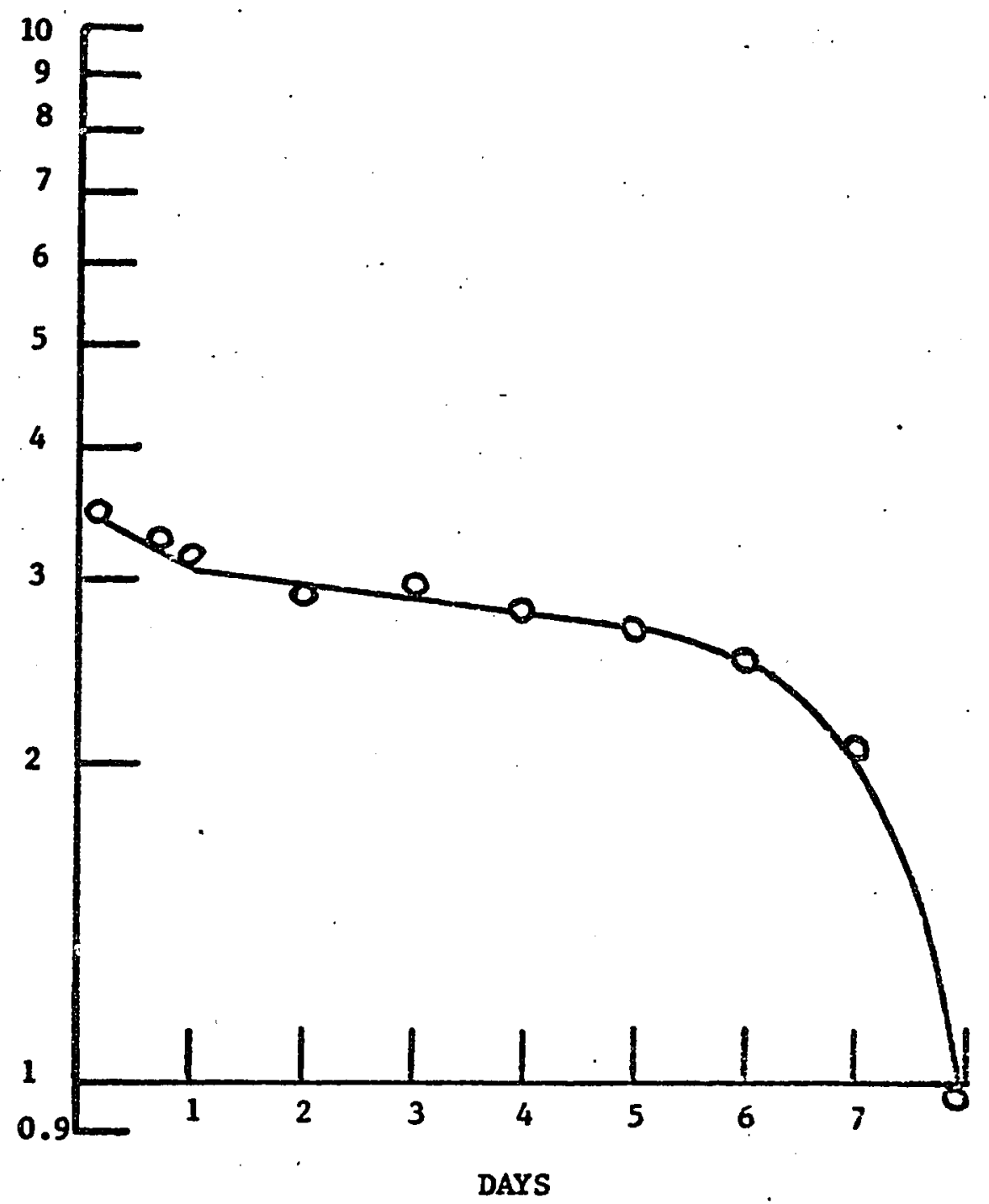

Figure 7. Disappearance of sodium arsenite from sewage with time as measured by lodometric titration. 


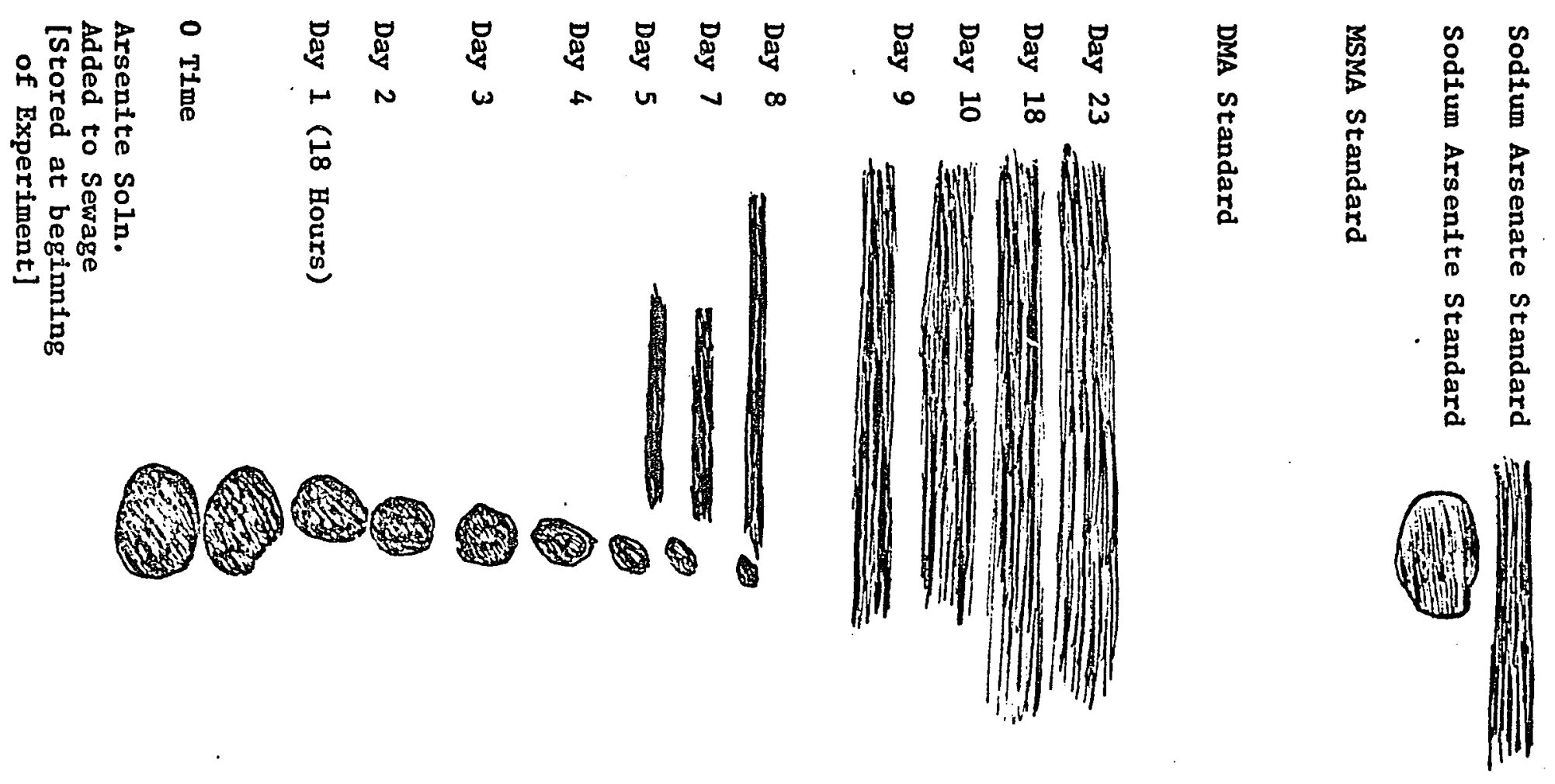

Figure 8. Thin Layer Chromatography. Representation of Standards and dally samples of enriched sewage. $20 \times 20 \mathrm{~cm}$ plates were layered with silica gel F-254; $10 \mu \mathrm{g}$ of the standard in water or $1.0 \mathrm{\mu g}$ of the dosed sewage was applied. The plates were developed in methano1:Ammonia:TCA:Water. Spots were visualized by exposure to lodine vapors followed by spraying first with ammontum molybdate and then stannous chloride. DMA = DimethylArsinic acid (Cacodylic Acid); MSMA = Monosodium Methanearsonic acid. 
Ye56

YesB

Ye79

Ye86
CA4

CAB

CA1O

CAll

CA27

CA38

CA45.

CA45b

CAST

CA7?

GI

C6.

G7

G14

G27

631
633

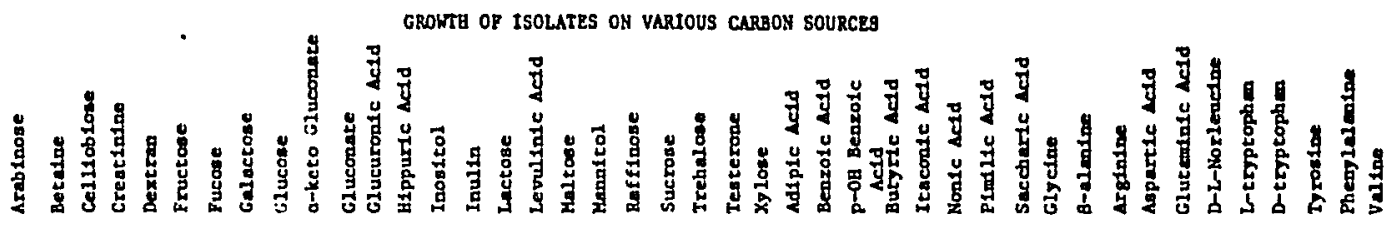

$0000000000000++000000000000000+0++0++0++++++++$ $0000000000000+0000000000000000+0+++0++0++++++0+++$ $+00++++++++0+0+0+++++0+00+000000++++000++t$ $++00++0+++++0+0+0++t++0+00+000++0++++000+++$

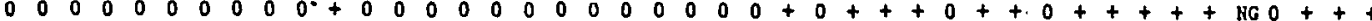

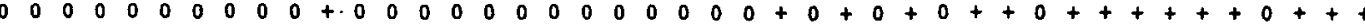

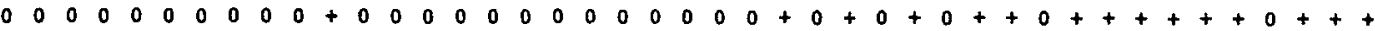

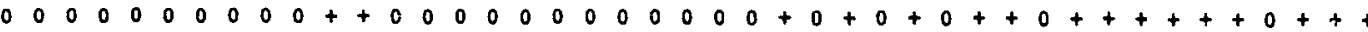
$0000000000+0000000000000+0+0+0+++++++++$

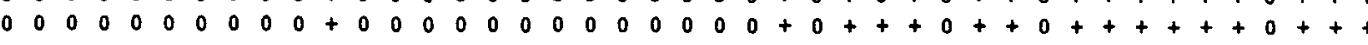

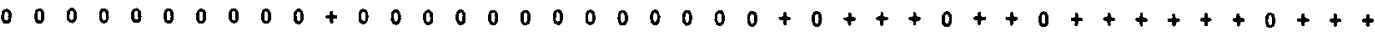

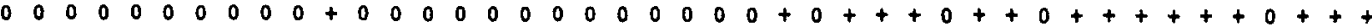
$0000000000000+0000000000000+t++++0+t+$

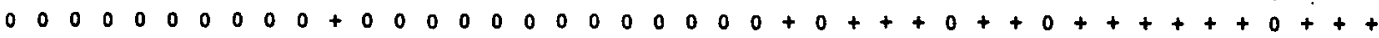

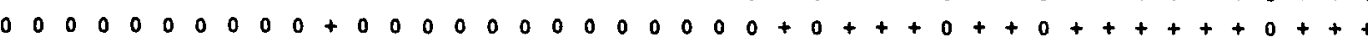

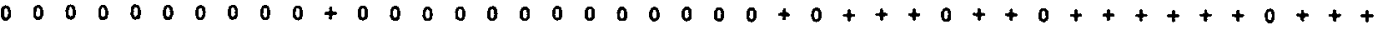

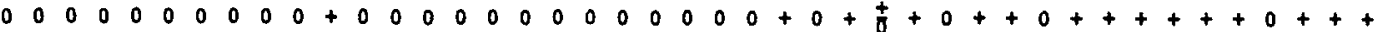
$000000000000+0000000000000000+0+t+++++0+++$ $0000+000+0+00000000000000++0+++0++0++++++0+++$ $++00++0++0+00+0+0++0++0+00+000000++++000+++$ $++00++++++++0+0+0+++++0+00+0000000++++000+++$

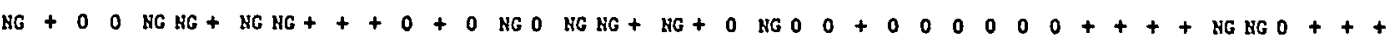

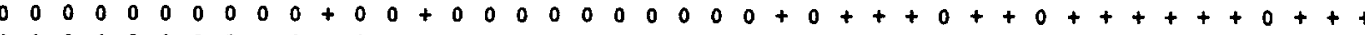

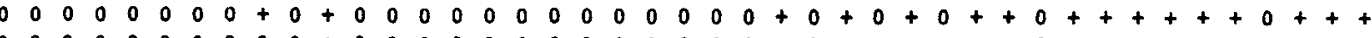

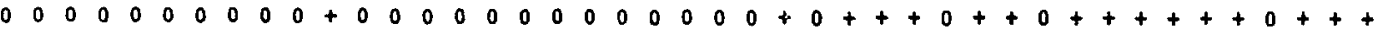

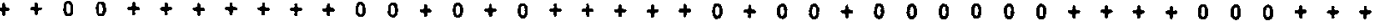
$000000000000+000000+000000+0+++0++0++++++0+++$ $++00++++++++0+0+0+++++0+00+000000++++000+t+$ $+0 \mathrm{u} t+++++++0+-+0+++++0+00+000000++++000+t+$ $t+00+++t++++0+0+0++t++0+00+000000++++000+t+$ $++00+++++++0+0+0+++++0+00+000000++++000+t+$ $++00++++++++0+0+0+++++0+00+0000000++++000+t+$ $++00+t++t+++0+0+0+t+t+0+00+0000000+t+000+t+$ $++00++++++++0+0+0+++++0+00+000000++++000+t+$

+ : Growth 
1solates. Table VII reveals that YE1, YE40, YE56, and YE79 require both vitamin supplement and casamino acids for growth, while CA45b and CA77 require only casamino acids for growth.

Differential Features. Although the 34 arsenite oxtdizing isolates have many similarities, they could be differentiated into two groups each with three or four types. Group I consists of strains YE1, YE8, YE15, YE40, YE47, YE56, YE58, YE79, YE83, YE86, CA4, CA8, CA10, CA11, CA27, CA34, CA57, CA77, CA80, and G6a. Group II consists of strains YE10, YE11, CA44, CA45a, CA45b, G1, G6b, G7, G14, G27, G31, G33, G35.

I. Colonial Form. On the surface of NBYE, Group I strains formed circular, entire, translucent colonies with a smooth convex or smooth umbonate surface. Group II strains resembled Group I strains at first but after 48 hours formed semi-fluid colonies which readily coalesced to form large colonies. CA44 is unique; its colonies are punctiforn.

II. Group I organisms accumulate poly-beta-hydroxybutyrate, do not possess arginine dihydrolase and the "meta" cleavage enzyme for protocatechuate. None of these strains produce pigment in King A, King B or'Stanier Medium. Group II organisms do not accumulate poly-betahydroxybutyrate, do possess arginine dihydrolase and the "ortho" cleavage enzyme for protocatechuate. They produce a weak fluorescent watersoluble pigment on King B medium. Strains CA44, CA45a and G6b produced a water soluble brown plgment on the single carbohydrate media, e.g. maltose, while YEII and CA45b produced a brown pigment on King A and B medium only.

III. Group II organisms with the exception of CA45a do not 
reduce nitrate to nitrite under aerobic conditions, while Group I organisms do.

IV. Table VII shows the results of the tests for ability to grow on different organic compounds. The strains cannot be allocated Into distinct groups using this characteristic. This is partially due to the difficulties inherent in the method itself since false positive results occur when a nonutilizable chemical is contaminated with small amounts of a utilizable chemical. False positive results can be avoided If the substrate concentration is kept as low as possible; however, under these clrcumstances growth is siigit in the positive cases so that each test series must include a control plate without added organic compounds, and a control NBYE plate to conflrm the viability of the inoculum. Late growth of a few colonies in the area of the spot were presumed to arise from mutants in the inoculum and these were scored as negative.

The construction of an ideal phenocype for the two groups of isolates would allow them to be treated as groups possessing certain collective properties. This can be accomplished by scoring the above characteristics of high frequency as positive and the characteristics of low frequency as negative. The characters and their frequencies for the two groups are listed in Table VIII. A key characterizing the pseudomonads has been reproduced from Stanier et al., (1966), Table IX. The Ideal phenotype of Group I can be classified as belonging to the acidovorans group of aerobic pseudomonads and the Ideal phenotype of Group II can be classified as belonging to the fluorescent group. Stanier et al., (1966) constructed a list of traits chosen for 


\section{TABLE VIII}

GENERAL CHARACTERS OF DIAGNOSTIC VALUE FOR THE DIFFERENTIATION

OF TWO GROUPS OF AEROBIC ISEUDOMONADS

\begin{tabular}{|c|c|c|c|c|}
\hline$i$ & $(21 \mathrm{~s}$ & $\begin{array}{l}\text { I } \\
\text { tested) }\end{array}$ & (13 s & ested) \\
\hline CHARACTER & $\begin{array}{l}\text { Positive } \\
\text { Strains }\end{array}$ & $\begin{array}{c}\text { Ideal } \\
\text { Phenotype }\end{array}$ & $\begin{array}{l}\text { Positive } \\
\text { Strains }\end{array}$ & $\begin{array}{c}\text { Ideal } \\
\text { Phenotype }\end{array}$ \\
\hline Total Number of Strains & 21 & & 13 & \\
\hline Number of Flagella $<1$ & 21 & + & 13 & + \\
\hline $\begin{array}{l}\text { p-B-OHbutyrate Accumulation } \\
\text { Pigments }\end{array}$ & 21 & + & 1 & 0 \\
\hline Fluorescent & 0 & - & 13 & + \\
\hline Phenazine & 0 & - & 0 & - \\
\hline Cartenold & 0 & - & 0 & - \\
\hline Growth Factor Requirements & 5 & - & 1 & - \\
\hline Denftrification & 21 & + & 13 & + \\
\hline Extracellular Hydrolases & & & & \\
\hline Gelatin & 0 & - & 1 & - \\
\hline Starch & 0 & - & 0 & - \\
\hline Oxidase Reaction & 21 & + & 13 & + \\
\hline Arginine Dihydrolase & 0 & - & 13 & + \\
\hline Cleavage Mechanism for Diphenols & 21 & Meta & 13 & Ortho \\
\hline Growth at $4^{\circ} \mathrm{C}$ & 0 & - & 0 & - \\
\hline $41^{\circ} \mathrm{C}$ & 0 & - & 0 & - \\
\hline
\end{tabular}


TABLE IX**

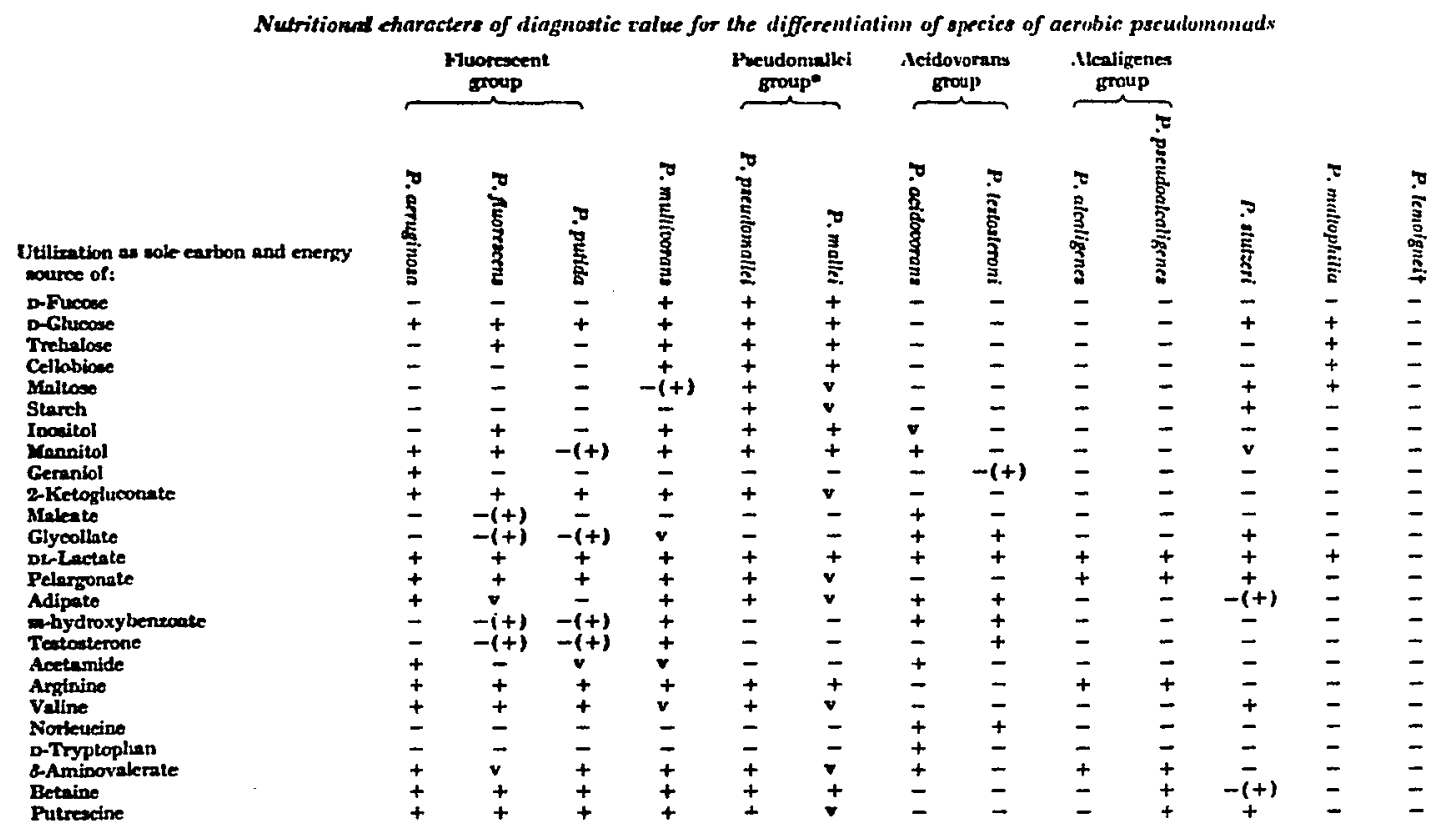

General characters of diagnastic oalue for the differentiation of species of aerobic psendomonads

Frooreseen:

groesp sroup*

Actdovoran Broup

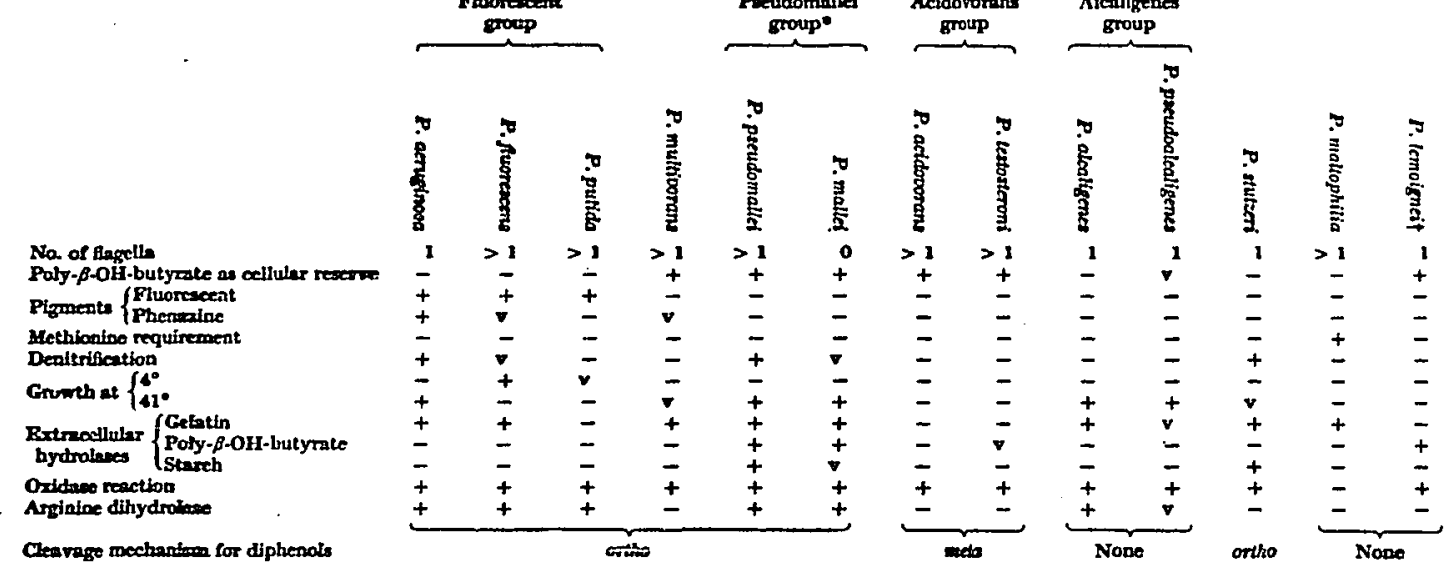

- Inese of Redtean a al (1008). I Date of Delufield at al. (1963).

$+\infty$ positlve.

$-(+)=$ usmlly negative, occasionelly positive.

- a alvaya segalive. $\quad \mathrm{v}$ o variable.

* Stander et al., (1966) 
their value in permitting the differentiation of fluorescent pseudomonads. The traits and their frequencies in the 175 strains he examined are listed in the first two columns of Table $X$. In the third and fourth columes are listed the fluorescent group organisms isolated In the present study. With respect to the 16 characteristics tested which describe the ideal phenotype of the fluorescent group, conformity of the 13 isolates in Group II with the fluorescent group is questionalbe. As shown in Table X, all 13 strains deviated by more than two characteristics which was the maximum deviation Stanier's group allowed. Nevertheless, these 13 arsenite oxidizing isolates must be considered aerobic pseudomonads belonging to the fluorescent group because they do possess fluorescent pigment and within that group most closely resemble Pseudomonas fluorescens, Table XI.

A simliar znalysis was made of the 21 arsenite oxidizing isolates of Group I classified as belonging to the acidovorans group; conformlty of the Isolates with the acidovorans group is good, Table XII. As shown in Table IX, the acidovorans group contains two species, $\underline{P}$. acidovorans and. $\underline{R}$. testosteroni. Pseudomonas testosteront was named on the basis of a single striking character, its ability to grow on testosterone and related steroids; later, however, Stanier et al., (1966) showed this nutritional character to be taxonomically significant. None of the $2 I$ isolates of the present study will grow on testosterone. They differ from Stanier's classification only by being able to denitrify and to oxfidize arsenite, a characteristic which Stanier had not tested. Therefore, Group I is assigned to the species Pseudomonas actdovorans and called Pseudomonas acidovorans-arsenoxydans. 
TABLE $X$

THE GROUP CHARACTERS OF GREATEST DIFFERENTIAL

VALUE IN THE RECOGNITION OF THE

FLUORESCENT PSUEDOMONADS

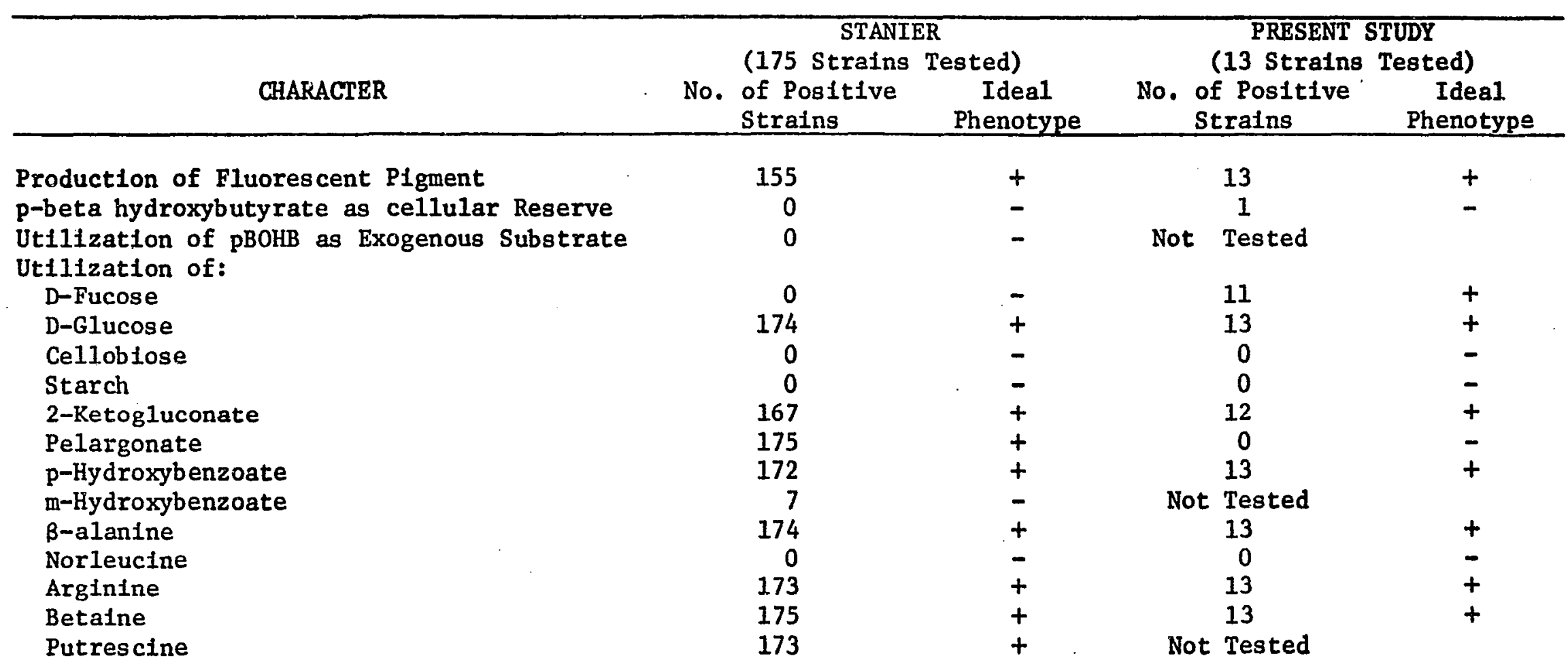




\section{TABLE XI}

CHARACTERS FOR THE DIFFERENTIATION OF

P. FLUORESCENS AND $\underline{P}$. PUTIDA

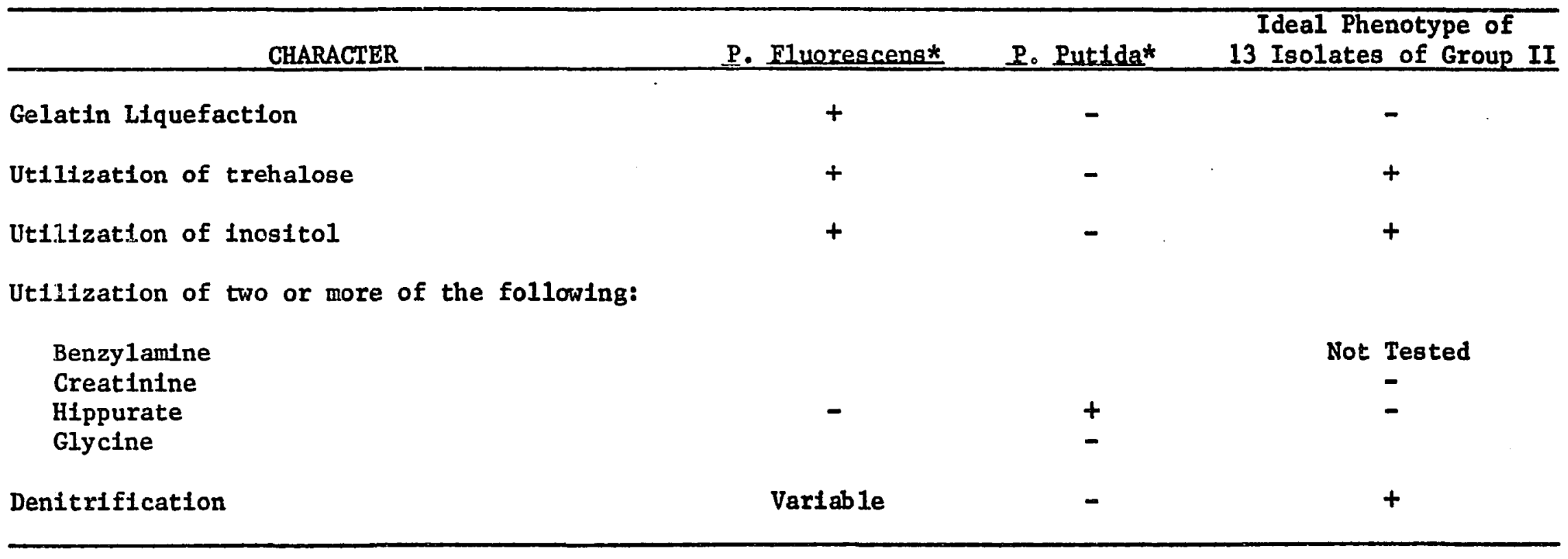

* Data for $\underline{\underline{P}}$ fluorescens and $\underline{\mathrm{P}}$. put1da taken from Stanter et $\underline{\text { al }}$. (1966). 


\section{TABLE XII}

THE GROUP CHARACTERS OF GREATEST DIFFERENTIAL VALUE IN THE RECOGNITION OF THE ACIDOVORANS GROUP

\begin{tabular}{|c|c|c|c|c|}
\hline \multirow[b]{2}{*}{ CHARACTERS } & \multicolumn{2}{|c|}{$\begin{array}{c}\text { STANIER } \\
\text { (26 Strains Tested) }\end{array}$} & \multicolumn{2}{|c|}{$\begin{array}{c}\text { PRESENT STUDY } \\
\text { (21 Strains Tested) }\end{array}$} \\
\hline & $\begin{array}{l}\text { No. of Positive } \\
\text { Strains }\end{array}$ & $\begin{array}{c}\text { Ideal } \\
\text { Phenotype }\end{array}$ & $\begin{array}{l}\text { No. of Positive } \\
\text { Strains }\end{array}$ & $\begin{array}{c}\text { Ideal } \\
\text { Phenctype }\end{array}$ \\
\hline $\begin{array}{l}\text { B-beta hydroxybutyrate as cellular reserve } \\
\text { Utilization of: }\end{array}$ & 26 & + & 21 & + \\
\hline L-arabinose & 0 & - & 0 & - \\
\hline D-glucose & 0 & - & 3 & -- \\
\hline D-galactose & 0 & - & 0 & - \\
\hline 2-Ketogluconate & 0 & - & 0 & -- \\
\hline Saccharate & 25 & + & 21 & + \\
\hline Pelargonate & 0 & - & 0 & - \\
\hline Adipate, pimelate & 26 & + & 21 & + \\
\hline Glycollate & 24 & + & 21 & + \\
\hline Levulinate & 26 & + & Not Tested & - \\
\hline Itaconate & 26 & + & 0 & - \\
\hline m-Hydroxybenzoate & 25 & + & 21 & + \\
\hline Norleucine & 25 & + & 21 & + \\
\hline Putrescine & 0 & - & Not Tested & - \\
\hline
\end{tabular}


Identification

Common features. Al1 34 arsenite oxidizing isolates were gram negative, actively motile, less than one micron in diameter, nonspore forming straight rods with two polar flagella, Figure 9. All were capable of denitrification, i.e., all possessed the ability to anaerobically use nitrate instead of molecular oxygen as a terminal electron acceptor, reducing it to nitrogen gas. All were incapable of anaerobic metabolism of the compounds they used aerobically as a source of carbon and energy for growth. In addition, none of the isolates grew at $4^{\circ} \mathrm{C}$ or $41^{\circ} \mathrm{C}$; only CA45b hydrolyzed gelatin; no isolate hydrolyzed starch, glycogen, or changed litmus milk; all were oxidase and catalase positive; all used gluconate, lactate, pyruvate, Krebs cycle intermediates, beta-alanine, aspartate, glutamate, tyrosine, betaine, and parahydroxybenzoate as a sole source of carbon and energy for growth; all used ammonium salts as a sole nitrogen source (YE56 could use nitrate as a sole nitrogen source); none of the strains were hemolytic when grown on the surface of sheep blood agar, and all grew iuxuriantly on the usual meat infusion or yeast extract type of culture media and are, therefore, typical heterotrophic microbes.

A definitive study on pseudomonads (Stamier et al., 1966) resulated in the description of aerobic pseudomonads as ...unfcellular rods with the long axis straight or
curved but not helical. Motile by means of one or more
polar flagella. Gram negative. Do not form spores,
stalks, or sheaths. The energy yielding metabolism is
respiratory, never fermentative or photosynthetic. All
use molecular oxygen as a terminal oxidant, and some
can use denitrification as an alternative, anaerobic
reopiratory mechenism. All are chemoorganotrophs; some
are facuitacive cinemolithotrops that use molecular
hydrogen as an energy source. 


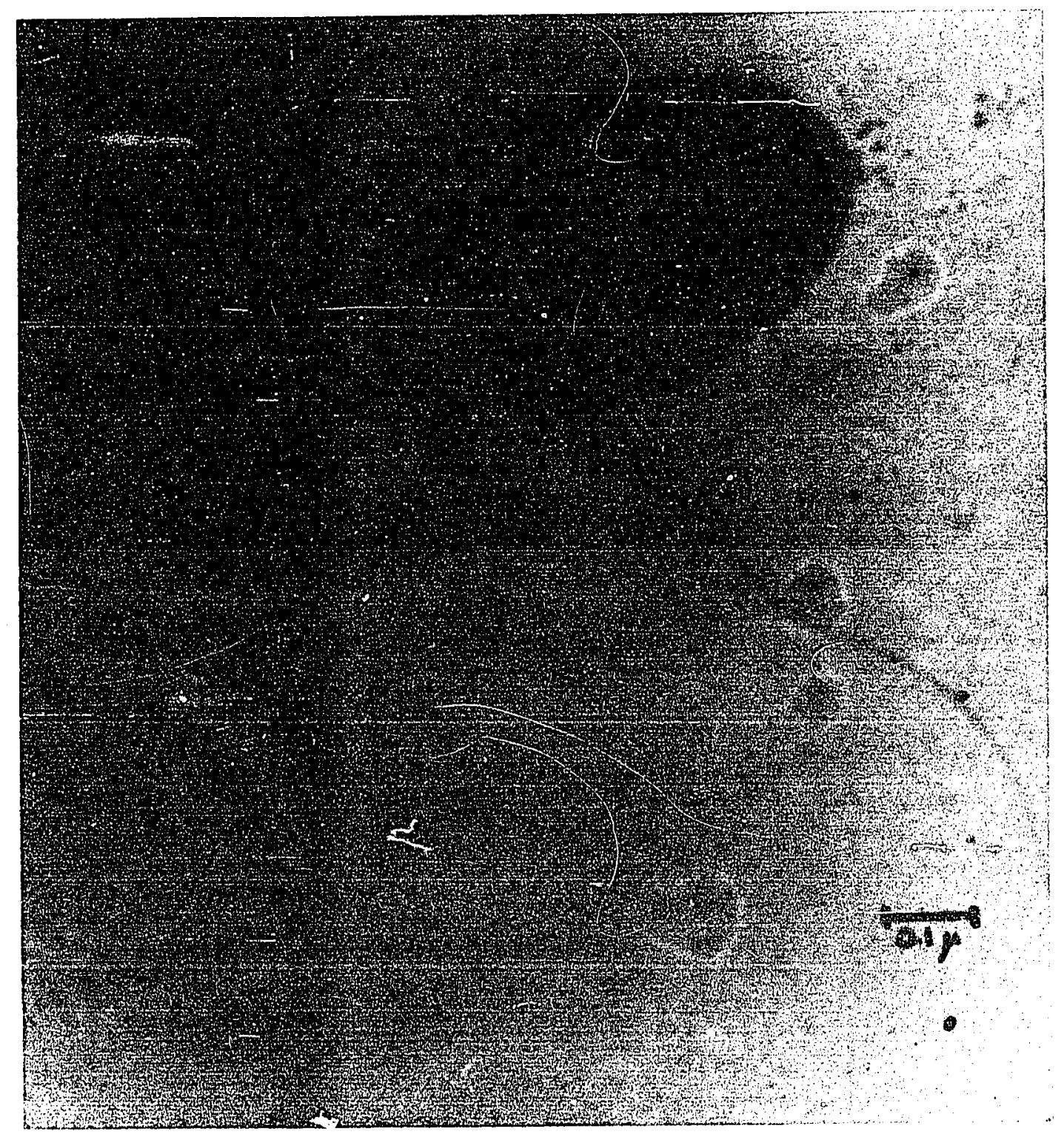

Figure 9. Pseudomonas sp. (YE56) showing polar flagella typical of all 34 isolates, magnified approximately 20,000 times. 
Thus, according to these characteristics, all 34 strains would be classified with the genus Pseudomonas.

One organism, Pseudomonas acidovorans-arsenoxydans YE56, was selected for further study because it provided a good yield of cells which rapidly oxidized arsenite. As shown in Table XIII, YE56 grows on BSM supplemented with vitamins and 0.5 percent Difco yeast extract or 0.1 gram per liter vitamin-free acid-hydrolyzed casein. Since Difco yeast extract contains no alanine, serine, proline or hydroxyproline (Difco Laboratories, personal communication) and since vitamin-free acid-hydrolyzed casein contains no asparagine, glutamine, or tryptophan (Nutritional Biochemical Company, personal compunication), these amino acids were omitted from the tests. Fifty micrograms per ml final concentration of each of the other amino acids were added to CDM without the casamino acid supplement in various combinations: Group I, valine and leucine; Group II, aspartic acid, methionine, threonine, isoleucine, and Iysine; Group III, glutamic acid and arginine; Group IV, glycine, cystine, tyrosine, phenylalanine and histidine. As shown in Tables XIV and XV, BSM used for the growth of YE56 could be supplemented with aspartic and/or glutamic acids and $12 \mathrm{ml}$ per liter vitamin supplement. Table XVI shows that the optimum doubling time was obtained with equal amount of aspartic and glutamic acids. This doubling time (100 minutes) was comparable to that obtained when 100 micrograms per $m 1$ casamino acids replaced the essential amino acids.

It appeared that arsenite oxidation was associated with biological activity because a solution of $0.02 \mathrm{M}$ sodium arsenite, $\mathrm{pH} 9.0$, was stable on the laboratory shelf for over a year since no arsenate 
TABLE XIII

SPECIFIC REQUIREMENTS OF THE NUTRITIONALLY

EXACTING STRAINS

\begin{tabular}{|c|c|c|c|c|c|c|}
\hline \multirow[b]{2}{*}{ SUPPLEMENT } & \multicolumn{6}{|c|}{ STRAIN } \\
\hline & YE1 & YE40 & YE56 & YE79 & $\mathrm{CA} 45 \mathrm{~b}$ & CA77 \\
\hline None & 0 & $\mathbf{0}$ & 0 & 0 & 0 & 0 \\
\hline Vitamins, minerals and Casamino Acids & + & + & + & + & + & 4 \\
\hline Minerals Only & 0 & 0 & 0 & 0 & 0 & 0 \\
\hline Vitamins and minerals & 0 & 0 & 0 & 0 & 0 & 0 \\
\hline Vitamins and casamino actds & + & + & + & + & + & + \\
\hline Minerals and casamino acids & 0 & 0 & 0 & 0 & + & + \\
\hline
\end{tabular}

$0=$ No growth; $t=$ Growth as measured by an Increase in optical density after 18 days incubatioja in standard BSM with supplements as shown. 
TABLE XIV

DETERMINATION OF SPECIFIC AMINO ACID

REQUIREMENTS OF STRAIN YE56

\begin{tabular}{lc}
\hline SUPPLEMENT & GROWTH \\
\hline EXPERIMENT I & + \\
Casamino acids & + \\
Group I, II, III, IV & + \\
Group I, III, IV & + \\
Group II, III, IV & + \\
Group I, II, IV & + \\
Group I, II & + \\
Group I, III & + \\
Group I, IV & + \\
Group II, III & + \\
Group II, IV & + \\
Group III, IV & +
\end{tabular}

$0=$ No growth

$+=$ Growth as maasured by increase in optical density at 660 nanameter after 18 hours incubation. 
TABLE XV

DETERMINATION OF SPECIFIC AMINO ACID

REQUIREMENTS OF STRAIN YE56

SUPPLEMENT

Rlett Readings

(\#66 filter)

GROWTH

Experiment 2

200 micrograms/ml casamino acids

$200 \mathrm{micrograms} / \mathrm{ml}$ aspartic acid

50 micrograms/ml each isoleucine, Iysine, methionine, threonine

5́o micrograms/ml each arginine, proline, glutamic acid, aspartic acid

Experiment 3

100 micrograms $/ \mathrm{ml}$ casamino acids 45

$100 \mathrm{micrograms} / \mathrm{ml}$ aspartic acid 30

$50 \mathrm{micrograms} / \mathrm{ml}$ each aspartic acid, glutamic acid 50

50 micrograms/ml each aspartic acid, proline 50

$50 \mathrm{micrograms} / \mathrm{ml}$ each aspartic acid, arginine 38

Amino acids were adjusted to $\mathrm{pH} 6.8$ with hydrochloric acid or sodium hydroxide before autoclaving. Growth was measured after 18 hours incubation using a Klett-Summerson colorimeter with a 非6 filter. 
TABLE XVI

RELATIONSHIP BETWEEN GROWTH AND CONCENTRATIONS

OF TWO REQUIRED AMINO ACIDS

\begin{tabular}{cccc}
\hline $\begin{array}{c}\text { ASPARTIC ACID } \\
\text { MICROGRAMS/ML }\end{array}$ & $\begin{array}{c}\text { GLUTAMIC ACID } \\
\text { MICROGRAMS/ML }\end{array}$ & $\begin{array}{c}\text { DOUBLING TIME } \\
\text { MINUTES }\end{array}$ & $\begin{array}{c}\text { TOTAL CELL YIELD } \\
\text { MICROGRAMS } \\
\text { PROTEIN/ML }\end{array}$ \\
\hline 100 & 0 & 135 & 37.7 \\
70 & 30 & 130 & 42.3 \\
50 & 50 & 100 & 47.0 \\
30 & 70 & 144 & 47.0 \\
10 & 90 & 144 & 47.0 \\
0 & 100 & 155 & 47.3
\end{tabular}


could be detected by TLC of the solution. That the oxidation of arsenite to arsenate required a "Ilving cell" and was not due to some nonspecific interaction of cell protein, medium and/or cofactors was demonstrated by the following: Pseudomonas acidovorans-arsenoxydans YE56 was grown overnight in CDM containing $0.02 \mathrm{M}$ arsenite, and the culture was divided into two equal parts. One part was bolled for ten minutes; then both parts were diluted into fresh medium containing $0.02 \mathrm{M}$ arsenite. While neither growth nor arsenite oxidation occurred In the boiled culture, the unboiled portion of the ceils grew and oxidation of arsenite to arsenate was complete in less than 36 hours. Differences in the rate of arsenite oxidation among the strains, as shown in Table XVII, reflect factors other than the capability of the organism to carry out this oxidation. Observations made in this laboratory suggest that one of the most important factors affecting arsenite oxidation is the growth rate of the organism. [Marked differences in growth rate have been observed, e.g. CA44 has an extremely slow generation time (days) while YE56 has a generation time of approximately 70 minutes.] The medium also appeared to influence the rate of arsenite oxidation, Table XVII. Therefore the factors which affect generation time and/or arsenite oxidation were studied in detail using Pseudomonas acidovorans-arsenoxydans YE56.

\section{Temperature}

Growth. In most studies the optimum temperature for growth is defined as that which permits the most rapid growth rate; although it has been defined in the past on the bas ls of the amount of cells produced (Thimann, 1963), In which case the optimum temperature for 
TABLE XVII

ARSENITE REMAINING AFTER THREE DAYS OF GROWTH

FOR EACH ISOLATE IN TWO DIFFERENT MEDIA

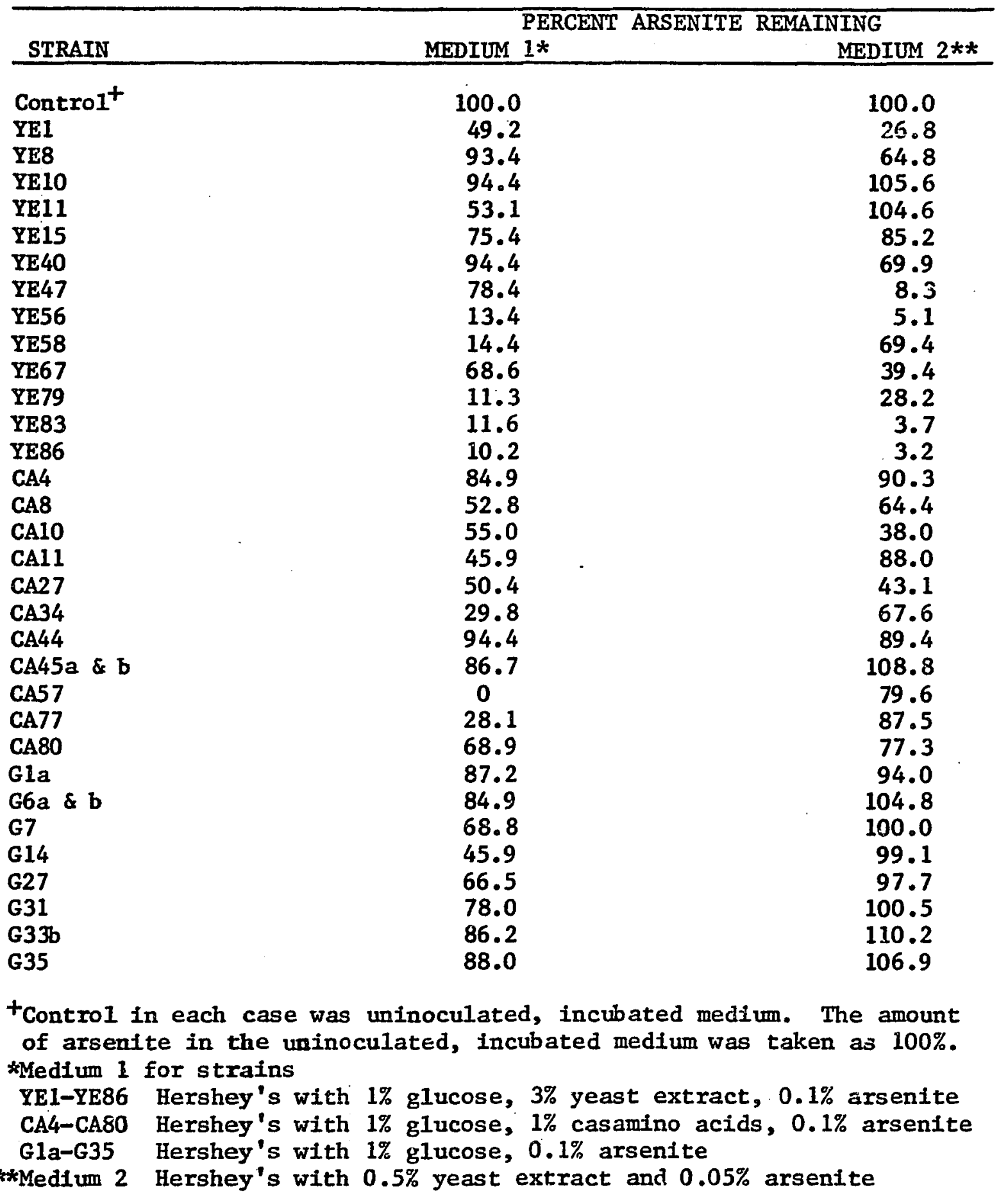


the aerobic organism is usually found to be several degrees below the optinum temperature based on growth rate. Sinclair and Stokes (1963) found that the higher cell yields obtained at lower temperatures were due to the increased solubility of oxygen at lower temperatures, and therefore, availability of oxygen to the organisms. They found that equal cell yields were produced at high and low temperatures when batch cultures were vigorously aerated so that oxygen was not limiting. Therefore, in this study the doubling time was chosen as the most reliable parameter of the effect of temperature on growth.

Wo growth occurred at $4^{\circ} \mathrm{C}$, but the cells had remained viable as determined by their ability to produce visible turbidity in the growth nedium when the tubes were returned to room temperature. The maximum temperature for growth is between $39^{\circ} \mathrm{C}$ and $41^{\circ} \mathrm{C}$. The optimum growth temperature was near $32^{\circ} \mathrm{C}$ as shown in Table XVIII.

The maximum, minimum and optimum temperature values are subject to change by $\mathrm{pH}$ (Gale and Epps, 1942), nutrition (Campbel1, 1954), and especially pressure (Zobell and Johnson, 1949).

Ideally an in vitro study of the effect of temperature on growth rate would include a 4 dimensional matrix varying temperature, pH, nutrition, and pressure. The relationship between temperature and pressure, while not significant under laboratory conditions (constant pressure) must be of considerable importance in the grit chamber of a sewage treatment plant where these strains were found and where the effects of vaxying pressure may be profoundly modified according to the equation $P V=$ NRT.

Activity. Resting cells from stationary growth phase of YE56 were 


\section{TABLE XVIII}

THE EFFECT OF TEMPERATURE ON THE GROWTH OF

PSEUDORONAS ACT IOVORANS-ARSENOXYDANS YE56

TEMPERATURE ${ }^{\circ} \mathrm{C}$

DOUBLING TIME IN MINUTES

4.0

22.0

27.0

32.0

33.5

37.0

41.0

\section{Infinite}

222

136

101

103

118

No Growth 
centrifuged and resuspended in $0.1 \mathrm{M}$ phosphate buffer, $\mathrm{pH} 6.8$, to contain 578 micrograms proteln per $3 \mathrm{ml}$, and the rate of oxygen uptake was measured at various temperatures.

Two controls were included (boiled bacteria in $0.1 \mathrm{M}$ phosphate buffer, $\mathrm{pH} 6.8$, containting $0.01 \mathrm{M}$ sodium arsenite or boiled bacteria in $0.1 \mathrm{M}$ potassium phosphate buffer, $\mathrm{pH} 6.8$ containing $0.01 \mathrm{M}$ arsenate) to Insure that the change in reaction rate with temperature was not the result of a chemical conversion of arsenite to arsenate.

The oxygen probe is sensitive to changes in the pressure of oxygen and as the temperature increases, the diffusion of oxygen increases so that more oxygen comes into contact with the probe. To compensate, a thermoresistor has been built into the apparatus with an effective range from $25^{\circ} \mathrm{C}$ to $40^{\circ} \mathrm{C}$. Thus the data in Table XIX is not reliable above $40^{\circ} \mathrm{C}$. However, as shown in Figure 10, the energy of activation for bacterial arsenite oxidation could be found from an Arrhenius plot to be 16.2 kilocalories per mole. The $Q_{10}$ for arsenite oxidation from $30^{\circ} \mathrm{C}$ to $40^{\circ} \mathrm{C}$ was found to be 2.46 , and the values obtained within the temperature ranges of this experiment were between 2.40 and 2.53 . Turner (1949) found the activation energy for the oxidation of arsenite by his organism to be 7,750 calories per mole which he felt was in the range for a diffusion process instead of active transport.

\section{Aeration}

Growth. Figure 11 shows that oxygen supply can limit the generation time; therefore, it appeared that for the maximal growth rate with this organism the main problem was to provide sufficient oxygen. Pseudomonas acidovorans-arsenoxydans YE56 is a strict aerobe thus when 
TABLE XIX

THE EFFECT OF TEMPERATURE ON THE RATE OF ARSENITE OXIDATION BY WASHED SUSPENSIONS. OF. PSEUDOMONAS ACIDOVORANS-ARSENOXYDANS YE $\overline{56}$

\begin{tabular}{cccc}
\hline $\begin{array}{c}\text { TEMPERATRE } \\
{ }^{\circ} \mathrm{C}\end{array}$ & $\begin{array}{c}1 / \mathrm{T} \times 10^{3} \\
\left(\mathrm{~T} \text { in } \mathrm{K}^{\circ}\right)\end{array}$ & $\begin{array}{c}\text { VELOCITY } \\
\text { (Percent } 0_{2} \\
\text { Uptake/min) }\end{array}$ & $\begin{array}{c}\text { SPECIFIC } \\
\text { ACTIVITY* }\end{array}$ \\
\hline 28.0 & 3.322 & 2.00 & 3.15 \\
30.5 & 3.295 & 2.25 & 3.41 \\
32.0 & 3.278 & 2.94 & 4.36 \\
35.0 & 3.247 & 4.06 & 5.79 \\
37.3 & 3.232 & 5.00 & 6.94 \\
40.0 & 3.195 & 6.12 & 8.25 \\
42.0 & 3.174 & 7.67 & \\
45.0 & 3.145 & 8.50 & \\
47.0 & 3.125 & 8.25 & \\
47.5 & 3.120 & 8.00 & \\
\hline
\end{tabular}

* Specific Activity micromoles arsenite oxidized per hour/milligram protein. 


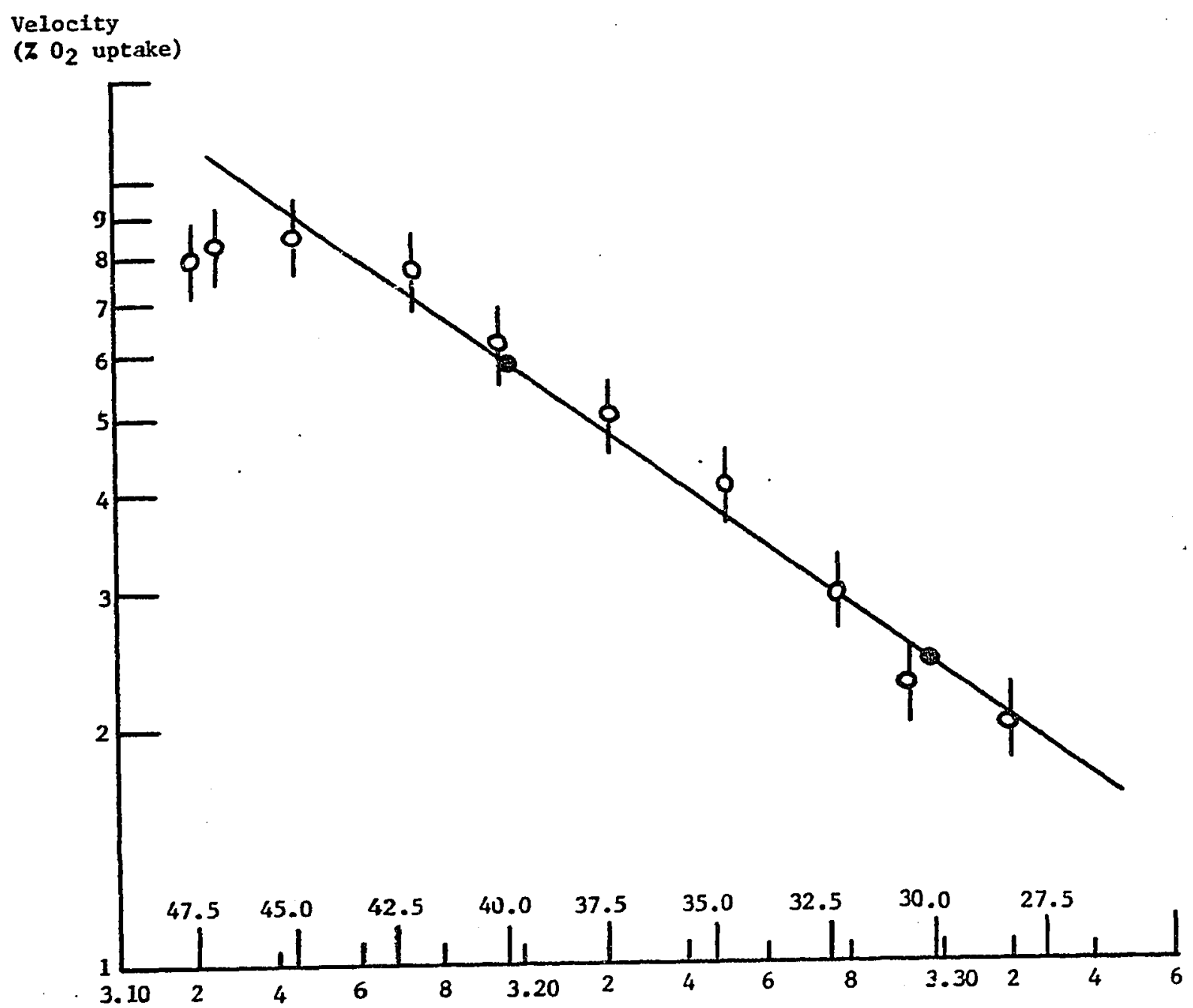

Figure 10. Arrianius Plot of the Rate of Arsenite Oxidation. 

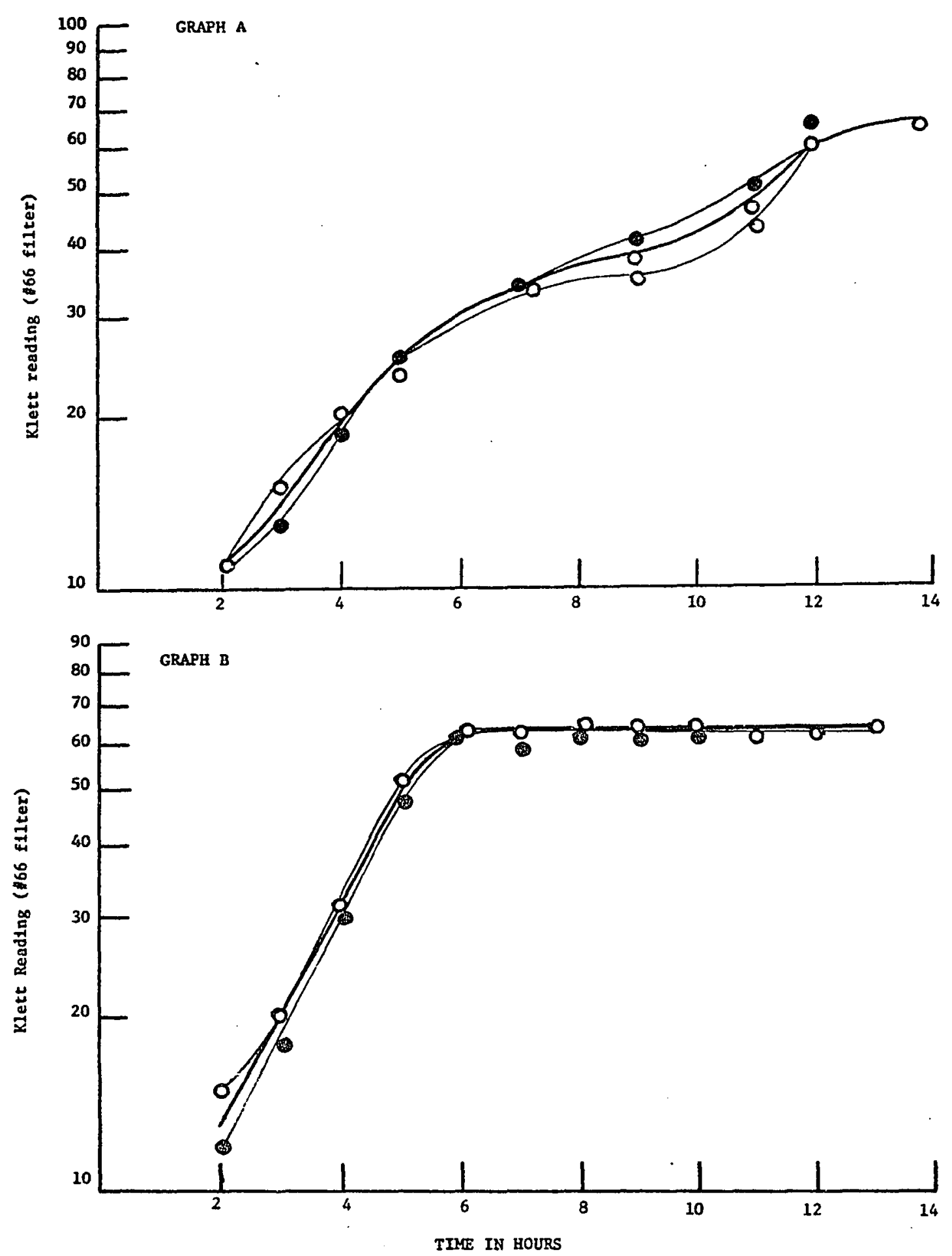

Figure 11. Effect of aeration on the growth of PseuJomonas actdovorans-arsenoxydans YE56. Cultures were grown at $31^{\circ} \mathrm{C}$ in 2 liter flasks filled to 10 percent of their capacity in CDM with $0.5 \mathrm{~g} / 1$ sodiun citrate, $\mathrm{pH} 6.9$. The culture in Graph " $\mathrm{B}$ " was Incubated with vigorous aeration. (360 rpm) on a New Brunswick gyrorotory shaker; the culture in Graph " $A$ " wat Incubated in a statlonary constant temperature incubator. [0, no arsenite; $0-0-0,0.01 \mathrm{M}$ arsenite added to the medium.] 
the substrates tested in Table VII were incubated inder anaerobic conditions in a BBL "gas pak" jar, no growth occurred. Gaby et al., (1962) found that Pseudomonas cells equivalent to one gram dry welght can use all the oxygen from one liter of air saturated medium containing serine as the carbon source in approximately $10 \mathrm{~min}$. Because the solubility of oxygen in a basal salts medium is low $[5.88 \mathrm{mg}$ per liter for air-saturated medium containing 5 percent glucose at $30^{\circ} \mathrm{C}$ (Phillips and Johnson, 1961)] and the oxygen requirements for YE56 is high, cultures were grown in a gyrotory incubator shaker to Increase oxygen solution rates and to maintain an excess amount of dissolved oxygen in order to obtain high cell yields. In addition growth in this manner maximized cell contact with other nutrients and prevented cell clumping. This was especially important since pseudomonads tend to remain aggregated (Hou et al., 1966) which presents difficulties in turbidity measurement.

To study the effect of surface/volume ratio of the medium and the shaking rate of the gyrotory shaker on the generation time and cell yield, two sets of experiments were performed. One set of experiments used flasks of 125,250 , and $500 \mathrm{ml}$ capacity and each filled to 15 percent of its capacity with the culture medium. These flasks were incubated in a vertical position and shaken at approximately $360 \mathrm{rpm}$. The other set of experiments used flasks of $500 \mathrm{ml}$ capacity and each filled with $25,50,75,100,125$, or $150 \mathrm{ml}$ respectively. The results are shown in Table $X X$ and $X X I$; the doubling time is accurate to 10 percent and the yield is accurate to 15 percent. Table XXI suggests that although differences in doubling times are not large, the doubling time 
TABLE XX

RELATIONSHIP BETWEEN GROWTH AND FLASK SIZE

AT SHAKE RATE OF 360 RPM

\begin{tabular}{cccc}
\hline $\begin{array}{c}\text { FLASK SIZE } \\
(\mathrm{m} 1)\end{array}$ & $\begin{array}{c}\text { SURFACE/*VOLUME } \\
\text { RATIO }\end{array}$ & $\begin{array}{c}\text { AVERAGE DOUBLING } \\
\text { TIME (minutes) }\end{array}$ & $\begin{array}{c}\text { AVERAGE TOTAL } \\
\text { CELL YIELD** }\end{array}$ \\
\hline 125 & 2.4 & 84 & 22.5 \\
250 & 2.3 & 83 & 22.0 \\
500 & 2.0 & 82 & 21.0 \\
\hline
\end{tabular}

* Ratio of exposed surface to total volume of medium in standing flask

tri: Micrograms protein per ml of culture 
TABLE XXI

THE EFFECT OF AERATION ON THE DOUBLING TIME

AND CELL YIELD OF STRAIN YE56

\begin{tabular}{|c|c|c|c|c|c|c|}
\hline \multirow{2}{*}{$\begin{array}{l}\text { VOLUME: } \\
\text { (m1/500 mil } \\
\text { flask) }\end{array}$} & \multicolumn{3}{|c|}{ DOUBLING TIME (MIN) } & \multicolumn{3}{|c|}{ CELL YIELD* } \\
\hline & 3218 RPM & 360 RPM & $400 \mathrm{RPM}$ & $320 \mathrm{RPM}$ & $360 \mathrm{RPM}$ & 400 RPM \\
\hline 25 & 87 & 84 & 79 & 27 & 28.5 & 28 \\
\hline 50 & 84 & 78 & 75 & 27 & 25.5 & 27.5 \\
\hline 75 & 87 & 90 & 88 & 27 & 25 & 27.5 \\
\hline 100 & 90 & 90 & 88 & 27 & 24.5 & 25.5 \\
\hline 125 & 90 & 90 & 93 & 27 & 24 & 25.5 \\
\hline 150 & 137 & 108 & 94 & 27 & 24 & 25.5 \\
\hline
\end{tabular}

* Micrograms protein per ml of culture. 
decreases in relation to the increase in shaking speed. Due to limitations of the machine, there was no indication that the maximum growth rate had been attained. Although it is within the range of variation of this experiment, the decrease in doubling time when the flasks were filled to only 5 percent of their volumetric capacity was reproducible and verffied by other experimental observations. As can be seen the final cell yield was independent of the shake rate. Aithough der anaerobic conditions the organism can use nitrate as an electron acceptor for the oxidation of various carbon sources, nitrate could not serve as an electron acceptor for the oxidation of arsenite under these conditions. However, while the presence of nitrate did not peramt arsenite oxidation under anaerobic conditions, under aerobic condittans the presence of nitrate in the arsenite containing growth medium diud not interfere with arsenite oxidation by the culture. In another experiment a culture of YE56 was Inoculated into nitrate broth and nitrate broth containing $0.02 \mathrm{M}$ sodium arsenite and both tubes incubated anaeraßically. After 24 hours growth (which had allowed for induction of anferobic respiration in the nitrate broth) the nitrate broth culture diluted into the inoculated nitrate broth containing sodium arsenite.. The culture was then divided and placed into two flasks: the control flask was incubated aerobically, the second flask was Incubated anaerobically. Whereas the control culture continued to grow as expected, the anaerobic culture containing arsenite did not grow, In spite of the presence of nitrate, nor did it oxidize arsenite as estimed by ilodomerric titration. Thus it appears that the presence of arsenite in the nitrate broth Inhibits anaerobic respiration even 
after cells had been Induced to use nitrate as an altexnate electron acceptor, probably because arsenite inhibits a member of the electron transport system.

Further evidence that there is a labile portion of the electron transport system comes from the following experiments. Arsenite oxidizing induced cells were sonicated. No oxygen uptake occurred as measured by the oxygen probe but the same preparation was able to couple oxidation of arsenite to arsenate with the reduction of 2,6 dichlorolndophenol using the anaerobic Thunberg technique. Since there Is Iittle change in arsenite oxldizing abilfty of sonicated preparations (as measured by the Thumberg technique) which have been held at room temperature with exposure to air for several hours the system is not readily damaged by oxygen. Although the following data must be considered as semi-quantitative only, they provide evidence that the inability of sonlcated extracts from arsenite oxidizing induced cells to oxldize arsenite with oxygen as the electron acceptor is due to disruption of the electron transport system:

1. Suspensions of whole cells were unable to oxidize arsenite in the presence of air after treatment with acetone which is known to extract 1ipid soluble components of the electron transport system, 1.e. coenzyme Q (Lester, 1967).

2. Cells were obtained from cultures in the stationary growth' phase with CDM containing 0.5 gram per liter citrate and $0.01 \mathrm{M}$ sodium arsenite at $32^{\circ} \mathrm{C}$ in the gyrorotory shaking incubator. The cells were harvested by centrifugation, washed, and finally resuspended in twice thelr volume of $0.1 \mathrm{M}$ phosphate buffer, $\mathrm{pH} 6.6$. This suspension 
was sonicated as described in Materlals and Methods. The sonicate was centrifuged at $1475 \times g$ for 30 minutes to remove any whole cells. The supernatant was then centrifuged at $20,000 \times \mathrm{g}$ for 60 minutes at $0^{\circ} \mathrm{C}$. The supernatant was decanted from the pink pellet and each was tested for arsenite oxidizing ability. No activity was observed by the oxygen probe method but approximately 80 percent of the original arsenite oxidizing activity was found in the supernatant when 2,6-dichloropheno1indophenol was used with the Thunberg technique. No arsenite oxidizing activity could be found in the pellet by either the oxygen probe or 2,6-dichlorophenol-indophenol assays.

pㅛㅡ

Growth. As indicated in Table XXII, there are only minor changes In growth as measured by either doubling time or cell yield as long as the final $\mathrm{pH}$ falls between the limits of $\mathrm{pH} 6.0$ to 8.0 . Outside these limits the doubling time was so long that growth is insignificant; below $\mathrm{pH} 5.0$ and above $\mathrm{pH}$ 10.0, no growth was observed.

The optimum growth $\mathrm{pH}$ determined with intact cells and measured In the external environment may differ from the true figure for the cell-free system by an amount determined by the capacity of the cell to control the $\mathrm{pH}$ of its internal environment which cannot be subject to such wide variations in $\mathrm{pH}$. (In the course of these experiments, it was observed that the endogenous rate of oxygen uptake increased as the suspending buffer was made more alkaline from $\mathrm{pH} 7.0$ through 8.0 or as the buffer was made more acid below $\mathrm{pH} 6.0$.)

Activity. The $\mathrm{pH}$ optimum for arsentte oxidation of induced YE56 


\section{TABLE XXII}

THE EFFECT OF THE PH OF THE MEDIUM ON DOUBLING

TIME AND CELL YIELD OF STRAIN YE56

\begin{tabular}{cccc}
\hline $\begin{array}{c}\text { INITIAL } \\
\text { pH }\end{array}$ & $\begin{array}{c}\text { FINAL } \\
\text { pH }\end{array}$ & $\begin{array}{c}\text { DOUBLING TIME } \\
\text { IN MINUTES }\end{array}$ & CELL YIELD* \\
\hline 5.50 & 6.50 & 108 & 30.5 \\
6.00 & 6.69 & 105 & 30.5 \\
6.40 & 6.93 & 102 & 31.0 \\
6.60 & 6.75 & Broken flask & - \\
6.80 & 7.23 & 102 & 31.5 \\
7.00 & 7.43 & 105 & 33.0 \\
7.20 & 7.52 & 114 & 31.5 \\
7.50 & 7.60 & 114 & 31.5 \\
8.00 & 7.84 & 114 & 31.5 \\
\hline
\end{tabular}

* Milcrograms protein per ml of culture 
cells harvested in early stationary phase, washed, and resuspended in $0.1 \mathrm{M}$ phosphate buffers at various $\mathrm{pH}$ 's to a given turbidity was determined from the Initial rate of oxidation by the oxygen probe method over the $\mathrm{pH}$ range 5.7 to 8.1 at $37^{\circ} \mathrm{C}$. As shown in Figure 12, there was a sharp optimum at $\mathrm{pH}$ 6.6. On the same graph is plotted the percent dissociation of arsenious acid $\left(\mathrm{pK}_{2}=6.77\right)$ as calculated from the dissoclation constant given in the Handbook of Chemistry and.Physics (1959). FIgure 13 shows a $\mathrm{pH}$ optimum at 6.6 - 6.8 for arsenite oxidacion when Initial rates were measured in some other buffers. The pH was measured at the beginning and end of all experiments and found to remain constant throughout the experiments except at extreme buffer 11mits; therefore, no correction of the $\mathrm{pH}$ activity curves were made. SInce 2,6 dichlorophenolindophenol continually changes color with changlng $\mathrm{pH}$, we were unable to determine a $\mathrm{pH}$ activity curve for the enzyme system using sonicated cells.

As shown in Figure 14. and 15, growth in the presence of the sulfonic acid buffers (Aces, [N-(2-acetamido)-2-aminoethane sulfonic acid] and Mes, [2(N-morpholino)ethane sulfonic acid]) and Tris, (hydroxymethylamino-methane) or ultra-pure Tris-HCl with or without $0.01 \mathrm{M}$ sodium arsenite made no difference on either the exponential growth rate or inducibility of arsenite oxidation. In contrast, Pipes, (piperazine-N, $N^{\prime} b i s[2-e t h a n e ~ s u l f o n i c$ acid]) inhibited the growth rate with and without arsenite addition. As shown in Table XXIII borate or phthalate buffered media allowed no growth to occur. Cells grown in CDM containing citrate and sodium arsenite as shown in Figures 14 and 15 were Induced to oxidize arsenite to arsenate when cells had reached 


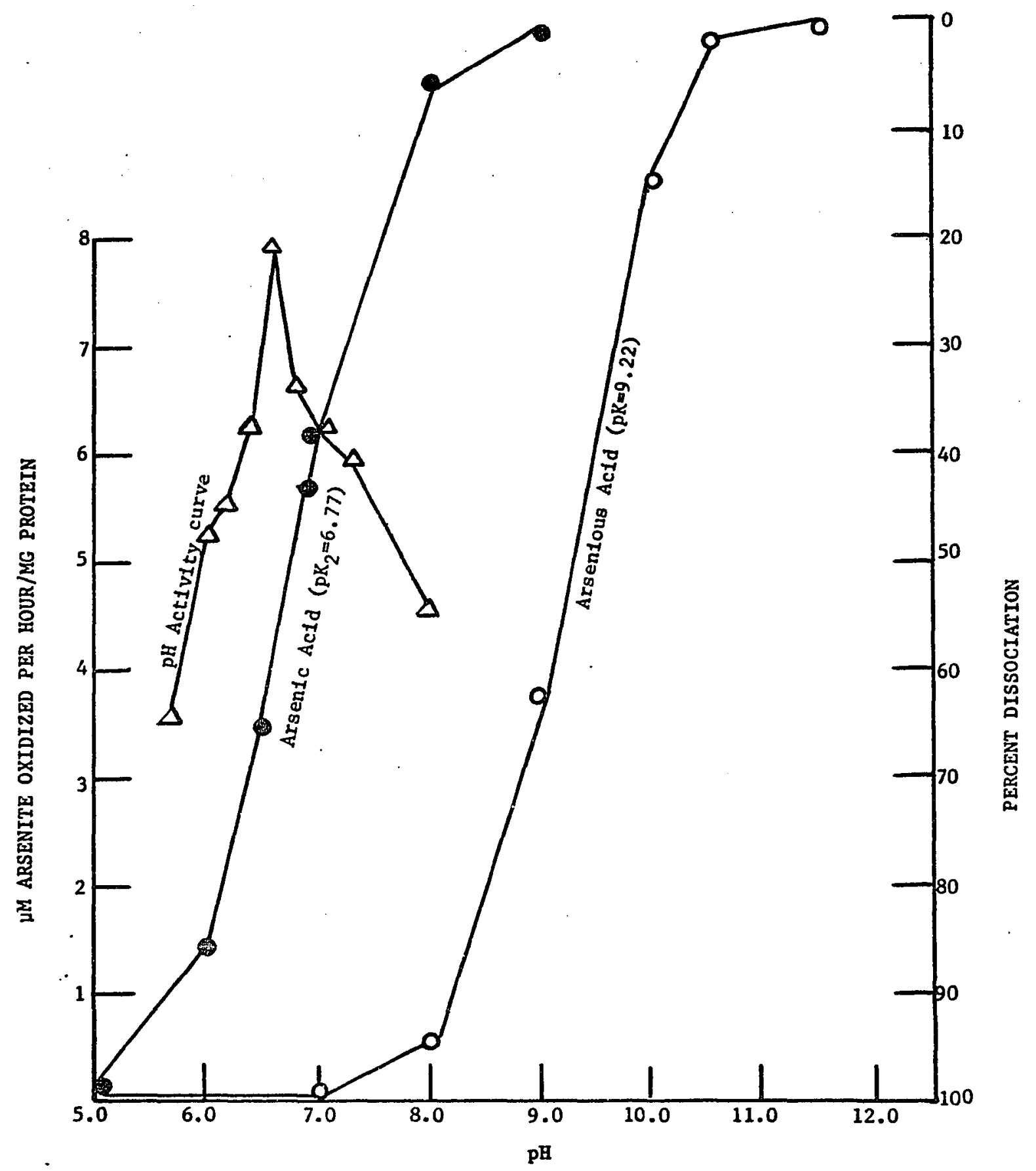

Figure 12. The pH optimum of washed cells of Pseudomonas acidovorans-arsenoxydans YE56 in various $0.1 \mathrm{M}$ phosphate buffers and the dissociaicin curves of arsentous actd and arsenic actd calculated from the dissociation constants. 


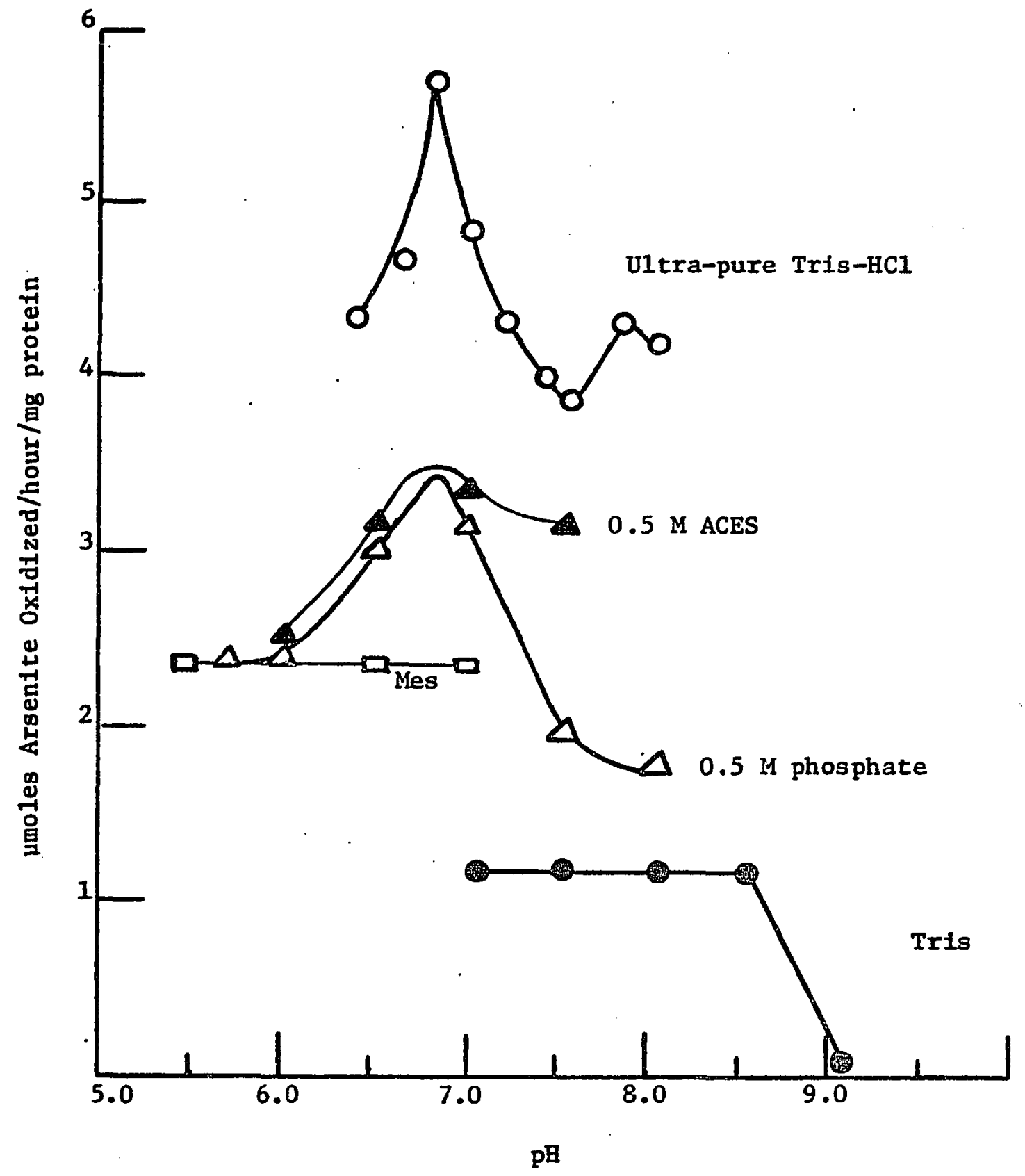

Figure 13. The pH optimum of washed cells of Pseudomonas acidovoransarsenoxydans YE56 in the presence of various buffers. 0.1 ml of washed cells in phosphate buffer $0.1 \mathrm{M}, \mathrm{pH} 6.6$ were added to $2.9 \mathrm{ml}$ of the buffer to be tested. Both initial and final $\mathrm{pH}$ were tested. All measurements were made at room temperature except ACES buffer which was tested at $32^{\circ} \mathrm{C}$. [0-0, $0.5 \mathrm{M}$ Tris; 0-0-0, $0.5 \mathrm{M}$ Ultrapure Tris-HCI; $\nabla-\nabla-\nabla$, $0.5 \mathrm{M}$ phosphate; $\square-\square, 0.5 \mathrm{M}$ Mes; $-1,0.5 \mathrm{M}$ Aces.] 

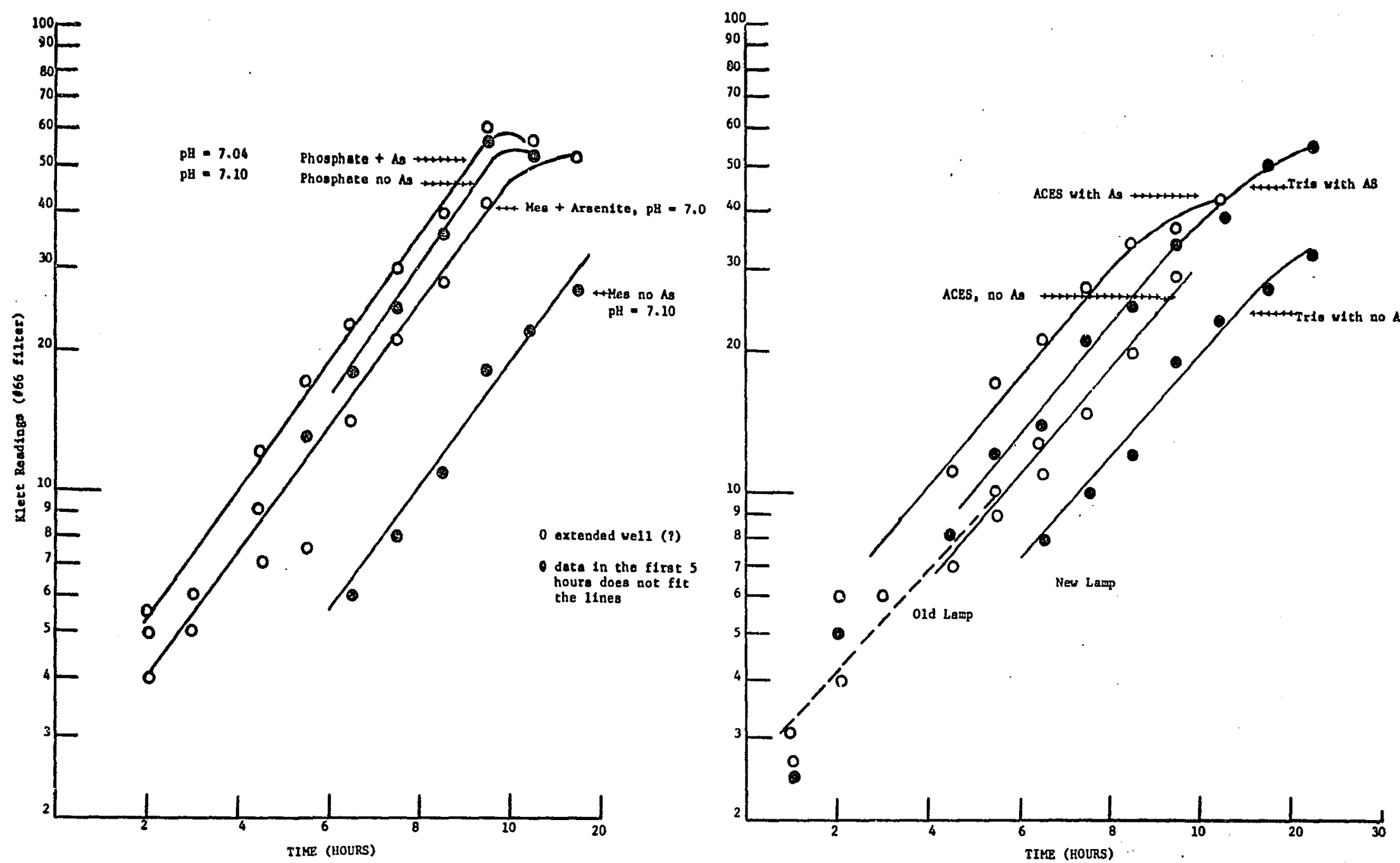

F1gure 14. The effect of various buffers in the presence and absence of arsent te on grouth of YE56. Experimental conditions: Temperature, $32^{\circ} C_{;}$Shake rate, 300 rpa calng 500 al flask her

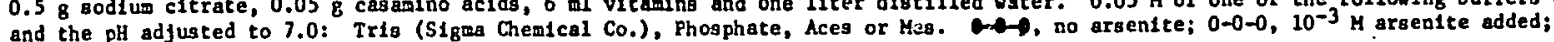




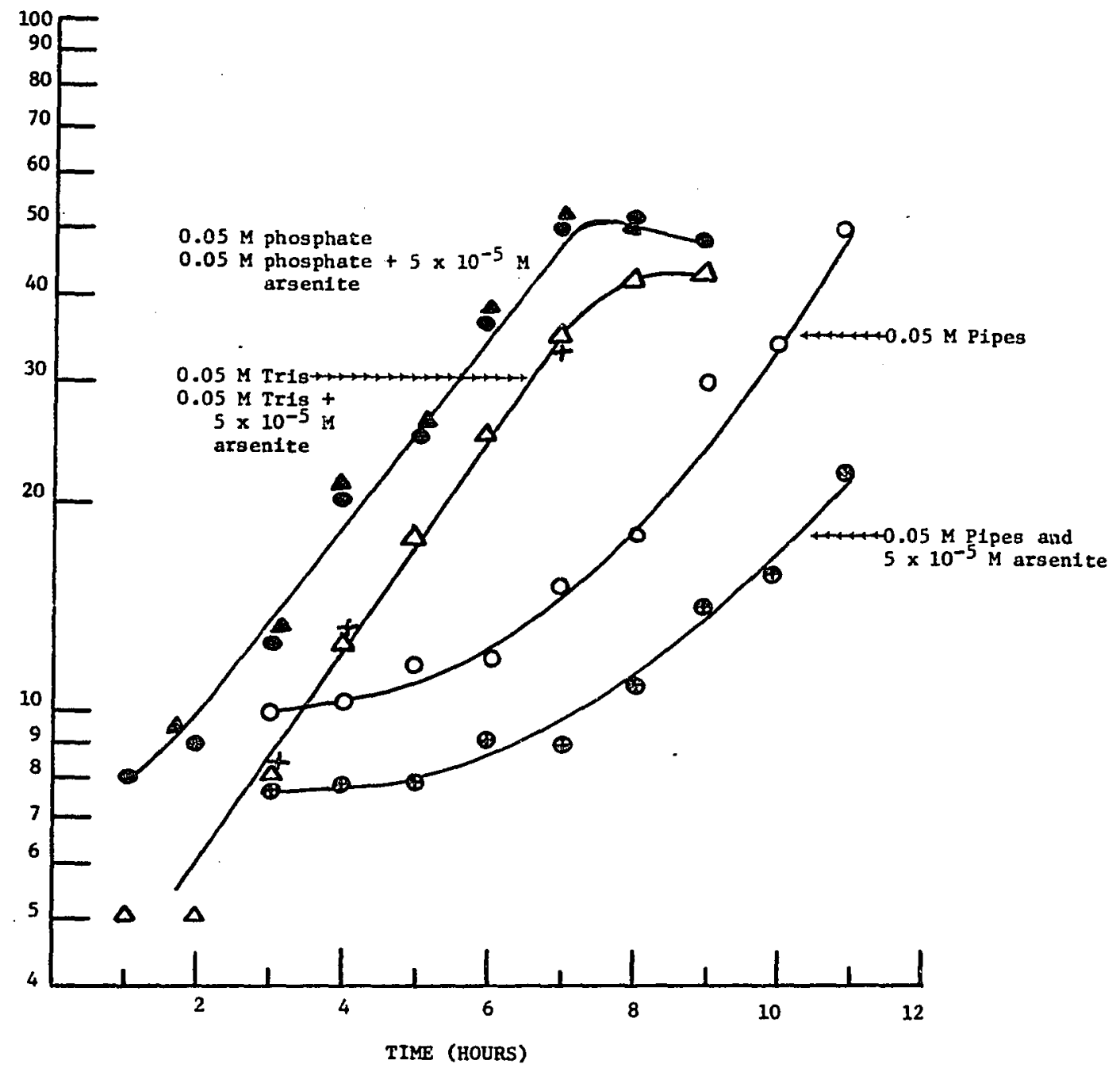

F1gure 15. The effect of various buffers in the presence and absence of arsentite on growth of YE56. Experimental conditions were the same as Figure 12 except: Temperature, $34^{\circ} \mathrm{C}$; Shake rate, $360 \mathrm{rpm}$ in flasks filled 20 percent of capacity $(0-0,0,0.05 \mathrm{M}$ phosphate and $Q, 0.05 \mathrm{M}$ phosphate plus $5 \times 10^{-5} \mathrm{M}$ axsenite, initial pH was 6.95; $\Delta-\Delta-\Delta, 0.05 \mathrm{M}$ Tris and Tris $\mathrm{HCl}$ and,$++-+ 0.05 \mathrm{M}$ Tris and Tris HCI plus $5 \mathrm{X}$ $10^{-5} \mathrm{M}$ arsenite, 1nitial $\mathrm{pH}$ was $7.35 ; 0-0-0,0.05 \mathrm{M}$ P1pes and $0-0-0,0.05 \mathrm{M}$ P1pes
plus $5 \times 10^{-5} \mathrm{M}$ arsen1te, Inftial $\mathrm{pH} 7.65$. 
TABLE XXIII

THE EFFECT OP GRONTH PH OS ARSENITE OXIDI2ENO

ACTIVITY IH GROWING CULTURES OP YES6

\begin{tabular}{|c|c|c|c|c|c|c|}
\hline & INITIAL pH & EINAL pH & $\begin{array}{l}\text { PINAL KLETT } \\
\text { READING }\end{array}$ & $\begin{array}{l}\text { PERCENT ARSENTTE } \\
\text { REMAINING }\end{array}$ & $\begin{array}{l}\text { PoTERTIN } \\
\text { ACrIVITY }\end{array}$ & $\begin{array}{l}\text { MFFETIV } \\
\text { ACrIVIT4 }\end{array}$ \\
\hline $\begin{array}{l}\text { Phthalnte } \\
\text { Phthelate } \\
\text { Phosphate }\end{array}$ & $\begin{array}{l}1.00 \\
5.00 \\
5.00 \\
5.50 \\
6.00 \\
6.25 \\
6.50 \\
6.75 \\
7.00 \\
7.25 \\
7.50 \\
7.75 \\
8.00 \\
8.25 \\
8.50 \\
8.75\end{array}$ & $\begin{array}{c}\text { Ho growth } \\
\text { No growth } \\
6.29 \\
6.45 \\
6.46 \\
6.50 \\
6.63 \\
6.64 \\
5.77 \\
6.29 \\
6.48 \\
6.62 \\
6.64 \\
7.09 \\
7.04 \\
7.40\end{array}$ & $\begin{array}{l}11 \\
13 \\
21 \\
22 \\
31 \\
36 \\
39 \\
39 \\
46 \\
49 \\
58 \\
51 \\
51 \\
-\end{array}$ & $\begin{array}{l}67.0 \\
83.0 \\
65.2 \\
59.5 \\
45.0 \\
26.4 \\
24.4 \\
42.5 \\
42.8 \\
49.4 \\
46.9 \\
75.5 \\
71.4 \\
-\end{array}$ & $\begin{array}{l}2.01 \\
9.24 \\
9.24 \\
8.04 \\
7.24 \\
7.24 \\
5.63 \\
5.23 \\
5.23 \\
5.23 \\
2.81 \\
1.61 \\
2.01 \\
0\end{array}$ & $\begin{array}{l}0 \\
3.62 \\
6.83 \\
8.04 \\
6.43 \\
6.83 \\
6.43 \\
4.02 \\
4.02 \\
4.02 \\
2.01 \\
1.61 \\
0 \\
0\end{array}$ \\
\hline $\begin{array}{l}\text { Borate } \\
\text { Borate }\end{array}$ & $\begin{array}{r}9.00 \\
10.00\end{array}$ & $\begin{array}{l}\text { No growth } \\
\text { No growth }\end{array}$ & & & & \\
\hline
\end{tabular}

106 filter

Estimated by lodometric titration with uninoculated arsenical modis tis 100 porcent

3 The activity of bacterta detertal ned at the optimua activity pil (In this case pH 6.6) and expraseed as

1d1zed per hour

The activity of bacteria detarthe aptiaum activity pH and expressed as micromoles arsenite oxidized per hour

Por determination of potential activity and effective activity coll suspengiong were adjusted to the oaso protein involved: 10 posalble to cospare the effect of treatmente without knowing the exact amount of 
the stationary growth phase. This indicates that the ablifty of cells to oxidize arsenite to arsenate is not a phosphate buffer dependent phenomenon.

Table XXIII shows that YE56 grows over a wide $\mathrm{pH}$ range and that the Inductbility of cells to oxidize arsenite, proceeds most rapidly at around $\mathrm{pH} 6.6$ although it is observed over a wide $\mathrm{pH}$ range. As indicated by the final klett readings, alkaline $\mathrm{pH}$ 's gave a higher cell yleld but the percentage of arsenite which had disappeared was lower than that obtained at approximately neutral pH. It appears that if the Initial $\mathrm{pH}$ of the growth medium is not too alkaline to prevent growth from starting, the slow oxidation of arsenite lowers the $\mathrm{pH}$ to more favorable levels for arsenite oxidation. The effective activity represents that portion of the potential activity which would actually be effective in the environment. The effective activity is fairly constant over the optimum growth range but falls off rapidly at the extreme buffer Iimfts. None of these variations occur in the absence of growth.

\section{Nutrition}

Growth. If an optimal nutritional medium is defined as one which gives the maximum growth rate or the maximum cell yield then a complex medium such as nutrlent broth with 3 percent yeast extract would be the medium of choice for this organism. The average cell yiedl using this mediun is 8 grams per liter. Figure 16 shows that yeast extract medium permits a higher level of arsenite oxidation than yeast extract plus succlnate or yeast extract plus citrate. (Yeast extract plus glycerol has approximately the same levels as yeast extract alone, as will be discussed subsequently, possibly because arsenite inhibits the glycerol kinase.) However, yeast extract (which contains amino acids, vitamins 
and muclelc acids) and nutrient broth both include unidentified nutrients and, therefore, are unsuitable for studies on bacterial metabolism. The following experiments were performed to define the best nutritional condftions given an essential mineral salts base, a comprehensive vitamin supplement and a knowledge of the required amino acids. Since any one of the essential nutritional requirements of an organism is a potentfal limiting factor, the composition of the medium was adjusted so that the concentration of all essential nutrients was in excess compared with a single nutrient which then became the sole limiting factor. In each case the growth conditions were as described in Materials and Methods, except for the single factor varied.

Preliminary experiments indicated a definite magnesium requirement for growth. Although all other mineral requirements could be satisfled by contaminants in reagents or on glassware, no growth occurred unless $\mathrm{Mg}+$ were present at a concentration greater than $10^{-6} \mathrm{M}$. Figure 17 shows that although the doubling times were independent of $\mathrm{MgH}$ concentration from $10^{-5}$ through $10^{-2} \mathrm{M}$, as the $\mathrm{Mg}+$ concentration increased from $10^{-4}$ to $10^{-2} \mathrm{M}$ the lag times increased. In addition a final $\mathrm{pH}$ of 6.84 was measured in cultures grown with $10^{-2} \mathrm{M} \mathrm{Mg}+$ in contrast to a final $\mathrm{pH}$ of 7.26 in cultures grown with $10^{-4} \mathrm{M} \mathrm{Mg}+$ indicating that the concentration of Mgth affects the pathway of respiration. The presence of $10^{-3} \mathrm{M}$ arsenite had no effect on the doubling time regardless of the concentration of $\mathrm{Mg}++$ in the culture.

The vitamin supplement as outlined in Materials and Methods can be supplied to a culture of YE56 at 6,8 , or $10 \mathrm{ml}$ per liter as seen in Table XXIV. Low or high concentrations limit the growth rate of the 


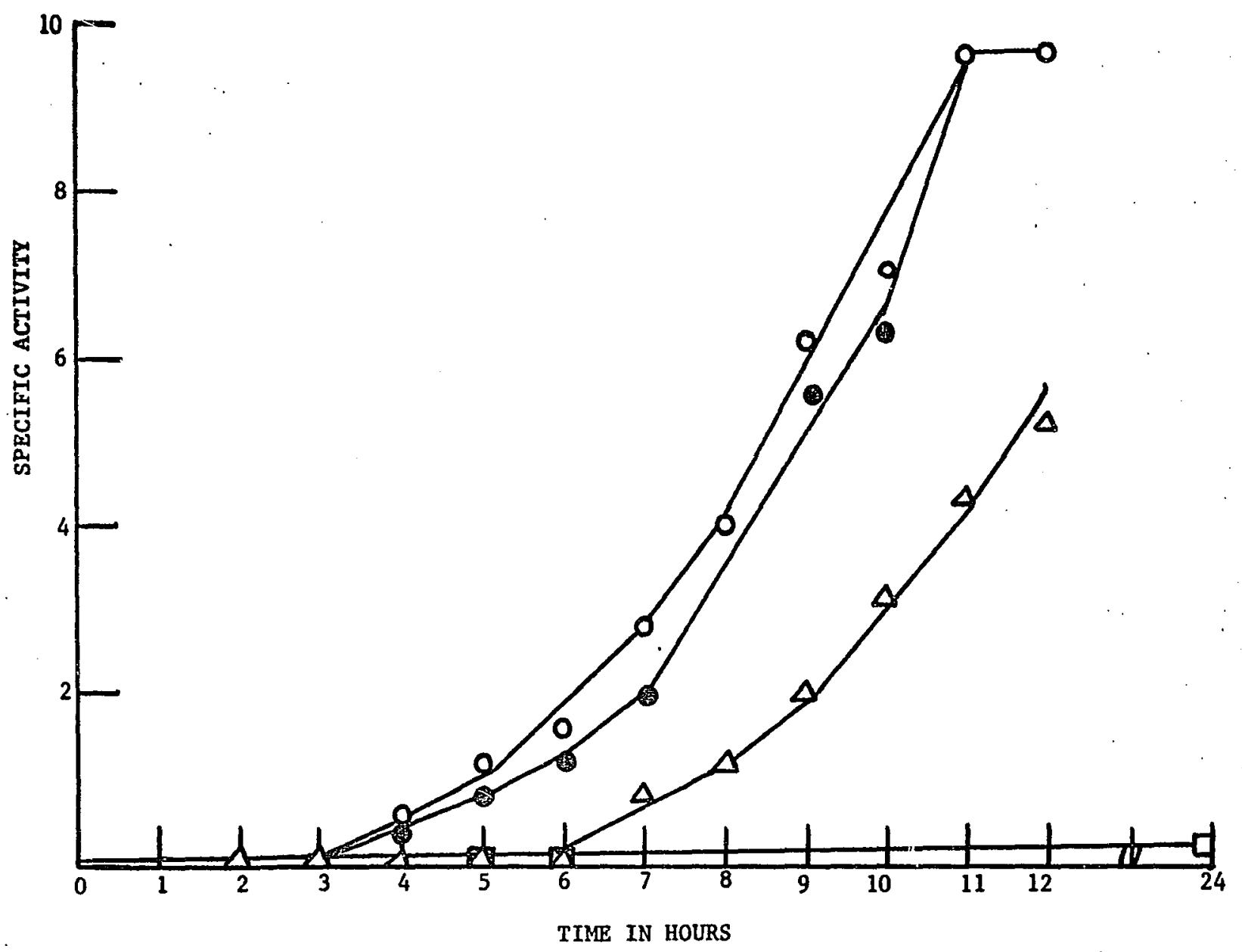

F1gure 16. Time course of the appearance of enzymes of arsenite oxidation after the addition of $0.01 \mathrm{M}$ sodium arsent te at zero time to a culture of Pseudomonas actdovorangarsenoxydans YE56. Specific activity is expressed as micromoles of arsente oxid1zed per hour per mg. protein. [0-0-0, CDM supplemented with $0.5 \mathrm{~g}$ yeast extract; $0-0-0$, CDM supplemented with 0.5 gram yeast extract and 0.5 gram glycerol: $\Delta-\Delta-\Delta$, CDM supplemented with 0.5 extract and $0.5 \mathrm{~g}$ citrate; $\square$, CDM supplemented 


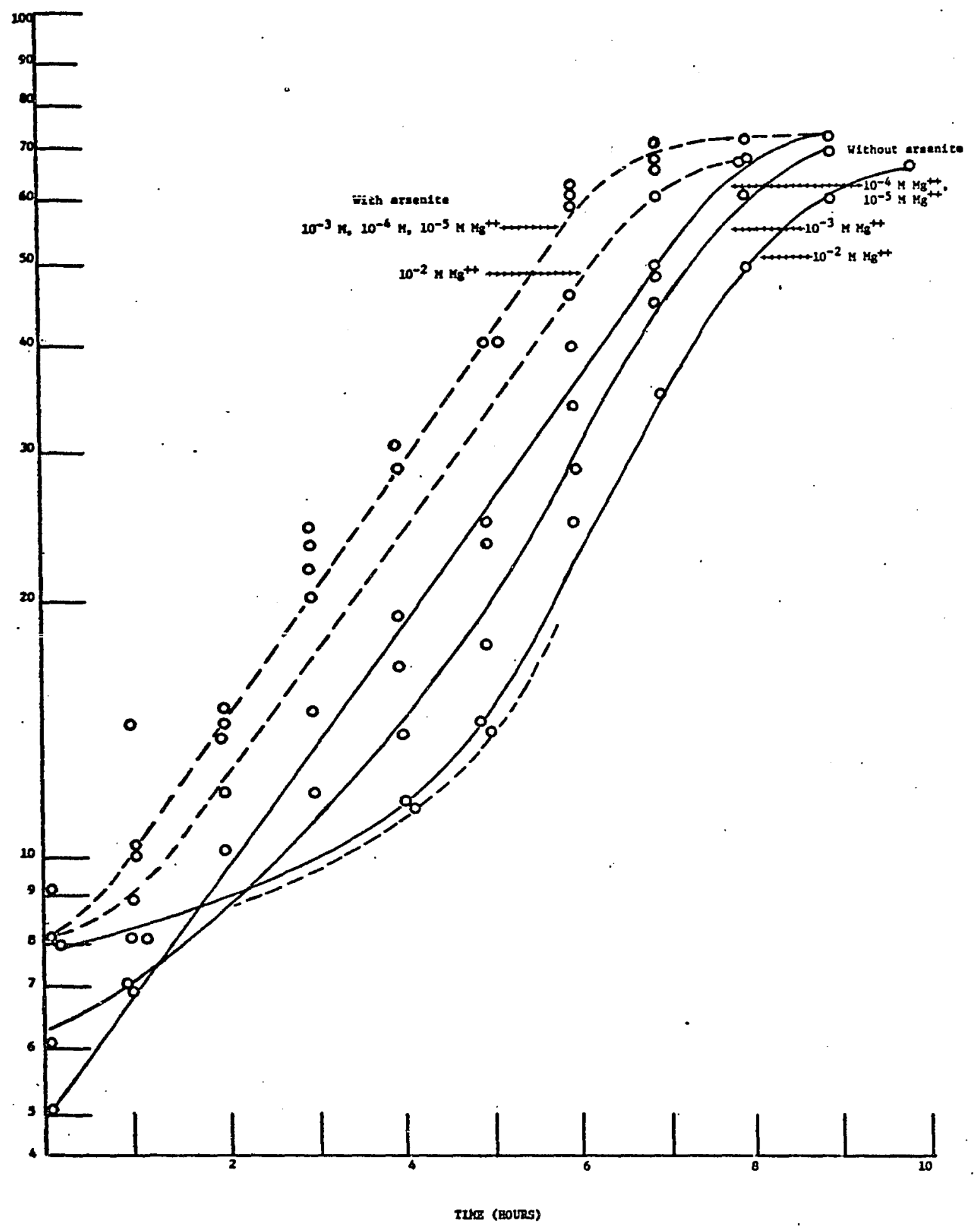

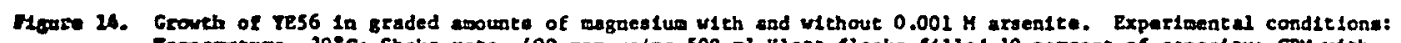

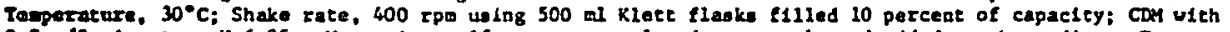
$0.5 \mathrm{~s} / 1$ citrate, pH 6.95. Magnesium sulfate vat autoclaved eeparately and added to the medium. Tea percent

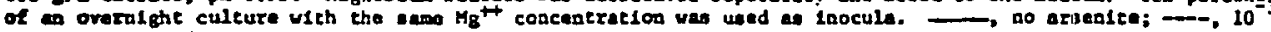
a areconte added. 
TABLE XXIV

THE EFFECT OF VITAMIN SUPPLEMENT ON THE DOUBLING TIME AND CELL YIELD

\begin{tabular}{cccc}
\hline $\begin{array}{c}\text { VITAMIN SUPPLEMENT } \\
\text { (ML PER LITER) }\end{array}$ & $\begin{array}{c}\text { GENERATION TIME } \\
\text { (min) }\end{array}$ & $\begin{array}{c}\text { CELL YIELD } \\
\text { (MICROGRAMS PROTEIN/ML } \\
\text { CULTURE) }\end{array}$ & $\begin{array}{c}\text { FINAL } \\
\text { pH }\end{array}$ \\
\hline 0 & 291 & 4 & 6.8 \\
2 & 156 & 21 & 7.2 \\
4 & 121 & 21 & 7.2 \\
6 & 90 & 19.5 & 7.2 \\
8 & 90 & 21 & 7.2 \\
10 & 96 & 21.5 & 7.2 \\
12 & 102 & 29.5 & 7.2 \\
\hline
\end{tabular}


organism; however, even with a lower growth rate the higher vitamin concentrations gave a larger cell yield. Six ml instead of $12 \mathrm{ml}$ as stated in Materials and Methods were chosen to supplement CDM for standard conditions in further studies.

In order to determine the smallest amount of vitamin-free acidhydrolyzed casein which would satisfy the essential amino acid requirements without providing an additional source of carbon and energy, varyIng amounts of casein were added to CDM containing 0.5 gram per liter sodium citrate. As seen in Figure 18, a nearly constant doubling time was obtained in the range 10 to 200 micrograms per ml casamino acids; at concentrations above 50 micrograms per ml casein can serve as an additional carbon and energy source as was determined by a larger final cell yield. Fifty micrograms per $\mathrm{ml}$ casamino acids were chosen for standard conditions so that a substrate being used as carbon and energy source could be the limiting factor.

Table XXV shows that at low concentration of citrate, the generation time increases with substrate concentration as might be expected. Under the growth conditions of this experiment, the fastest doubling time-was achieved with a level of approximately 250 gram per 1iter; above this concentration the generation time was increased. Therefore, In order to maintain cultures in the exponential growth phase by 1imitIng the amount of available energy source, 0.5 gram per liter of citrate was chosen for use in growth experiments under standard condtions. The effect of various carbon sources on arsenite oxidation was studled using CDM. Activity in Table XXVI Indicates that there is a direct relationship between generation time permitted by the carbon 


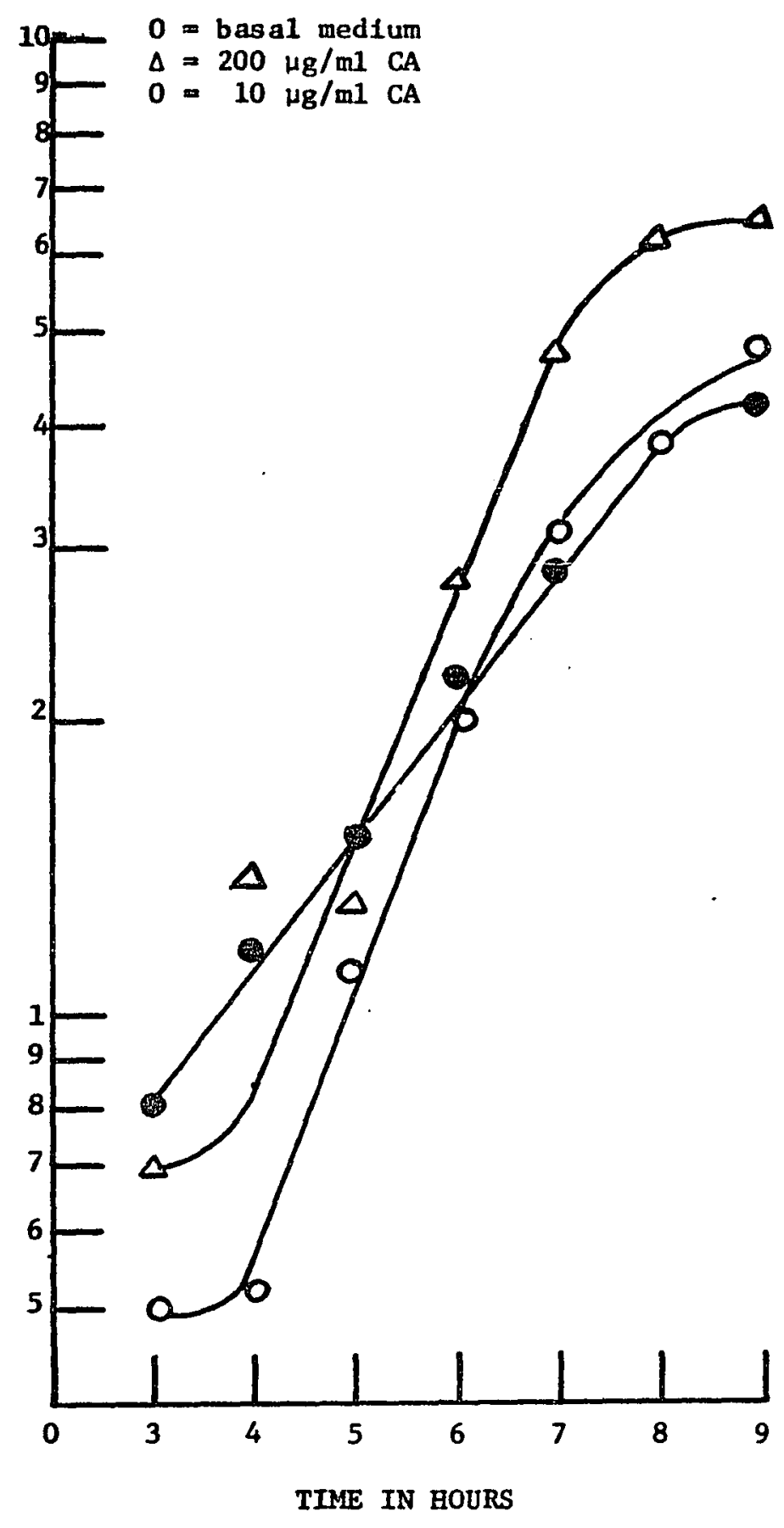

Figure 18. The effect of varying concentrations of casamino acids on doubling time and final cell yield in strain YE56. Experimental conditions: Temperature $37^{\circ} \mathrm{C}$; shake rate, $360 \mathrm{rpm}$; use $250 \mathrm{ml}$ flasks filled to 20 percent of capacicy; CDM containing $0.5 \mathrm{gram} / 11$ ter $\mathrm{Na}$ citrate and caseamino acid supplement as indicated. [ $0=\mathrm{CDM} ; \Delta=200 \mu \mathrm{g} / \mathrm{ml}$ caseamino acids; $0=$ $10 \mu g / m l$ casamino acids] 
TABLE XXV

THE EFFECT OF VARYING CONCENTRATIONS OF SODIUM CITRATE ON THE GROWTH RATE AND GENERATION TIME OF PSEUDOMONAS

ACIDOVORANS-ARSENOXYDANS YE56

\begin{tabular}{cccc}
\hline $\begin{array}{c}\text { CONCENTRATION SODIUM CITRATE } \\
\text { grams/1iter }\end{array}$ & $\begin{array}{c}\text { GROWTH RATE } \\
\text { (gen/hr) }\end{array}$ & $\begin{array}{c}\text { GENERATION } \\
\text { TIME } \\
\text { (min) }\end{array}$ & $\begin{array}{c}\text { FINAL } \\
\text { pH }\end{array}$ \\
\hline 0 & No growth & - & 6.80 \\
0.05 & 0.233 & $258 \mathrm{~min}$ & 6.82 \\
0.10 & 0.556 & $108 \mathrm{~min}$ & 6.87 \\
0.50 & 0.715 & $84 \mathrm{~min}$ & 7.10 \\
1.0 & Broken & - & 6.76 \\
2.5 & 1.000 & $60 \mathrm{~min}$ & 6.93 \\
3.75 & 0.625 & $96 \mathrm{~min}$ & 7.07 \\
5.00 & 0.400 & $138 \mathrm{~min}$ & 7.00 \\
& & & \\
\hline
\end{tabular}


TABLE XXVI

ACTIVITY OF ARSENITY OXIDIZING SYSTEM GROWN IN DIFFERENT CARBON SOURCES

\begin{tabular}{lcc}
\hline SUBSTRATE & $\begin{array}{c}\text { GENERATION TIME } \\
\text { (minutes) }\end{array}$ & $\begin{array}{c}\text { SPECIFIC ACTIVITY } \\
\text { (Micromoles arsenite } \\
\text { oxidized/hour/mg } \\
\text { protein }\end{array}$ \\
\hline Citrate & 93 & 2.14 \\
Succinate & 108 & 2.44 \\
Glutamate & 150 & 4.46 \\
d-Retoglutarate & 180 & 6.38 \\
\hline
\end{tabular}

Experimental conditions: Inocula were from overnight cultures grown in the same carbon source. Cultures were grown for at least one generation before $0.01 \mathrm{M}$ arsenite was added to one of two identical flasks. The $\mathrm{pH}$ was adjusted to that of the duplicate. Activity was measured 60 minutes after its detection. Generation time was estimated by increase in absorbance using a Klett Summerson colorimeter with a 非6 filter. 
source and the arsenite oxidizing activity. Although not shown in Table XXIV, acetate was used as a carbon source in this experiment but It could not be compared with the other carbon sources because growth never entered the logarithmic growth phase and arsenite oxidizing activity had not appeared by the time the experiment was terminated. It appears that the longer the generation time the greater the specific activity for arsenite oxidation when the cells reach the stationary growth phase.

A sma11, but consistent, drop in absorbance was always observed Immediately after the cells entered stationary phase. As can be seen In Figure 19 when normal logarithmic growth was stopped by exhaustion of limiting substrate, at early stationary phase there was an initial $10 s 8$ of turbidity followed by a terminal phase of lysis so that turbidity was substantially reduced 24 hours after inoculation. FIgure 20 shows that a loss of viability precedes cell lysis since the absorbance remained high while viable count decreased rapidly. In this experiment the culture was removed from the shaker at statlonary phase and allowed to remain unaerated until the end of the experiment. Observations made In other experiments in which cultures were kept on the shaker after reaching stationary phase showed that viability decreased in proportion to the gradual decrease in absorbance. The loss in viability could not be correlated with a change in $\mathrm{pH}$. It can be seen in Figure 21 that the diluent used to estimate the viable count determined the shape of the curve obtained.

Since the drop in turbidity coincided with exhaustion of substrate, it was postulated that magnesium Ions formed bridges between 


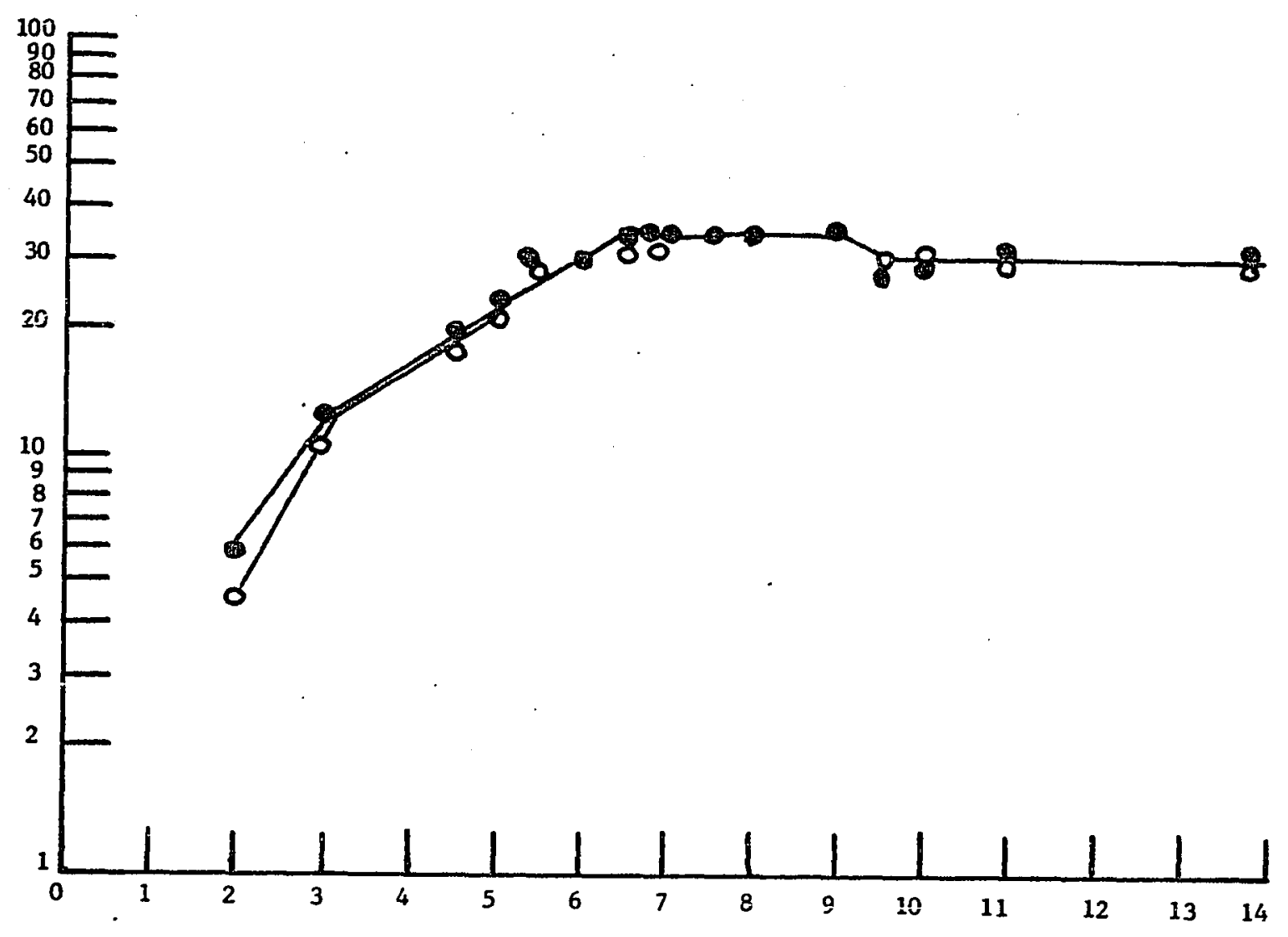

TIME IN HOURS

F1gure 19. Growth curve of Pseudomonas acidovorans-arsenoxydang YE56 with and without the addition of arsenite. Experimental conditions: Temperature $32^{\circ} \mathrm{C}$; Shake rate, $360 \mathrm{rpm}$ using $500 \mathrm{ml}$ flasks filled to 20 percent of capacity with CDM containing with $0.5 \mathrm{~g} / 1$ citrate. Turbidity was measured in a glett-Sumerson colorimeter using a \#66 filter. [0-0-0, no arsenite; $0-0-0,10^{-3} \mathrm{M}$ arsenite.] 


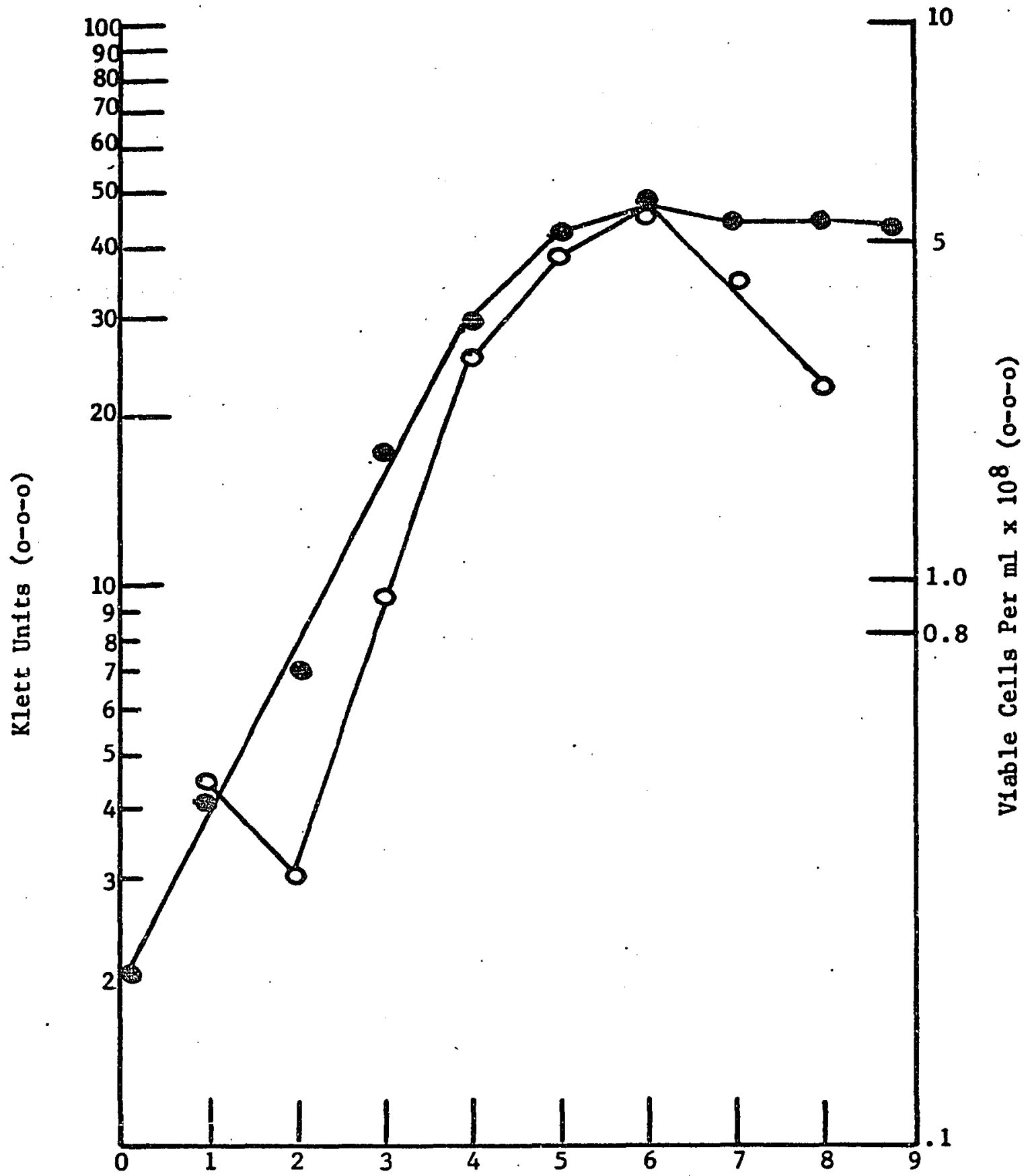

Figure 20. Growth of Pseudomonas ac1dovorans-arsenoxydans YE56 measured by viable cell count $(\theta-\theta-\theta)$ and turbidity (o-0-0) showing lysis at early stationary phase. Experimental conditions: Temperature, $37^{\circ} \mathrm{C}$; Shake rate, $400 \mathrm{rp}$; CDM w1th $100 \mathrm{micrograms} / \mathrm{ml}$ aspartate and 0.5 grams per ml sodium citrate, Initial pH 6.8; Final pH, 7.4. Medium contained no arsenic. Turbidity measured In a Klett-Summerson colorimeter using a 非6 f11ter. 


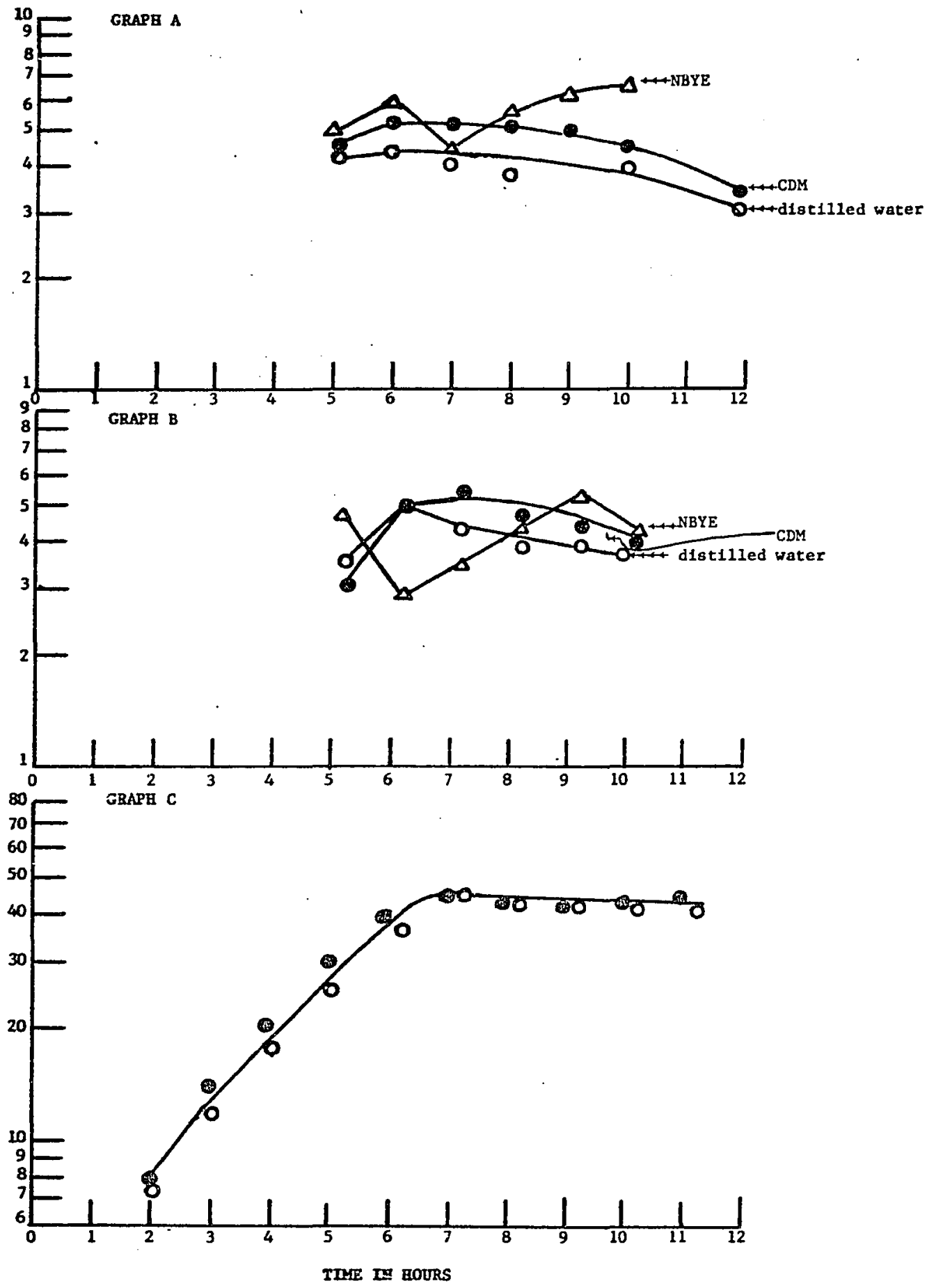

F1gure 21. Dependance of cell viability on diluent composition. Cells were grown at $32^{\circ} \mathrm{C}$ using 2 11.er flasks containlng CDM with 0.5 grams/11ter soldium citrate. One flask contained no arsente; Initial $\mathrm{pH} 6.9$, final $\mathrm{pH} 7.3$. A second flask contained $10^{-3} \mathrm{M}$ oadtum arseafte, Initfal pH 6.9. final pH 7.2. When the cells reached late log phase, dilutlons were made 1nto NBYE $(A-A-A)$, CDM without c1trate to prevent substrate accelerated death $(0-0)$, and distilled water (0-0); pour places were made into NBYE agar medium. viable cell counts shown in " $A$ " were obtalued from cells grown in CDM containing citrate and arsenite. Graph "B" shows the viable cell count for cells grown in CDM containing cltrate but no arsenite. 
anionic groups in the cell envelope and that a cation such as sodium ions should be able to displace the magnesium lons making the cell more susceptible to lysis as shown by DeVoe and Oginsky, (1969). In the case of YE56 it was proposed that interaction of monovalent and divalent cations caused a disorganization of the envelope resulting in increased non-selective permeability and thus loss of viability. The increasing non-selective permeability would lead to a progressive deterioration of the cell wall-envelope proceeding to ultimate rupture (lysis). In order to test this hypothests cells were grown in CDM containing $1.7 \mathrm{mM}$ magnesium Ions to the late log phase. Cultures were then supplemented with $10^{-1} \mathrm{NaCl}, 10^{-1} \mathrm{KCl}$ or $10^{-2} \mathrm{M} \mathrm{MgSO}_{4} \cdot 7 \mathrm{H}_{2} 0$; distilled water was added to the control culture. If the hypothesis was correct, those cultures receiving supplements should not lyse because there would be an adequate concentration of cations to maintain shielding of the envelope-anionic groups and thus prevent envelope disintegration. But the control culture should undergo the typical change in absorbancy. As seen from Figure 22 the results were not as predicted; the salts had no effect on lysis except to change the Iytic pattern.

In another experiment $0.25 \mathrm{ml}$ of a cell suspension obtained from stationary growth phase was added to each of a series of matched tubes which contained $9.75 \mathrm{ml}$ of several salts in varying concentration. Readings were taken every $10 \mathrm{~min}$. for 2 hours. When the cell suspension (which had been pre-exposed to 1.7 mil magnesium Ions in CDM) was diluted Into $0.1 \mathrm{M}$ phosphate buffer, $\mathrm{pH} 6.8$, containing $1.7 \mathrm{mM}$ magnesium ions, there appeared to be a protective effect. In contrast, cells which had been diluted into $0.1 \mathrm{M}$ phosphate buffer only or into $0.1 \mathrm{M}$ phosphate 

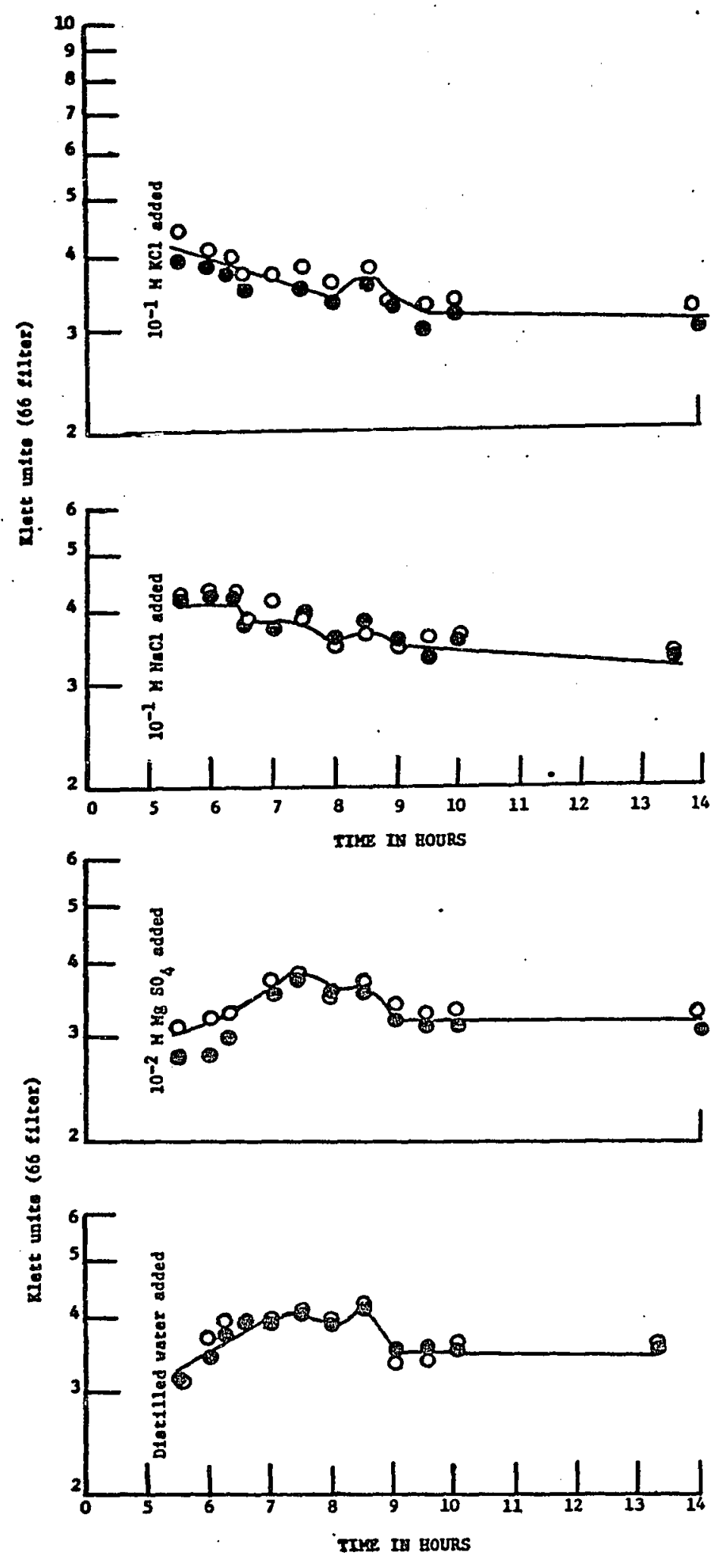

71gure 22. Lytle pattern of stationary grouth phase with the addition of various 10ns. Experimental conditions: Cells were of various $32^{\circ} \mathrm{C}$ us ing 400 on $\mathrm{klett}$ flasks filled 20 percent of capactity on a gyrcrotory shaker at $360 \mathrm{IPM} ; \mathrm{CDM}$ w1th $0.5 \mathrm{~g} / 1$ cierate. $0, n-0=$ no arsenite; $0-0-0=10^{-3} \mathrm{M}$ arsenice added. 
buffer containing various concentrations of NaCl or KCL showed an accelerated loss of viability. It would appear from these experiments that factors other than that of ionic ratio were more important in the maintenance of cell integrity and. induction of arsenite oxidation. As shown by Ellwood and Tempest (1967) the medium and the growth rate are extremely Important in cell integrity and metabolism.

During the course of these experiments, it was observed microscopically that the cells went from small rods in exponential phase to aimost coccoid-shape during early stationary. Thus the small drop in absorbancy which always was observed immediately after the cells entered stationary phase (and which has previously been noted by Koch, 1961) definitely correlates with the visible change in cell size and does not indicate a loss of viability as had previously been assumed.

As shown in Figure 23 arsenite oxidation by Pseudomonas actdovorans-arsenoxydans YE56 is brought about by an induced enzyme and/or electron acceptor which is formed only when the cells are grown in the presence of arsenite. The failure of YE56 to oxidize arsenite could be due to the impermeability of the cell to arsentte rather than the absence of an arsenite oxidizing system, but Figure 23 shows that the enzyme system is not constitutive lacking only the permease. The ability of YE56 to induce arseñtie oxidation was independent of arsenite in the stocking medium. Arsenate could not replace arsenite as Inducer except in one instance where a mutant was found to arise during an experiment designed to determine the effect of arsenate on the growth rate.

Potassium tellurite, sodium sulfite and sodium nitrite at two 

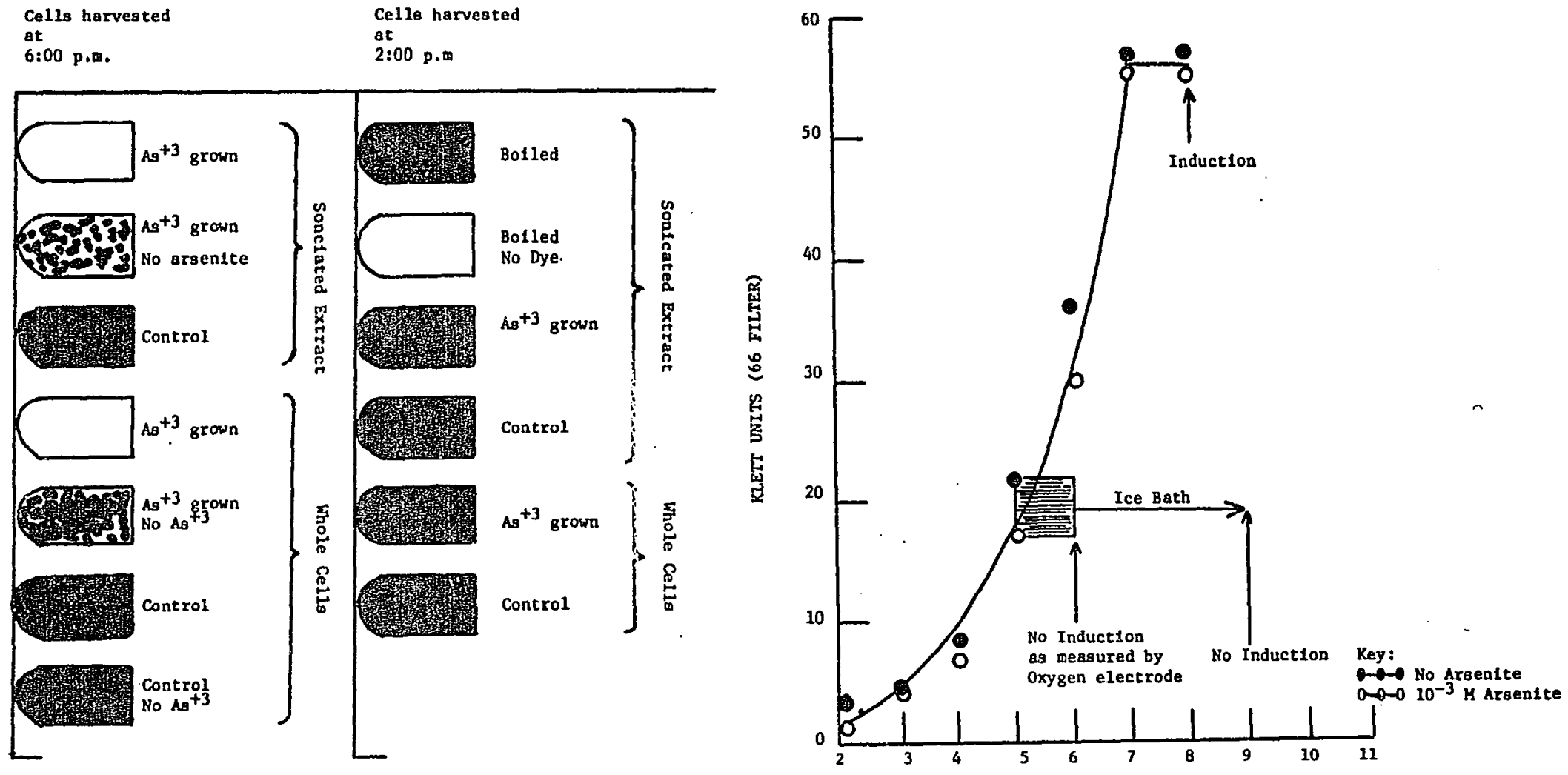

F1gure 23. Diagram ghowing that the arsenite-oxidizing system of Pseudomonas acldovorans-arsenoxydang strain YES6 18 induced. Two hundred mi of the culture was grown at $32^{\circ} \mathrm{C}$ in a 2 liter erylenweyer flask at 320 without arsenite had an initial pH of 6.9; medium with $10^{-3}$ arsenite had an initial $\mathrm{pH}$ of 6.7. Cells were harvested in early log phase and stationary phase by allipore flltering. Each culcure harvegt was resuspended to 10 wl w1th $0.1 \mathrm{M}$ phosphate buffer, pII 5.8 and divided Into two $5 \mathrm{ml}$ all fuots which were stored in an ice bath. One aliquot of each pair was sonicated. For assay each thumberg tube contalned $2 \mathrm{ml}$ of cel 2.6 dichlorophenolindophenol, and where

buffer, $\mathrm{pH} 6.8,0.5 \mathrm{ml}$ of 2,6 dichlorophenolindophenol, and where 
different levels $\left(5 \times 10^{-4} \mathrm{M}\right.$ and $\left.2.5 \times 10^{-4} \mathrm{M}\right)$ were added to media containing concentrations of arsenite ranging from $5 \times 10^{-6}$ to $5 \times 10^{-2}$ in order to determine their ability to competitively inhibit arsenite oxddation by the oxygen probe method. (These substrates were also tested by the Thunberg method using sonicated cell extracts.) No inhibition of arsenite oxidation was found under any of the conditions tested.. Also, tellurite, sulfite or nitrite could not serve as an alternative substrate for arsenite. However, YE56 could be induced to sulfite oxidation by growing cultures in the presence of $0.02 \mathrm{M}$ sulfite Instead of arsenite. Two different levels of arsenite were tested against varying concentrations of sulfite added to intact cells induced for sulflte oxidation; the arsenite had no effect on sulfite oxidation. Therefore, it can be concluded that the arsenite and the sulfite oxidizIng systems are each specific for their inducer and substrate. This is In direct contrast to Challenger and Higginbottom (1945) who found that fung1 which could methylate arsenite could also methylate tellurite and selenite.

When cells which had been grown previously in the absence of arsenite were grown in the presence of $10^{-2}$ or $10^{-3} \mathrm{M}$ arsenite, there was always a Iong lag period, generally 2 to 3 hours before any arsenite oxidation could be detected by the oxygen probe method or TLC. When cultures: were grown in a rich medium arsenite oxidizing activity could be detected while the culture was in exponential phase growth (Figure 16) but in CDM arsenite oxidizing activity was first detectable at early stationary phase and remained constant for at least 12 hours under conditions where no cell lysis occurred. When cells were examined 
to see if they contained the arsenite oxidizing enzyme throughout the growth eycle, half the culture was millipore filtered at early exponential phase and the remainder filtered at stationary phase (Figure 2.3). The early exponential phase celis showed no arsenite oxidizing activity by either the oxygen probe or Thunberg method. Induction could be prevented in these cells by freezing; or delayed, so that after 4 days storage in an ice bath, only a questionable rate of oxygen uptake could be detected. Thus the arsenite oxidizing induction probably occurs due to some cell differentiation which occurs at the onset of the stationary phase.

Infefally inducer was present in saturating concentrations as will be shown subsequently. Since we were unable to find a gratuitous inducer for the arsentte oxtdizing enzyme, arsenite concentrations did not remain constant. As a consequence the rate of synthesis of enzyme relative to total protein synthesis (Figure 24) were not constant at high bacterial concentrations probably due to the reduction of arsenite concentration below saturating level. A constant differential rate of enzyme synthesis from the moment of addition of inducer is evidence that inducer is present in saturating concentrations and that conditions of metabolic and induction gratuity exist (Coh, 1957). Whether or not the conditions of induction gratuity were met could not be determined from designed experiments. However, there was the possibility that the long Iag periad reflected release from catabolite repression. Preliminary experiments using the technique of reversal of catabolite repression by cyclic AMP (Perlman et al., 1969; Botsford and DeMoss, 1970) failed because treatment of cells with ethylenediamine tetraacetic acid (EDTA) to 


\section{Klett Unter}

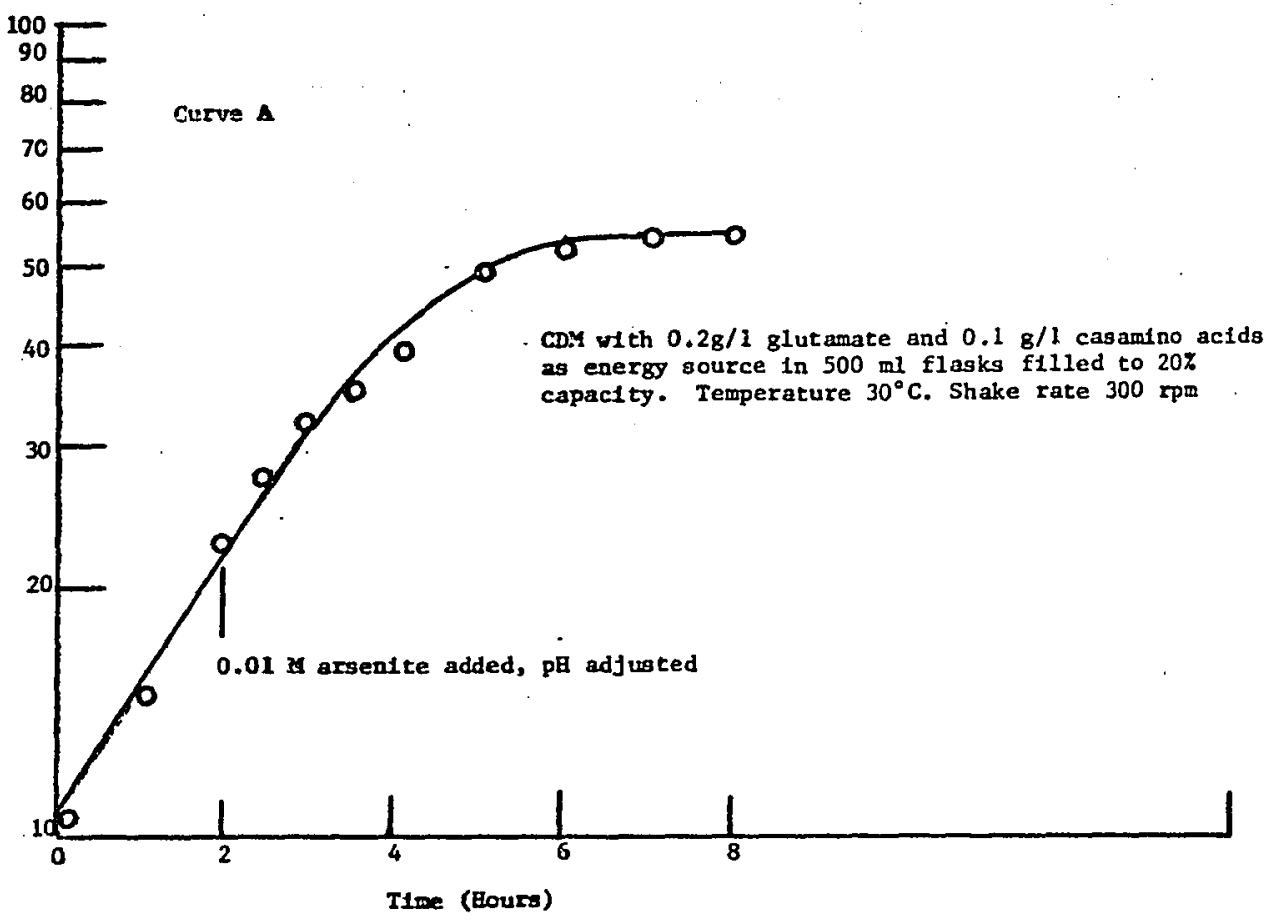

Micromoles oxpgen consuned/minute/liter

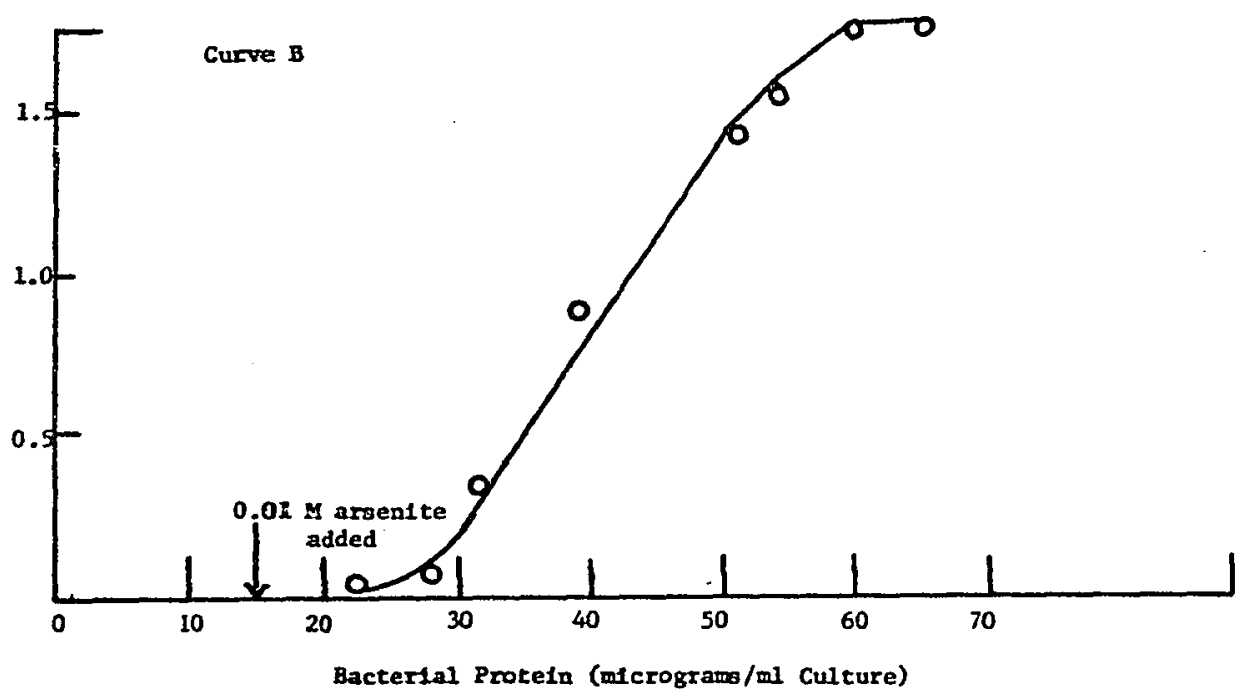

Figure 24. Induction of arsente axtdizlng capacity in an exponentially grosing, previously nondaduced culture of Pseudomonas ac1dovorans-arsenoxydans YE56. Curve A shows the addition of inducer to an exponentially growing culcure fust entering stationary the add Curve $B$ shous the amount of oxygen consumed in the presence of sodiun arsenite phase. Curve B shous the amount of oxygen constelons: Temperature $30^{\circ} \mathrm{C}$, Shake rate versus mg bacterial proteln. Experimental conditions: Temperats as carbon and energy $300 \mathrm{xpm}$, coet with $0.2 \mathrm{~g} / 1 \mathrm{glutamate}$ and $0.1 \mathrm{~g} / 1$ casamino acids " $\mathrm{I}$ ", $0.01 \mathrm{M}$ arsent te was added to the culture and the $\mathrm{pll}$ adfusted. 
increase permeability to cyclic AMP resulted in death of the culture. Table XXVII presents evidence suggesting that catabolite repression is not the cause of the long lag period; therefore, this long lag period is probably due to an undefined change in YE56 at stationary phase as previously discussed.

Since the ability of YE56 to oxidize arsenite was correlated with the entry of the cells into stationary phase, the possibility that the enzyme responstble for arsenite oxidation was being released into the medium upon lysis of the cells at the stationary growth phase was tested in the following manner: Cells growing in CDM under standard conditions were transferred into fresh medium containing $0.02 \mathrm{M}$ arsenite. At one hour intervals samples were taken, optical density was measured in Bausch and Lomb Spectronic 20 at $660 \mathrm{~nm}$ and viable counts were made at each time point. Samples were filtered through a 0.45 micron millipore filter. An alfquot of the filtrate was used to determine the amount of arsenite remaining, and the remainder of the filtrate was incubated under the same experimental conditions as the original culture. At the end of the experiment each filtrate was again titrated to determine the amount of arsenite remaining. As can be seen in Table XXVIII, the amount of arsenite did not decrease in the incubated filtrate as would be predicted had an enzyme been liberated into the medium. When a culture showing maximum arsenite oxidizing activity was millipore filtered, all the arsenite oxidizing activity was found to reside in the cells with no activity in the filtrate.

Figure 25 shows that arsentte oxidation in growing cells results In a concomitant decrease in $\mathrm{pH}$, even in a medium containing the 
TABLE XXVII

EFFECT OF SUBSTRATE ADDITION ON ARSENITE OXIDIZING ACTIVITY

IN PSEUDOMONAS ACIDOVORANS-ARSENOXYDANS YE56

\begin{tabular}{|c|c|c|c|c|c|c|}
\hline \multirow[b]{2}{*}{$\begin{array}{l}\text { Time in } \\
\text { Hours }\end{array}$} & \multicolumn{2}{|c|}{ CONTROL } & \multicolumn{2}{|c|}{ ARSENITE } & \multicolumn{2}{|c|}{$\begin{array}{l}\text { ARSENITE + ADDED CITRATE } \\
\text { AT } 7 \text { HOURS }\end{array}$} \\
\hline & $\begin{array}{l}\text { Klett } \\
\text { Units }\end{array}$ & Velocity* & $\begin{array}{l}\text { Klett } \\
\text { UnIts }\end{array}$ & Velocity* & $\begin{array}{l}\text { Klett } \\
\text { Units }\end{array}$ & Veloctty* \\
\hline 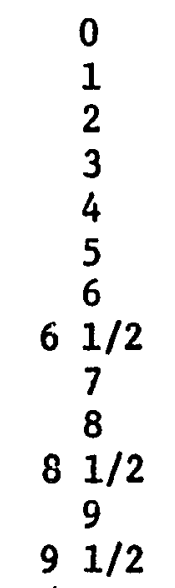 & $\begin{array}{c}2 \\
3 \\
7 \\
16 \\
26.5 \\
42 \\
45 \\
- \\
46 \\
50 \\
- \\
42 \\
-\end{array}$ & $\begin{array}{l}- \\
- \\
- \\
- \\
- \\
- \\
0 \\
- \\
0 \\
0 \\
0 \\
-\end{array}$ & $\begin{array}{r}3 \\
3 \\
9 \\
18 \\
26 \\
42 \\
45 \\
50 \\
49 \\
50 \\
45 \\
45 \\
49\end{array}$ & $\begin{array}{l}- \\
- \\
- \\
- \\
- \\
- \\
1.83 \\
1.83 \\
1.83 \\
1.83 \\
1.83 \\
- \\
-\end{array}$ & $\begin{array}{l}46 \\
47 \\
50 \\
60\end{array}$ & $\begin{array}{l}2.33 \\
2.50 \\
2.75 \\
2.50\end{array}$ \\
\hline
\end{tabular}

Experimental conditions: Temperature, $32^{\circ} \mathrm{C}$; Shake rate, $360 \mathrm{rpm}$ using 2 liter erylenmeyer flasks filled 15 percent of capacity with CDM containing $0.5 \mathrm{~g} / 1$ citrate, initial $\mathrm{pH} 6.92$ (control) and CDM with $0.5 \mathrm{~g} / 1$ citrate plus $10^{-3} \mathrm{M}$ arsenite, $\mathrm{pH}$ adjusted to 6.92 . After 7 hours the flask containing arsenite was sp1it Into two $100 \mathrm{ml}$ aliquots using $500 \mathrm{ml}$ Klett flasks and 0.05 grams of citrate was added to ore flask and the $\mathrm{pH}$ adjusted to that of the other half. A number 54 filter was used in the Klett.

* Percent oxygen consumed per minute $1 \mathrm{n} 3 \mathrm{ml}$ of culture. 


\section{TABLE XXVIII}

THE EFFECT OF CULTURE FILTRATE ON ARSENITE OXIDIZING ACTIVITY

\begin{tabular}{ccccc}
\hline $\begin{array}{c}\text { VIABLE } \\
\text { TOURS }\end{array}$ & $\begin{array}{c}\text { COUNT } \\
\text { X } 10^{8}\end{array}$ & $\begin{array}{c}\text { OPTICAL } \\
\text { DENSITY* }\end{array}$ & $\begin{array}{c}\text { PERCENT ARSENITE REMAINING IN FILTRATE** } \\
\text { TESTED } \\
\text { IMMEDIATELY }\end{array}$ & $\begin{array}{c}\text { TESTED AT END } \\
\text { OF EXPERIMENT }\end{array}$ \\
\hline 0 & 3.64 & .28 & 100 & Not tested \\
1 & 2.91 & .37 & 83 & 50 \\
2 & 3.60 & .42 & 4 & 0.5 \\
3 & 5.87 & .50 & & 0.5 \\
\hline
\end{tabular}

* Bausch \& Lomb Spectronic 20 Colorimeter at 660 nanometers

** Estimated by 1odometric titration 
Eote Date (166 F11ter)
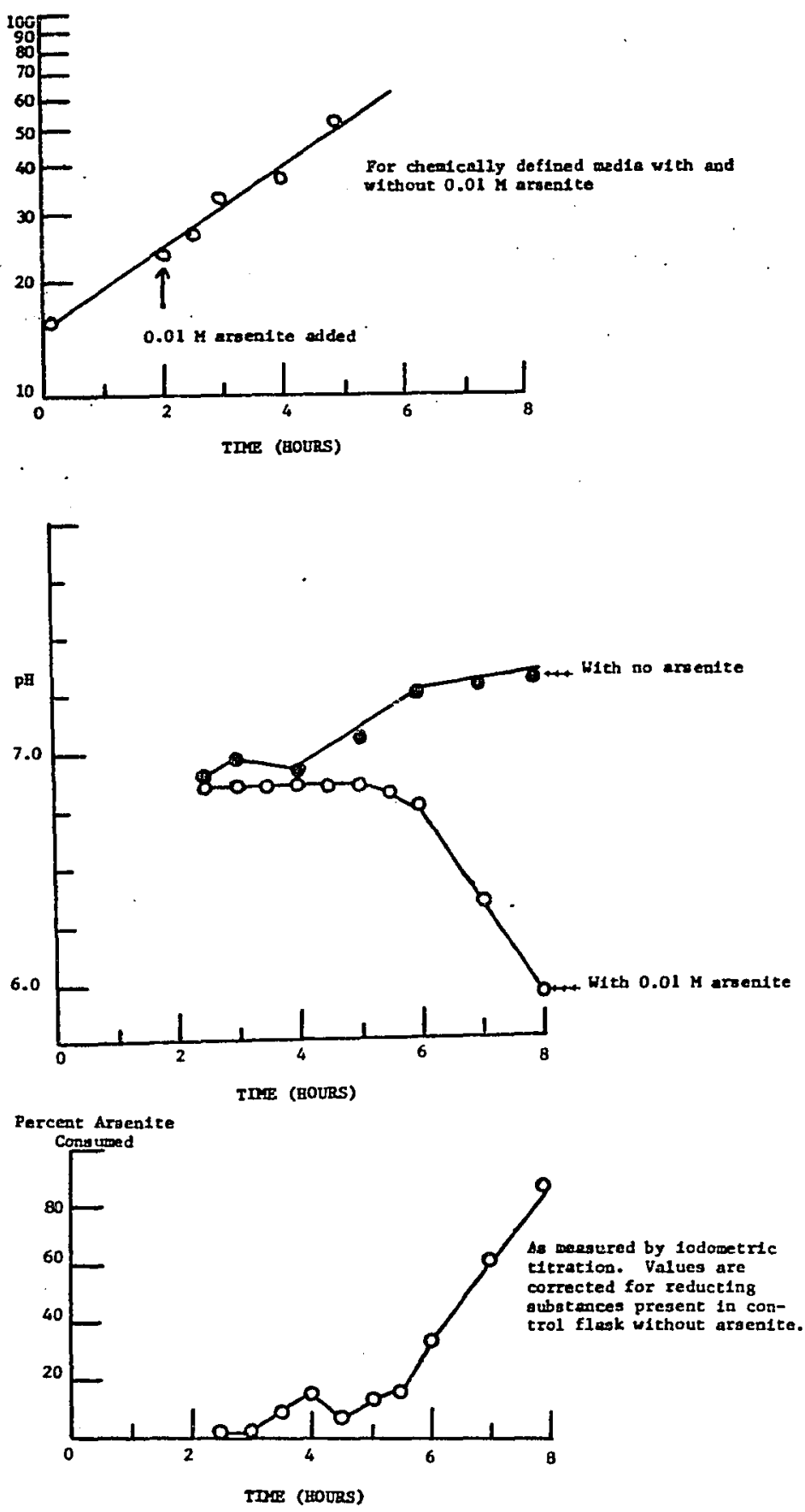

Figure 25. Relationsh1p batween grouth, argenite oxidation and pl. Experimental conditions: Temperature, $33^{\circ} \mathrm{C}$; Shake rate 320 xpp us ling 2 liter erylenmeyer flagks filled 20 percent of capacity with CDM containing 0.3 gram per liter sodium glutemate. Turb 1dity measured using a klett-Sumeraon colorimeter waing a filer [ph of medium $y$ th no araente

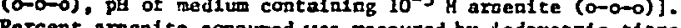
Percent arsent te coasumed uas me asured by lodometric titro tion. Values are corrected for reducing abstances present In control flssik without arsentice. 
buffering of phosphate, citrate, and amino acids. Assuming that all the carbon source is oxidized to carbon dioxide and water (and disregarding the small change in $\mathrm{pH}$ due to carbonic acid) the final $\mathrm{pH}$ of a O.0̂I î̀ carbon (sodium citrate) Inorganic salts medium should approach 7.60 (experimentally the $\mathrm{pH}$ was found to be 7.55). Since nitrogen is supplied as an ammoniun salt in CDM, the utlifzed ammonia leaves in the medium a corresponding amount of free acid (Munro, 1970). In addition metabolism of either Ion of the phosphate buffer will lead to changes In the $\mathrm{ph}$ of the culture by upsetting the existing ratios of acid and salt molecules. Therefore, it seems that the predicted value of 7.60 may be too high. The increased acidity could be accounted for by arsenite interference with metabolism and the consequent excretion of an acidic product and/or by the Immediate release of arsenate which is much more dissociable than arsenite. ThC procedures (Eastman Chromatogram System Analytic Procedures) for the detection of amino acids, lipids, dibasic acids and carbohydrates were exhaustively carried out to find such an acidic metabolite. None was detected. Figure 26 shows the production of arsenate with time and the greater dissociation of this arsenate as the factor responsible for the characteristic pH change during growth.

Washed cells which had been harvested from a culture showing maximum arsenite oxidizing activity were resuspended in buffer containIng arsenite. These cell suspensions proceeded to oxidize arsenite at a constant rate without lag as shown in Figure 27 and Table XXIX. Demonstration of the stolchiometric conversion of arsenite to arsenate provides evidence that there is no stable arsenylated intermediate in 


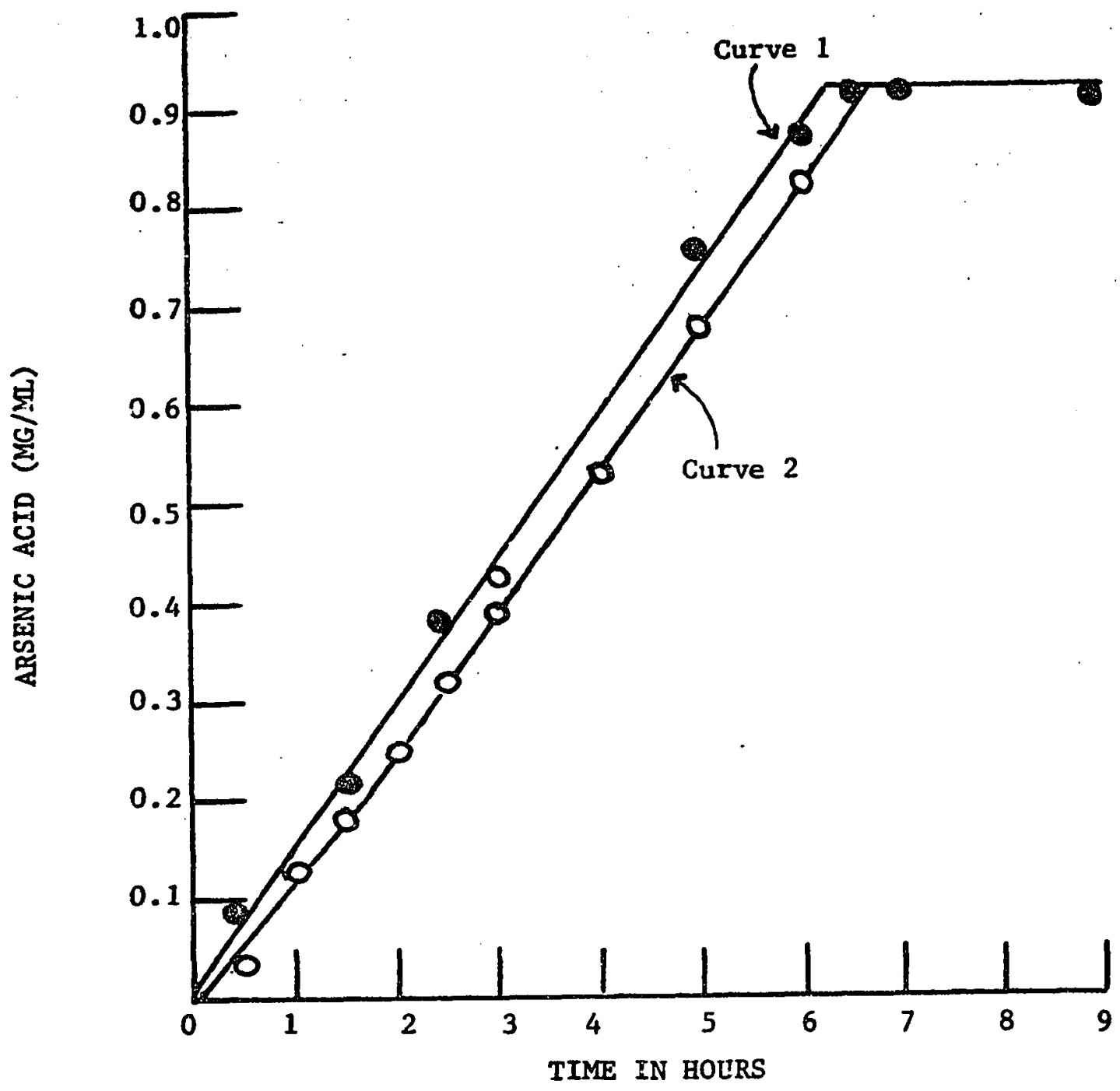

F1gure 26. Plot showing the production of arsenate (and the responsibility of the arsenate for the characteristic $\mathrm{pH}$ changes during growth in an arsenical medium). Ammonium sulfate, magnesium sulfate, and $0.02 \mathrm{M}$ sodium arsenite were added to $0.005 \mathrm{M}$ Tris buffer adjusted to $\mathrm{pH} 7.41$. Growth, arsenite oxidation, arsenate production, and $\mathrm{pH}$ were measured at hourly intervals. Arsenate production $(0-0)$ was estimated by the modifled Fiske and Subbarow procedure. Curve $2(0-0-0)$ was obtained by titrating the same $0.005 \mathrm{M}$ Tris buffer, $\mathrm{pH} 7.41$, with arsentc acid (5 mg/ ml) to the $\mathrm{pH}$ obtained experimentally at hourly intervals. Lines were obtained with the aid of linear regression analysis. 

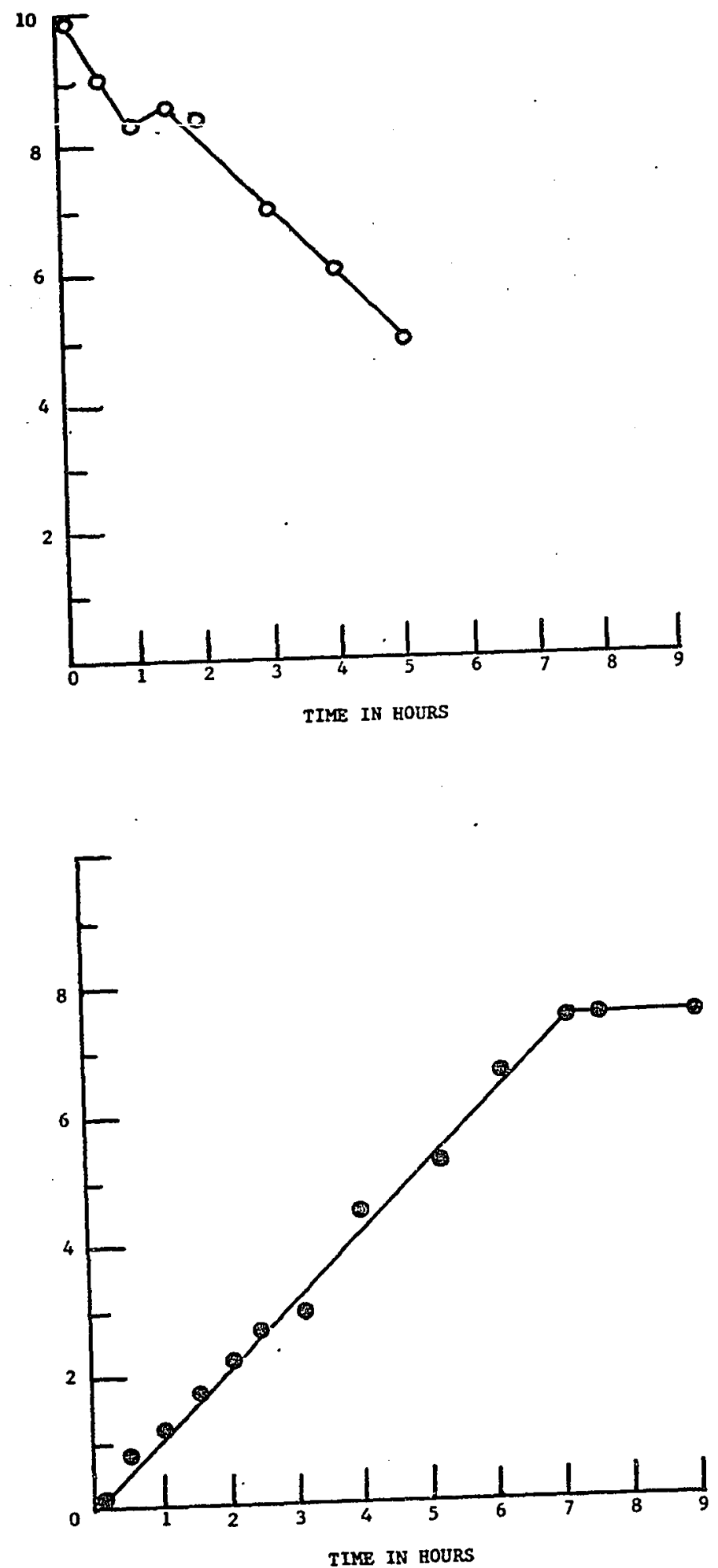

F1gure 27. The disappearance of arsenite (Graph A) and the appearance of arsenate (Graph B) in the enzymatic converslon of arsenite axbenate See fottnote Table XXIX for experimental details. 
TABLE UXIX

ghzYMATIC CONVERSION OF ARSATIT to ARSEAUTB

BY PSEUDOMONAS ACLDOVORANS-ARSEYOXYDANS YBS6

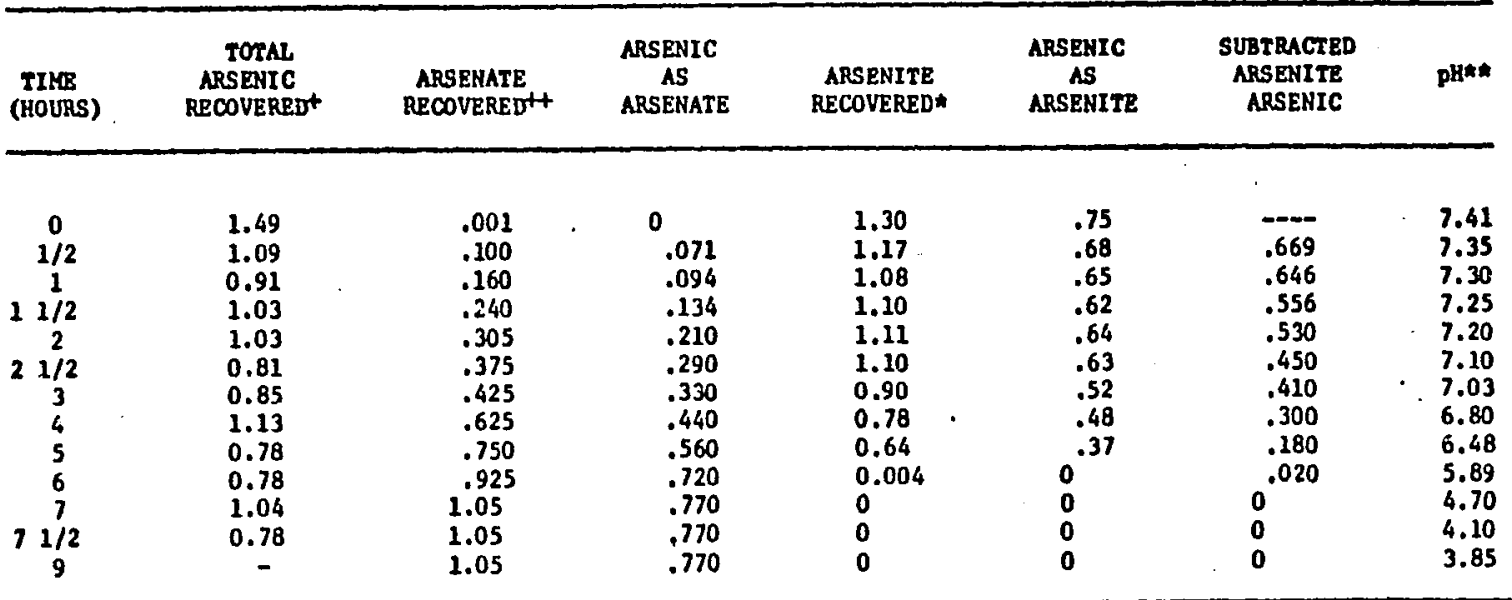

\section{Quentitles expreased in allligrams/ml}

+ Total arsentc determined by OSU Departmat of Agricultural Chenistry using the allver dlethyldithlocarbemate method.

\# Argenate estimated by the modified Fiske and Subbarow colorimetric mathod.

- Arsenite estimaced directly by lodometric titration.

* pH deternined on Coming pH meter with combination electrode.

Two hundred ml of maximally Induced cells were centrifuged under sterile conditione and the supernatant decanted. At zero time the pellet was resuspended in $200 \mathrm{ml}$ of $0.005 \mathrm{Trla}$ buffer, $\mathrm{pH} 7.35$ in a two 11ter erylenmeyer flask. This ausension was lnewbated on a rotary shaker, setting 10 , temperature $32^{\circ} \mathrm{C}$ and at regular Intervale $10 \mathrm{ml}$ allquots were withdrawn from the flask and filtered through an 0.45 micron millipore fliter. No growth occurred during the experiment as determined by turbidity. A constant rate of 3 . wicromoles of arsenite oxidized/hour/mg protein sas determined by the oxygen probe. Boiled cells had no arsenite oxidzing capacity. 
the cell. Figure 28 shows that the stolchiometric conversion of arsenite to arsenate occurred in growing, previously noninduced cells also. It can also be seen from Figure 28 that upon addition of arsenite it immediately disappeared from the medium and was slowly released into the growth medium during exponential growth; the arsenite was totally desorbed at the time arsenate was first detected. This strongly suggests that the uninduced cell envelope has the ability to adsorb arsenite. In order to test binding by cell wall fragments, nonInduced cells grown in nutrient broth were disrupted by repeated freezIng and thawing. When 0.1 gram of disrupted cells per ml was incubated for less than 10 minutes in a solution of $0.05 \mathrm{M}$ Tris, $\mathrm{pH} 7.35$, containIng $0.01 \mathrm{M}$ sodium arsenite at $37^{\circ} \mathrm{C}$, the preparation adsorbed 62 percent of the arsenite as determined fodometrically. A small amount of the bound arsenite could be released by incubation of the sample at $0^{\circ} \mathrm{C}$ for 1 hour in $1 \mathrm{M} \mathrm{NaCl}$ but incubation in $10^{-2} \mathrm{M} \mathrm{NaCl}, 10^{-3} \mathrm{M} \mathrm{MgSO}_{4} \cdot 7 \mathrm{H}_{2} \mathrm{O}$, $0.05 \mathrm{M}$ Tris, $\mathrm{pH} 7.35, \operatorname{CDM}$ without the carbon source, or distilled water showed no release. When the disrupted cells were hydrolyzed with sodium hydroxide, the majority of the arsenite could be recovered as determined by TLC. In contrast to the Tris-suspended cell preparations no arsenite was found to be adsorbed to the same disrupted cell preparation when it was diluted in distilled water, shaken at $360 \mathrm{rpm}$ for 30 minutes at $37^{\circ} \mathrm{C}$, followed by centrifugation for 20 minutes at $0^{\circ} \mathrm{C}$, and the cell pellet then resuspended in $0.05 \mathrm{M}$ Tris. $\mathrm{HCl}$ or phosphate buffers of various $\mathrm{pH}^{\prime} \mathrm{s}$ containing $0.01 \mathrm{M}$ arsenite. Under simflar experimental conditions, noninduced cell preparations of YE56 did not bind arsenite. Neu and Heppel (1965), although admitting that the evidence for the surface 


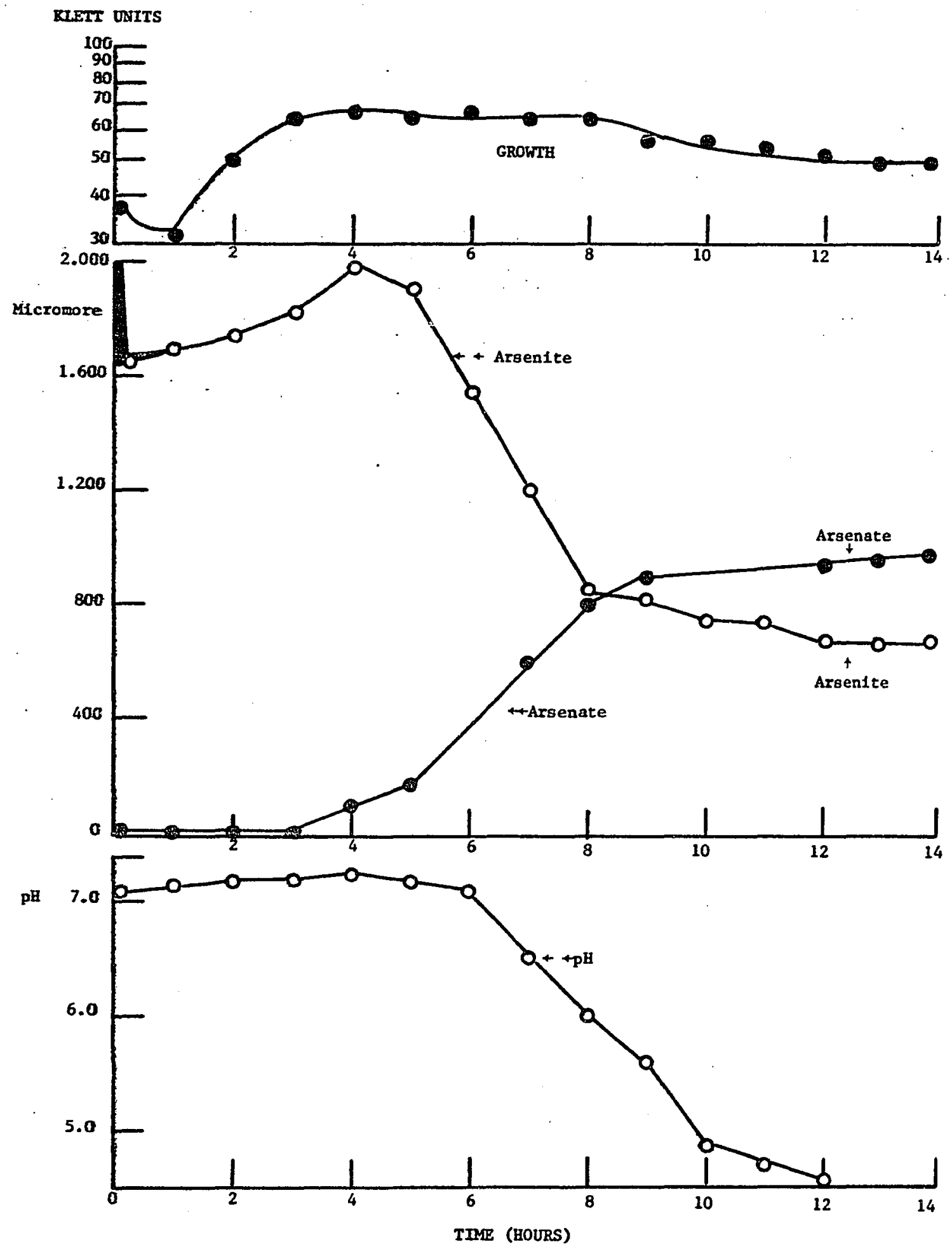

F1gure 28. The enzymatic conversion of arsentte to arsenate by YE56 in growlng, previously nonfinduced cells. At zero time $0.02 \mathrm{M}$ sodium arsent te was added. The top graph shows the growth curve obtained. The bottom graph shows the change of $\mathrm{pH}$ in the ealture during growth. 
location of their enzymes was indirect, did present evidence which showed that enzymes were released by osmotic shock. It could be possible that if such a phenomen of surface binding exists than such a mechanism could be operable in the binding of arsenite to the envelope of YE56. The binding would be very strong because it is not disrupted by high salt concentrations.

Hughes et al., (1970) demonstrated that the concentrations of cations on the wall-membrane were markedly influenced by $\mathrm{pH}$ thus the $\mathrm{pH}$ of the incubation mixture when plotted against enzyme activity was not the actual $\mathrm{pH}$ activity curve of the enzyme under study. Therefore, it seems probable that the effect of $\mathrm{pH}$ on enzyme activity as seen in Figure 12 is really the effect of $\mathrm{pH}$ on the permeability of arsenite. If the arsenite is entering the cell by physical diffusion, the undissociated molecule would be the species entering the cell. Since the pKa of arsentous acid is 9.22 even at $\mathrm{pH}$ values well above the optimum of 6.6 nearly all the arsenite would exist as undissociated molecules. Nevertheless, the activity falls off more above the optimum $\mathrm{pH}$ than can be accounted for by the increased ionization of arsenious acid. The $\mathrm{pH}$ activity curve of cell-free preparations could not be measured since no dye with a constant redox potential over this $\mathrm{pH}$ range could be found. Since it can't be stated with certainty that arsenite oxidizing activity in whole cells is due to the enzyme system alone, it seems possible that the activation energy of $16.2 \mathrm{kcal} / \mathrm{mole}$ represents permeability characteristics of the cell.

As shown In Figure 29 the rate of oxidation by whole cells was a linear function of the cell concentration. An approximate $k_{m}$ of $4.5 \mathrm{x}$ 
10-4 M, was obtained with whole cells as shown in Figure 30 . Using the Thunberg method previously described in Materials and Methods, a sonicated cell extract revealed a $\mathrm{K}_{\mathrm{m}}$ of approximately $2 \times 10^{-6} \mathrm{M}$ or about 2 orders of magnitude lower than that of whole ceils. As shown in Figure 30 , concentrations of arsenite greater than $8 \times 10^{-3} \mathrm{M}$ showed substrate inhibition. With whole cells, the overall rate of arsenite oxddation seems to be limited by the rate of entry of arsente into the cell. This entry appears to give neither a simple diffusion or saturation curve making it exceedingly difficult to obtain an approximate $R_{m}$.

The main thrust of Turner's work (1949) was study of the "arsenite dehydrogenase" and its associated cytochromes. Work in this laboratory wing the sequential addition of inhibitors and substrates as outlined by Heinen (1971) confirmed Turner's conclusions that the electrons from arsenite were transferred through a cytochrome system. One difference was noted however as follows: Turner found that incubation of whole cells with $10^{-3} \mathrm{M}$ potassium cyanide for 30 minutes produced complete inhibition of respiration; however, after the same incubation period, the respiration of whole cells of YE56 was inhibited only 53 percent. AlternatIve explanations for this finding are that YE56 may be impermeable to $\mathrm{KCN}$, that more than one pathway for electron transport is present in this organism or perhaps YE56 includes at least one terminal oxidase which is insensitive to KCN as has been shown by Arima and Oka (1965). An Interesting phenomenom observed consistently is the ability of YE56 to reoxtdize reảuced 2,6 dichlorophenolindophenol in the presence of oxygen as shown in Figure 11 . 


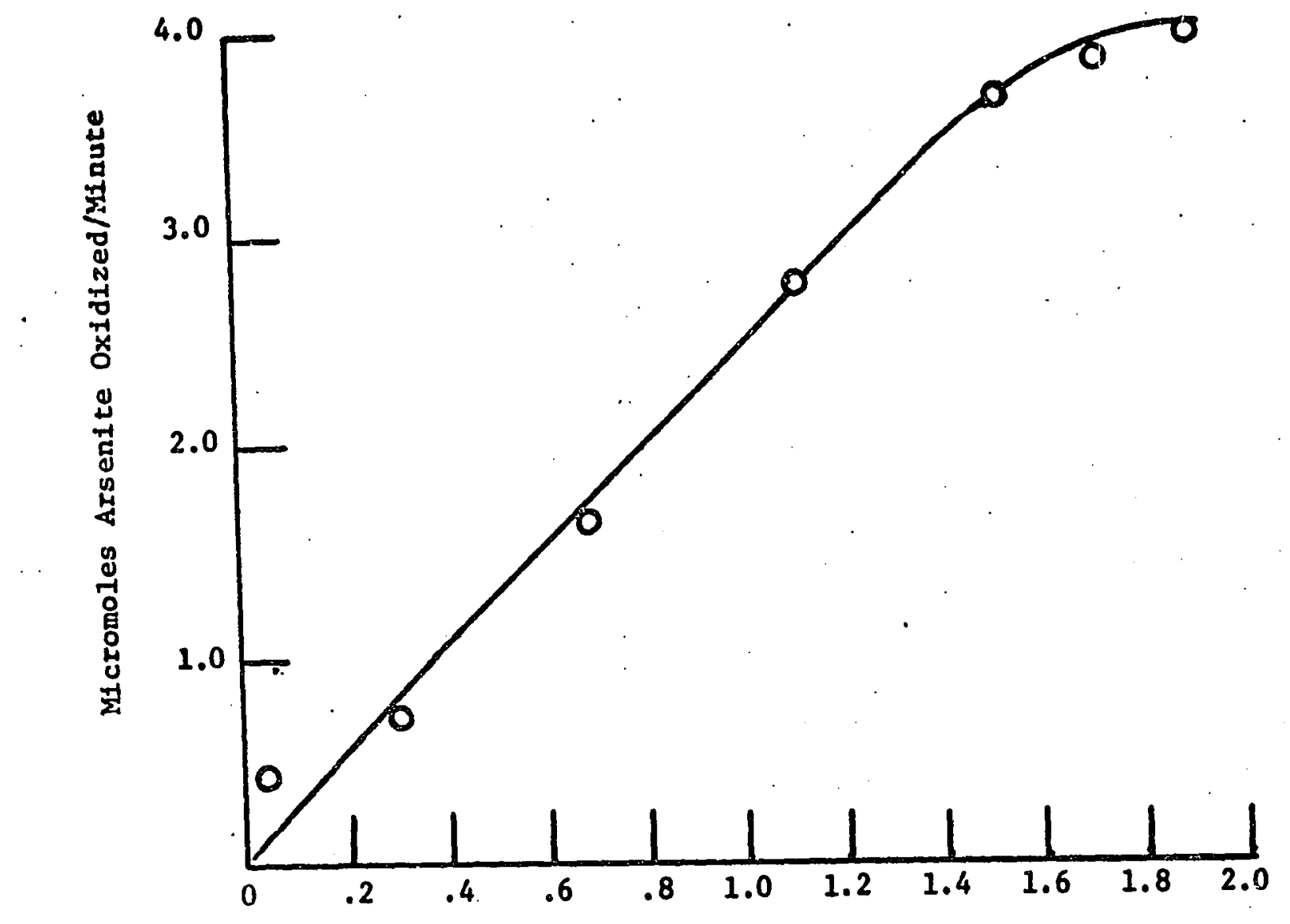

Figure 29. The rate of arsenite oxidation by a washed suspension of maximally induced whole cells of Pseudomonas actdovoransarsenoxydans YE56. Cells were prepared and arsenite oxideion was estimated as described in Materials and Methods. Uninduced cells were used as control. 


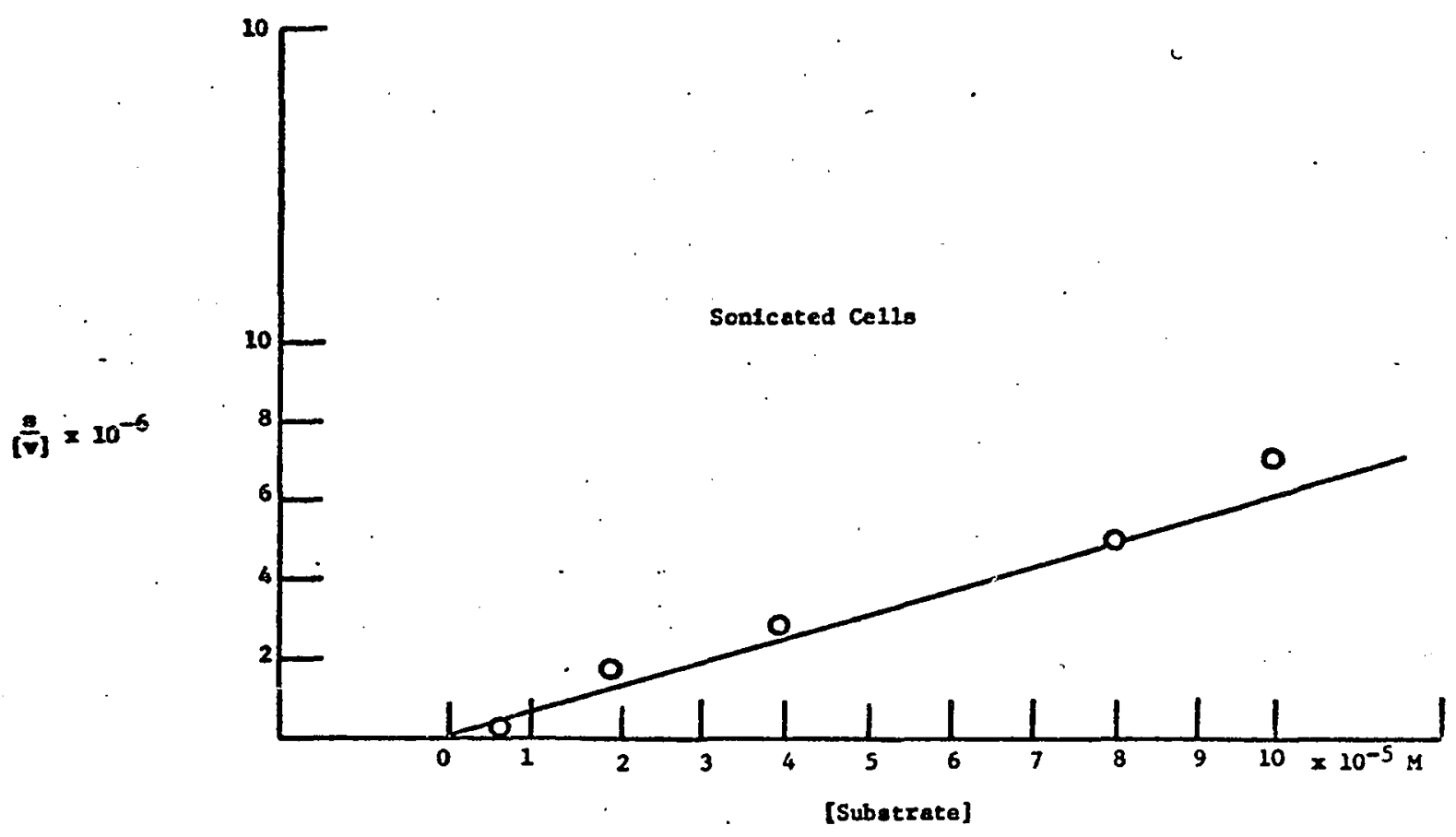

$\left[\frac{\sin }{[v} \times 10^{-6}\right.$

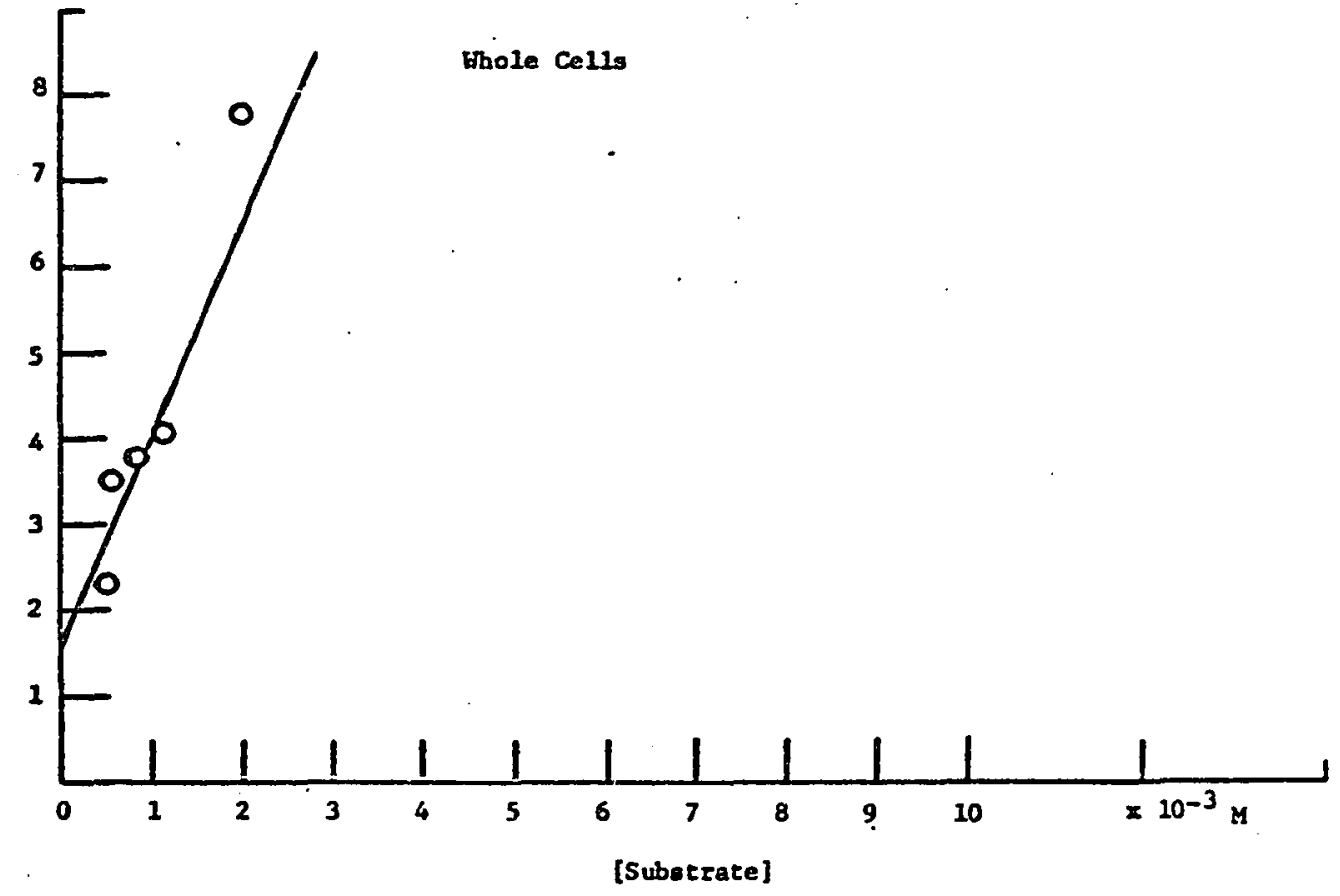

P1gure 30. The effect of ersentte concentration of velocity of arsenite oxidation. 

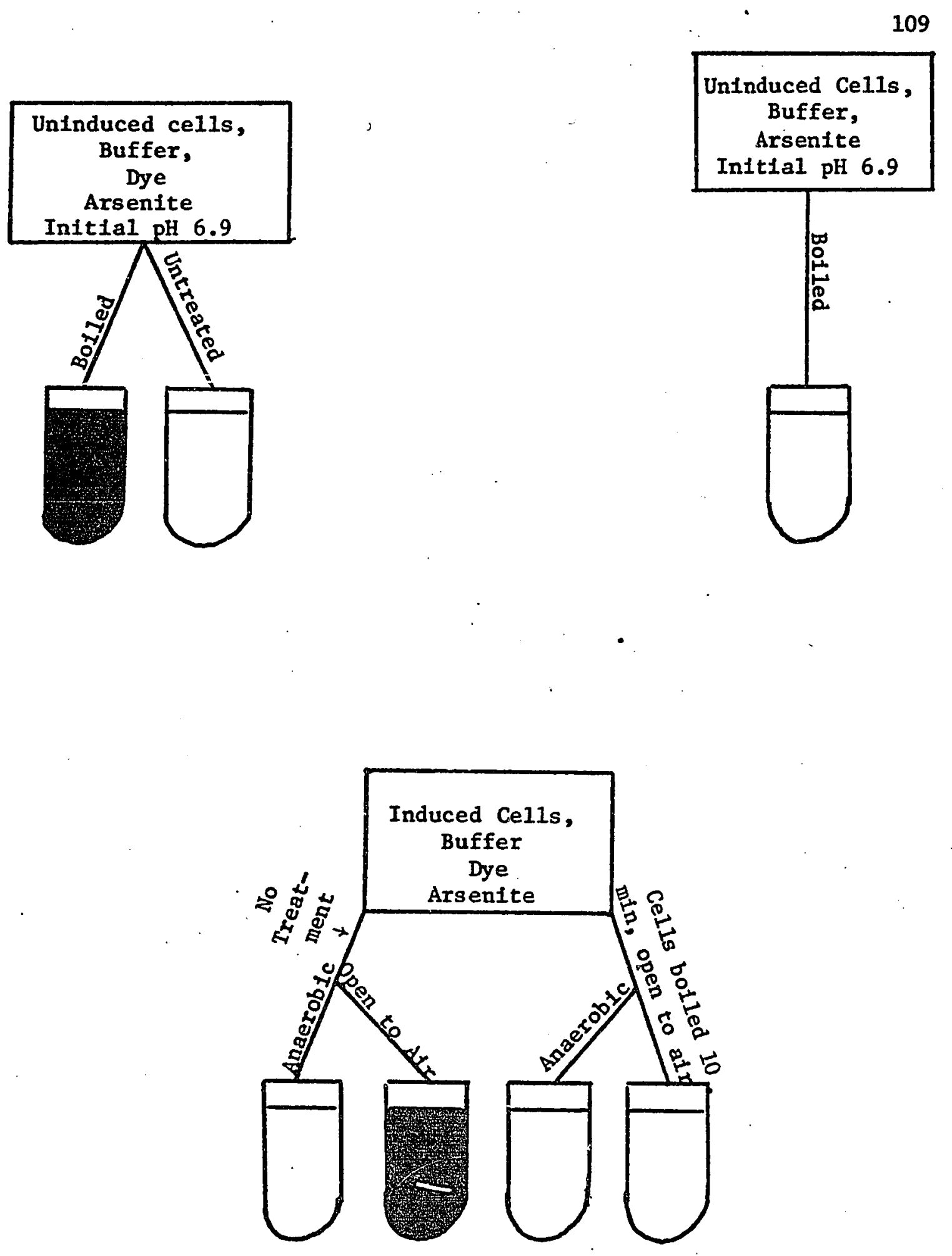

Figure 31. Diagram showling that a culture of Pseudomonas acidovoransarsenoxydans YE56 maximally induced to oxidize arsenite possesses a cytochrome that can oxidize reduced $2,6 \mathrm{dich}-$ lorophenol indolphenol. See legen Figure 22 for details except that whole cells which had been frozen overnight and thawed prior to the experiment were used exclustvely. 
An example of an organism which is capable of obtaining energy from the oxidation of inorganic compounds is Thiobacillus novellus which can oxidize inorganic sulfur to sulfuric acid; in contrast, as shown in Figure 32, Pseudomonas acidovorans-arsenoxydans YE56 does not use the energy of arsenite oxidation to increase growth rate or the final cell yield. They also were not able to obtain energy from the oxidation of sulfite to sulfate, and either were unable to oxidize nitrite or did so only slowly. Monod (1949) showed that the amount of microbial growth with a limiting amount of energy source is proportional to the amount of energy source added, 1.e. $G=K C$, where $G$ is the amount of growth, $\mathrm{C}$ is the energy source, and $\mathrm{K}$ is a constant. Many observations have proven that the value of $K$ for a given substrate can be reproducibly determined and has a fixed value for each substrate. Bauchop and Elsden (1962) suggested that the growth be expressed as micrograms per $\mathrm{ml}$ and substrate concentration as micromoles per $\mathrm{ml}$. $\mathrm{K}$ then becomes the molar yield coefficient $\left(\mathrm{Y}_{\text {sub }}\right)$; and growth on substrates with different molecular weights can be compared. In addition they proposed that the growth yield of an organism was proportional to the amount of ATP produced by its catabolic process. Thus, they defined $\mathrm{Y}_{\mathrm{ATP}}$ as the grams dry weight of cells produced per mole of ATP synthesized as determined experimentally. Under anaerobic conditions on complete media with the energy source as the limiting factor, they found this $\mathrm{Y}_{\text {ATP }}$ value to be a constant (about 10.5 grams of cells per mole of ATP). During aerobic growth, however, part of the carbon source is converted Into cellular material and part oxidized to produce energy. The proportion assimilated can be determined fairly accurately from the amount 


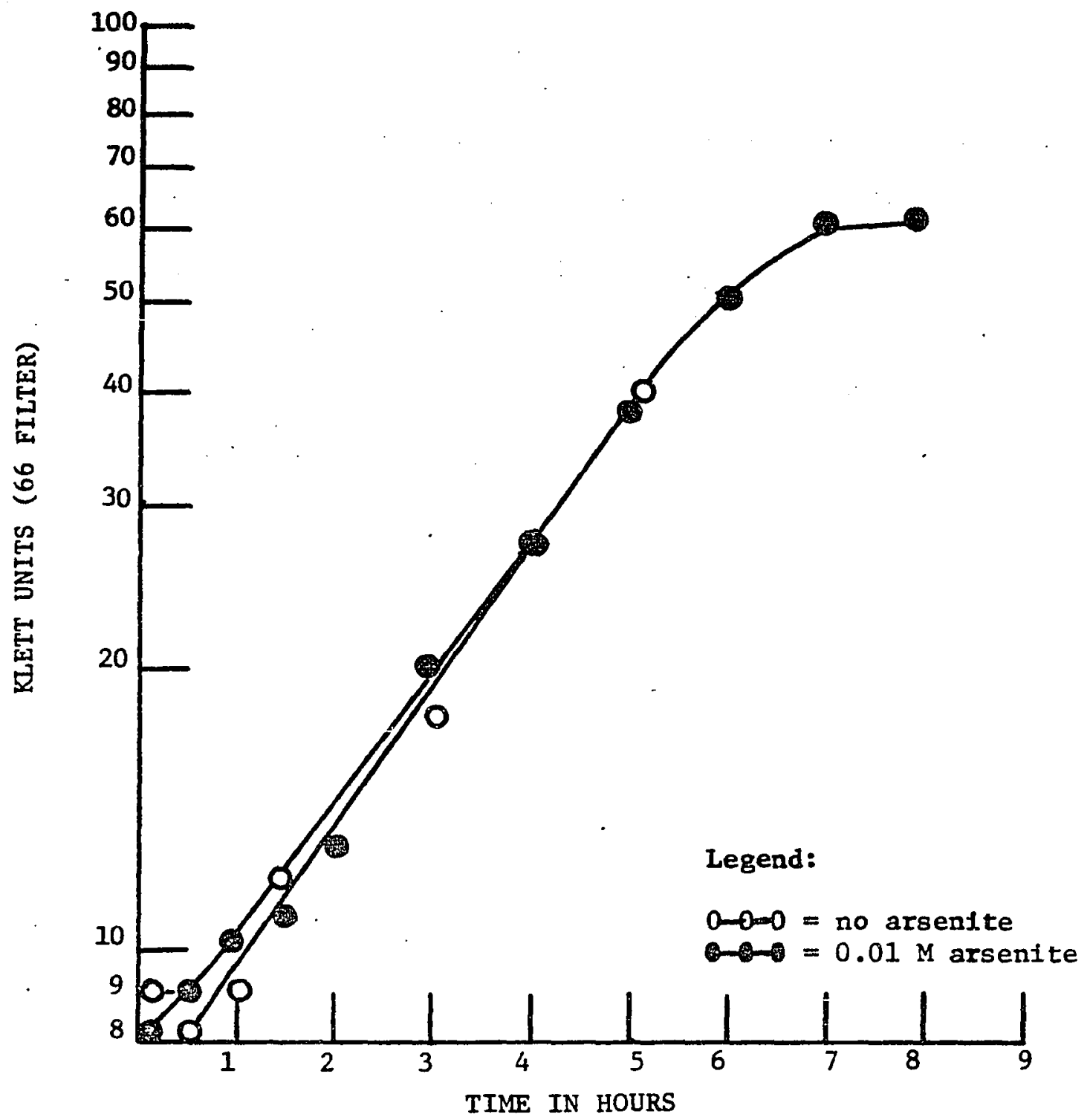

F1gure 32. Effect of $0.01 \mathrm{M}$ arsenite on the growth rate. The cu1tures vere grown at $37^{\circ} \mathrm{C}$ in a shaking incubator at 350 rpm in Klett flasks filled to 20 percent of capacity. The chemically defined medium contained in addition to the vitanin supplement and casamino acids (50 micrograms/ mi) $100 \mathrm{micrograms} / \mathrm{ml}$ aspartic acid. The carbon and energy source was glutamate ( 2 millimolar) and the initial $\mathrm{pH}$ was adjust to 6.8 
of dry weight and the amount of carbon in cells. Attempts to determine aerobic $\mathrm{Y}_{\text {ATP }}$ growth yields in the same way as for fermentations have led to the suggestion that the efficiency of oxidative phosphorylation In microorganisms is Iow (Hernandez and Johnson, 1967) or that the efficiency of generating ATP is high but coupling between anabolism and catabolism is low.

Therefore, it seems that "molar production of ATP in aerobic cultures may only be estimated and not determined", (Payne, 1970). "An approach giving results...more directly comparable would be the correlation with avallable electrons in the substrate", (Forrest, 1969). Mayberry et al., (1967) found for heterotrophic and auxotrophic growth that grams dry weight per available electrons from the substrate $\left(Y_{a v} e^{-)}\right.$will approximate $3.14 \pm 0.11$ irrespective of the substrate or organism used, provided that the organtṣm completely consumed the substrate, that cells and carbon dioxide vere the only significant products and that ammonium salts rather than nitrate was used as the source of nitrogen.

Cell yields from the aerobic growth of Pseudomonas acidovoransarsenoxydans $\mathrm{YE} 56$ in $\mathrm{CDM}$ medium and their $\mathrm{Y}_{\mathrm{av}} \mathrm{e}^{-}$Table XXX are in good agreement with those reported in the literature, Table XXXI. The determination of dry weight at its maximum value seemed to be the most critical point in the determination; therefore, growth as estimated by turbidity was followed to its maximum value (at the beginning of stationary phase) where dry weight was determined.

Strain YE56 can use glycero1, lactate, pyruvate, acetate, and al1 the Krebs cycle intermediates as a source of cell material and energy. 
TABLE $2 X X$

GELC YIELDS FROM THE AEROBIC GROWTH OF PSEUDOMONAS ACIDOVORANS-ARSENOXYDANS ON CHEMICALLY DEFINED MEDIA

\begin{tabular}{|c|c|c|c|c|}
\hline $\begin{array}{l}\text { Exp. } \\
\text { No. }\end{array}$ & SUBSTRATE & $Y_{\text {sub }}$ & $\begin{array}{l}\text { av } e^{-} \\
x o l e^{-1}\end{array}$ & $Y_{\text {av }} e^{-}$ \\
\hline 1. & $\begin{array}{l}\text { Acetate } \\
\text { Citrate } \\
\text { Succinate } \\
\text { a-ketoglutarate } \\
\text { Glutamate }\end{array}$ & $\begin{array}{l}25.6 \\
64.0 \\
42.7 \\
43.6 \\
53.3\end{array}$ & $\begin{array}{r}8 \\
18 \\
14 \\
16 \\
18\end{array}$ & $\begin{array}{l}3.25 \\
3.56 \\
3.05 \\
2.72 \\
2.96\end{array}$ \\
\hline 2 & $\begin{array}{l}\text { Acetate } \\
\text { Acetate }+0.01 \mathrm{M} \text { arsenite } \\
\mathrm{P} \text { - urate } \\
\text { Pyruvate }+0.01 \mathrm{M} \text { arsenite } \\
\text { Citrate } \\
\text { Citrate }+0.01 \mathrm{M} \text { arsenite } \\
\text { a-ketoglutarate } \\
\alpha \text {-ketoglutarate }+0.01 \mathrm{M} \text { arsenite } \\
\text { Glutamate } \\
\text { Glutamate }+0.01 \mathrm{M} \text { arsenite } \\
\text { Succinate } \\
\text { Succinate }+0.01 \mathrm{M} \text { arsenite }\end{array}$ & $\begin{array}{r}23.9 \\
6.4 \\
36.8 \\
36.8 \\
64.0 \\
64.0 \\
51.7 \\
51.7 \\
51.7 \\
51.7 \\
38.7 \\
38.7\end{array}$ & $\begin{array}{r}8 \\
8 \\
10 \\
10 \\
18 \\
18 \\
16 \\
16 \\
18 \\
18 \\
14 \\
14\end{array}$ & $\begin{array}{l}3.00 \\
0.81 \\
3.68 \\
3.68 \\
3.56 \\
3.56 \\
3.23 \\
3.23 \\
2.87 \\
2.87 \\
2.76 \\
2.76\end{array}$ \\
\hline 3 & $\begin{array}{l}\text { Glycerol } \\
\text { Glycerol }+0.01 \mathrm{M} \text { arsenite } \\
\text { Citrate } \\
\text { Citrate }+0.01 \mathrm{M} \text { arsenite } \\
\text { a-ketoglutarate } \\
\text { a-ketoglutarate }+0.01 \mathrm{M} \text { arsenite } \\
\text { Succinate } \\
\text { Succinate }+0.01 \mathrm{M} \text { arsenite } \\
\text { Oxaloacetate } \\
\text { Oxaloacetate }+0.01 \mathrm{M} \text { arsenite } \\
\text { Pyruvate } \\
\text { Pyruate }+0.01 \mathrm{M} \text { arsenite }\end{array}$ & $\begin{array}{l}44.3 \\
10.5 \\
54.5 \\
54.5 \\
42.3 \\
42.3 \\
39.8 \\
39.8 \\
35.2 \\
12.4 \\
26.1 \\
26.1\end{array}$ & $\begin{array}{l}14 \\
14 \\
18 \\
18 \\
16 \\
16 \\
14 \\
14 \\
10 \\
10 \\
10 \\
10\end{array}$ & $\begin{array}{l}3.16 \\
0.75 \\
3.03 \\
3.03 \\
2.66 \\
2.66 \\
2.84 \\
2.84 \\
3.52 \\
1.24 \\
2.61 \\
2.61\end{array}$ \\
\hline
\end{tabular}

$Y_{\text {sub }}=\frac{\text { grams }}{\text { moles }}$ 
TABLE XXXI**

CELL YIELDS FROM AEROBIC GROWTH OF HETEROTROPHS

\begin{tabular}{|c|c|c|c|c|c|c|c|c|c|c|c|c|c|c|c|}
\hline $\begin{array}{c}\text { Organ- } \\
\text { ism }\end{array}$ & $\begin{array}{l}\text { Rel- } \\
\text { erence }\end{array}$ & Medium & Substrate & $\begin{array}{c}Y_{\text {eus }} \\
(s X X \\
\left.\text { mole }{ }^{-4}\right)\end{array}$ & $\begin{array}{l}\text { ave } e^{-X} \\
\text { mole } e^{-1}\end{array}$ & 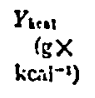 & $\underset{\left.\left[a e^{-}\right)^{-1}\right]}{\left.Y_{a}\right]}$ & $\begin{array}{l}\left(n_{1}, \ldots, n\right) \\
\therefore, n .\end{array}$ & $\begin{array}{l}\text { Rei. } \\
\text { erenix }\end{array}$ & Maliun & Sulhsirnte & $\begin{array}{c}Y_{\text {atb }} \\
(s X \\
\text { molc-1) }\end{array}$ & $\begin{array}{l}\text { ove } X \\
\text { mole-1 }\end{array}$ & 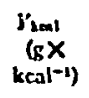 & $\underset{\left.\left(a v e^{-}\right)^{-1}\right)}{Y_{a w-}}$ \\
\hline \multirow{25}{*}{$\begin{array}{l}\text { Aerobacter } \\
\text { esrogeses }\end{array}$} & $50 ?$ & Minimal & Maltose & 149.2 & 48 & $0.1+1$ & 3.11 & lideribens & 33 & Mlinimal & durtite & 20.4 & 8 & - & 2.55 \\
\hline & & & $\begin{array}{l}\text { Sucrose } \\
\text { Mannitol }\end{array}$ & $\begin{array}{r}172.7 \\
95.5\end{array}$ & $\begin{array}{l}48 \\
26\end{array}$ & 0.144 & $\begin{array}{l}3.60 \\
3.67\end{array}$ & inturs & 114 & Minimal & Laviste & 27.8 & 12 & - & 2.32 \\
\hline & & & Sorbitol & 97.4 & 26 & 0.135 & 3.75 & Truros. & 137 & Mininal & Sucrose & 115.0 & 48 & - & 2.40 \\
\hline & & & Galactose & 73.5 & 24 & - & 3.06 & poru cros & isso & & & & & & \\
\hline & & & Clucose & 72.7 & 24 & $0.1+3$ & 3.03 & iriudo & 84 & Minimal & Binkute & 86.8 & 30 & 0.105 & 2.89 \\
\hline & & & Mannose & 69.4 & 24 & - & 2.89 & $m \cdot u_{u}$ ss $C_{1}$ & $C_{11 B} B$ & & l'benylylyox- & 102.2 & 32 & 0.105 & 3.20 \\
\hline & & & Fructose & 76.1 & 24 & 0.139 & 3.17 & & & & ylute & & & & \\
\hline & & & Gluconate & 62.2 & 22 & 0.138 & 2.83 & & & & blowgitutinte & 111.0 & 36 & 0.113 & 3.108 \\
\hline & & & Galactonate & 66.3 & 22 & 0.136 & $3.01=$ & & & & Succill.,"n & 42.3 & 14 & 0.113 & 3.02 \\
\hline & & & Ribitol & 61.8 & 22 & - & 2.81 & & & & Arctate & 23.5 & 8 & 0.1997 & 2.94 \\
\hline & & & L-Arabinose & 65.3 & 20 & 0.132 & 3.27 & & & & Succinulet & 72.2 & 22 & 0.111 & 3.28 \\
\hline & & & Ribose & 53.2 & 20 & - & 2.66 & & & & acctate & & & & \\
\hline & & & Xylose & 52.2 & 20 & - & 2.61 & & & & Dodccanol & 217.0 & 72 & 0.112 & 3.01 \\
\hline & & & Glucuronate & 55.3 & 20 & 0.130 & 2.77 & Pecudo. & 78 & Minimal & Glucose $\left(30^{\circ}\right)$ & 78.1 & 24 & 0.116 & 3.25 \\
\hline & & & Galacturonate & 55.6 & 20 & 0.135 & 2.78 & monos oe & Berm. & & Glucose $\left(37^{\circ}\right)$ & 76.2 & 24 & 0.114 & 3.18 \\
\hline & & & Citrate & 61.8 & 18 & - & 3.43 & sinosa & & & Gluconate $\left(30^{\circ}\right.$ & 75.5 & 22 & 0.119 & 3.43 \\
\hline & & & Rhamnose & 49.0 & 26 & 0.125 & - & & & - & Glucounte (37") & 73.1 & 22 & 0.120 & 3.32 \\
\hline & & & Glycerol & 41.8 & 14 & - & 2.99 & & & & 2.0xosluco- & 64.6 & 20 & 0.121 & 3.23 \\
\hline & & & Dihydroxy- & 31.9 & 12 & - & 266 & & & & nate $\left(30^{\circ}\right)$ & & & & \\
\hline & & & acetone & & & & & & & & 2.0xugluce- & 62.0 & 20 & 0.118 & 3.10 \\
\hline & & & Alyo-Inositol & 52.2 & 24 & 0.131 & - & & & & suate (37") & & & & \\
\hline & 51 & Mlinimal & Glucose & 72.7 & 24 & 0.143 & 3.03 & & 81 & Minimal & Glucose & 70.4 & 24 & - & 2.93 \\
\hline & 55 & Mininaal & Glycerol & 45.0 & 14 & - & 3.21 & & & & Gluesunte & 62.0 & 22. & - & 2.82 \\
\hline & 133 & Mininıl & Glycerol & 50.0 & 14 & - & 3.57 & & & & Citrale & 57.5 & 18 & - & 3.19 \\
\hline & 103 & Minimal & Citrate & 19.6 & 18 & - & 1.09 & & & & a.0xnglutarate & 52.0 & 16 & - & 3.25 \\
\hline \multirow{2}{*}{$\begin{array}{l}\text { Aerobacier } \\
\text { clmsras }\end{array}$} & 108 & Minimal & Glucose & 79.2 & 24 & $=$ & 3.30 & & & & Suecinate & 41.6 & 14 & - & 2.97 \\
\hline & 56 & Minimal & Glycerol & 48.2 & 14 & - & 3.44 & & & & Fomburate & 33.0 & 12 & - & 3.17 \\
\hline \multirow{2}{*}{$\begin{array}{l}\text { Arthrobal- } \\
\text { ter g!nbif }\end{array}$} & & Minimal & Glucose & 94 & 2.4 & - & 3.92 & & & & Malate & 38.5 & 12 & - & 3.21 \\
\hline & iformis & s & & & & 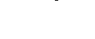 & & & & & Pyrusite & 30.0 & 10 & - & 3.00 \\
\hline \multirow{3}{*}{$\begin{array}{l}\text { Arnenbse- } \\
\text { ter chroo }\end{array}$} & 30 & Minimal & Mannitol & 63.5 & 26 & - & 2.44 & & & & Arcinte & 17 & 3 & - & 2.15 \\
\hline & ocoecum & & & & & & & & 66 & Mlinimal & Malate & 44.1 & 12 & - & 3.68 \\
\hline & & & Glucose & 81.3 (av) & v) 24 & & 3.39 & & 113 & Mtinimal & Glucose & 48 & 24 & - & 2.00 \\
\hline $\begin{array}{l}\text { Bucillus } \\
\text { subbitis }\end{array}$ & 2 & mented & & & & & & lscindo. & 5s & Minimal & Gluense & 09.5 & 24 & 0.111 & 2.90 \\
\hline \multirow{2}{*}{$\begin{array}{l}\text { Bacter- } \\
\text { ium H }\end{array}$} & $1+3$ & Minimal & Glucose & 72 & 24 & 0.105 & 3.00 & monas & & & Ethanol & 22.1 & 12 & 0.075 & - \\
\hline & R & & & & & & & fincressen & & & Acctatc & 16.8 & 8 & 0.080 & - \\
\hline \multirow{5}{*}{$\begin{array}{c}\text { Candida } \\
\text { wlitis }\end{array}$} & 58 & Minimal & Glucose & 91.9 & 24 & 0.128 & 3.83 & & & & Lactate & 28.8 & 12 & 0.111 & 2.40 \\
\hline & & & Acetate & 21.6 & 8 & 0.100 & 2.70 & & & & Malate & 34.8 & 12. & 0.112 & 2.90 \\
\hline & & & Ethanol & 31.6 & 12 & 0.094 & 2.63 & & 106 & Alinimal & Glucose & 119.1 & 24 & - & 4.96 \\
\hline & 14 & Mininal & Glucose & $90.7(a v)$ & v) 24 & - & 3.78 & Rhicobium & 61 & Mininial & Sucrose & 144.0 & 48 & - & 3.00 \\
\hline & 15 & Mlinimal & Glucose & 92.7(av) & v) 24 & - & 3,86 & & & & & & & & \\
\hline \multirow{3}{*}{$\begin{array}{l}\text { Esthas: } \\
\text { richin } \\
\text { coli }\end{array}$} & 117 & Atinimal & Glucose & 67.8 & 24 & - & 2.83 & Socchuro- & 83 & Supple. & Glucose & 71.3 & 24 & - & 2.97 \\
\hline & 113 & Minimal & Glucose & 94.0 & 24 & - & 3.92 & myces & & mented & & & & & \\
\hline & 100 & Minimal & Glucose & 90.0 & $\cdot 24$ & - & 3.73 & cerstisicen & & Supples & Glucose & 78.4 & 28 & - & 3.27 \\
\hline
\end{tabular}

** Payne et al. 1967 
Previously, arsenicals have been used to determine the presence of "sluggish" sulfhydryl groups in enzymes 1.e., the kind not easily oxidized by atmospheric oxygen. 'Barron (1951) described two kinds of these sulfhydryl containing enzymes. The first group of enzymes act as electron mediators between substrate and coenzyme (enzymes in this group Include pyruvate oxidase, alpha-ketoglutarate oxidase). Trivalent organic arsenicals combine reversibly with the sulfhydryl groups of these enzymes and dissociate readily on Increase of the $\mathrm{pH}$. For strain YE56 the $Y_{a v} e^{-}$for pyruvate and citrate are unchanged in the presence of $0.01 \mathrm{M}$ arsenite indicating that unless the organism has evolved enzyme systems resistant to arsenite some mechanism must be operating to protect these labile sulfhydryl groups. Although Sanadi et al. (1958) demonstrated that arsenite Inhibited lipoic acid dependent enzymes, Grunert and Rohdenburg (1960) and Peters et al. (1946) showed that sodium arsenite is not as toxic to alpha-keto acid oxidations as the organic arsenicals, especially lewisite.

The second kind of sulfhydryl containing enzymes are enzymes which use sulfhydryl groups to transfer phosphate from ATP. (Enzymes In this group include hexokinase, acetate kinase, and glycerol kinase.) In this group, the sulfhydryl containing enzyme is postulated to act as a bridge between the ATP and substrate with the union of the protein to the substrate taking place through the sulfhydryl groups. This could explain the low values obtained for strain YE56 for acetate and glycerol in the presence of arsenite as shown in Table XXX. The low value for oxaloacetate in the presence of arsenite is unexplainable since YE56 contains all the Kreb cycle enzymes as demonstrated by the 
oxygen probe method and even if oxaloacetate were converted back to pyruvate there is no reduction in $\mathrm{Y}_{\text {av }} \mathrm{e}^{- \text {for this compound. }}$ 


\section{DISCUSSION}

Pseudomonads possess several tratts which allow them to occur in large numbers wherever organic matter is found and, consequently, has earned them the name, "nature's scavengers".

1. Alexander (1970) considers their ability to grow rapidly the probable reason for their quick colonization in many ecosystems; however additional traits may over-ride the benefits of their potential for rapid growth.

2. Their nutritional requirements are simple.

3. Their wide metabolic versatility has been well documented by Stanter et al. (1966). A single Pseudomonad can be capable of using as many as 100 different organic compounds as sole sources of carbon and ergy. In addition to the organic compounds commonly used by most aerobic bacteria (simple carbohydrates, amino acids, organic acids), members of this group can attack such substances as camphor, testosterone, naphthalene and ethylenediaminetetracetic acid.

4. Some species can store poly-beta-hydroxybutyric acid as an endogenous reserve.

5. Some species produce melanin-like plgments which protect them from digestion by the extracelilular enzymes (glucamase and chitinase) of microital predators (Bu11, 1970)。

6. Their high mean guanine plus cytosine content ( 63 percent) appears to protect them from ultraviolet inactivation (Singer and Ames, 1970); some species possess cartenoid or melanin-like pigments which definitely shield them against solar radiation (Seiji and Iwashita, 
1964).

7. Spontaneous mutant cells arise at a frequency of $10^{-8}$ mutations/cell generation. These mutations generally are stable and often occur as deletion mutants (Ornston et al., 1969). In addition pseudomonads contain autotransferable factors. The camphor, octane, and sallcylate degradative pathways of Pseudomonas have recently been. shown to be specified by genes carrled on plasmids which are broadly transmissible from one species to another (Chakrabarty, 1972). In the same paper, Chakrabarty discusses finding a drug resistance factor which was transmissible from Pseudomonas to $\underline{\mathrm{E}}$. $\underline{\text { coli }}$ and was capable of co-existance with several of the degradative pathway plasmids. In the current study strain YE56 was found to be resistant to chloramphenicol, aureomycin and terramycin. In spite of the fact that Pseudomonas is frequently Iysogenic (Holloway, 1969), no evidence of bacteriophage parasitism was found with repeated attempts to induce a 1ysogenic phage from YE56.

In liquid enrichment cultures with soil as inoculum, pseudomonads are the commonest organism isolated with a wide range of carbon sources (Gibson, 1957). However, a series of soil perfusion apparatuses set up at room temperature with adequate aeration containing 30 grams each of sol1 and sand, 6.5 grams of an organic or inorganic arsenical, 0.84 grams sodium bicarbonate, and $500 \mathrm{ml}$ water (final $\mathrm{pH} 8.0$ ) were operated for two weeks. No oxidation or reduction of any of the arsenicals was found. (In one apparatus soil to which arsenic trioxide had been applied in 1961 was used.) However, wher 1000 micrograms per ml sodium arsenite were added to raw sewage under the same conditions, arsenite 
disappearance was detected in less than one week. Subsequent work indicales that the failure to isolate arsenite oxidizers from the soil may hilve been due to the lack of an added carbon source; however, no organism (ranging from fungi through yeasts and bacteria) selected from M. Alexander's private collection for their unusual degradative abilitles, had the capacity to convert arsenite, arsenate, monomethane arsonic acid or dimethyl arsenic acid.

Although pseudomonads are commonly isolated from soil and water Stanier et al., 1966), Winogradsky and others have shown that pseudrmonads are rarely seen in soll from fallow land (Gibson, 1957). Gibson (1957) found that as soon as soil was contaminated with soluble organic material, a different microflora superimposed itself, consisting of spore-formers and fluorescent pseudomonads. Thus, a single viable cell may have traits that are of such selective value that they increase until they assum a dominant position and once they exhaust the substrate, they die out. Ueda and Earle (1972) found that Pseudomonas sp., common to water and soil, were equal to half of all the strains of bacteria isolated from activated sludge. This confirms the earlier findings of Anderson and McCoy (1963) that the flora of sewage sludge was dominated by pseudomonads. Therefore, it would appear that in nature organisms capable of arsentte oxidation are selected through conditions existing in the environment, i.e. for the work desc ibed here, sewage. An interesting sidelight is the observation that a medical textbook: currentiy in use (Sollman, 1953) makes the following statement, "the acquired tolerance to ingested arsenite is due to its decreased adsorption from the gut". In view of the fact that pseudomonads are 
part of the intestinal community, it is interesting to speculate that the acquired tolerance to ingested arsentte could be due to the enrichment for an arsenite oxidizing population of pseudomonads in the intestine. Here they would convert toxic arsenite to arsenate which is tolerated in higher concentrations and which is rapidly excreted by the human body.

In this research, organisms occurring in sewage sludge of a commercial plant were found to resemble Green's Bacillus arsenozydans, now 1ost, and Turner's Achromobacter arsenoxydans-tres. Green 1solated the Baclilus from an arsenical cattle dip while Turner's were found as contaminants carried into arsenite disinfectañis by cattle. Turner could not determine whether the organisms came from soil, water or feces. In addition to similar isolation habitats, the biochemical and nutritional resemblance between the organisms of Green, Turner and Pseudomonas acidovorans-arsenoxydans was striking, although morphologically all three isolates differed. Both Turner and Green found it difficult to determine the location of flagella on the cell but stated they thought It to be peritrichous. There was no electron microscope in those days but in the intervening time Stanier et al., (1966) has shown the appearance of lateral flagella of shorter length, which definitely are not pili, in two strains of $\underline{P}$. acidovorans when they were grown at low temperature. Thus, it may be that Green's Bactllus, Turner's Achromobacter and Pseudomonas acidovorans-arsenoxydans strain YE56-represent populations of an identical species that differ because of their unique adjustment to particular conditions in an environment and, therefore, Instead of being different species merely represent ecotypes of the same 
species. This is again a reflection of the environmeat, in the case used for this research, sewage, which merely selected for the varlant most suited to the locale.

The most important difference found using YE56 and Turner's description of Achromobacter was induction of arsenite oxidation. With Tuxner's organism enzymic activity appeared during early growth in chemlcally defined arsenite medium; while activity in YE56 appeared only at stationary phase in the same medium. Although there is always a Iag in arsenite oxidation, when YE56 is grown in richer media, arsentte oxidation does occur during exponential growth. Since sewage Is a rich medium, arsenite oxidation probably occurs earlier than under the minimal conditions used in the laboratory as long as oxygen is arailable. The factor initiating induction is still unknown, but this study suggests the possibility that some factor, ("secondary metabolite:), produced at stationary phase or supplied in yeast extract medium is essential for the synthesis of the enzyme or the conversion of an antecedent enzyme into an active form, or the synthesis of a specific cytochrome associated with arsenite oxidation. For example, E. coli grown In peptone meat-extract agar, as well as cells of $\underline{\mathrm{E}}$. coli grown anaerobically In a complex medium containing no nitrate, showed spectral characteristics of cytochromes $b_{1}, a_{1}$, and $a_{2}$. In contrast $\underline{E}$. coli cells grown anaerobically in a semi-synthetic medium containing nitrate showed peaks at $552 \mathrm{~mm}$ and at $560 \mathrm{~nm}$. The adsorption spectrum of the c type cytochrome (called c-552) was closely similar and probably Identical with that of the c type cytochrome reported by Gray et al., (Fujita, 1965a). Cytochrome c-552 was found to be aucooxidizable and localized 
at the cell surface (Fuffta et al., 1966). Anaerobic biosynthesis of this protein is enhanced in the presence of nitrite and strongly repressed by oxygen suggesting an involvement in anaeroblc nitrite metabolism (Fujita, 1966b).

The development of an enzyme system for the oxidation of arsenite (as would be produced by Pseudomonas acidovorans-arsenoxydans) to the less toxic arsenate could be a protective mechanism. However, the abllity to oxidize arsenite is not essential to a tolerance of high arsenite concentrations (0.02 M) since several organisms including a gram negative rod, a spore-forming, gram positive rod and a yellow, gram negative rod were isolated which tolerated $0.02 \mathrm{M}$ arsenite but could not oxidize or reduce arsenite or convert it to organic arsenicals.

Evidence has been presented that one manner by which YE56 could protect itself before induction of the arsente oxidizing system is the binding of arsenite to the cell wall-envelope. This is supported by the demonstration that YE56 is able to grow anaerobically using nitrate as a terminal electron acceptor, although under these same conditions it cannot oxidize arsenite.

Although the enzymes, pyruvate and alpha-ketoglutarate dehydrogenase are known to be sensitive to arsenite (Mahler and Cordes, 1966), those of YE56 must be different since oxygen uptake estimated with the oxygen probe was the same when substrate was added to induced cells botk with and without arsenite.

The experimental system reported here was artifical and much different from the complex environment of sewage but the interactions 
proposed in this paper are of revelence to the discovery. of the critical, yet subtle difference, which exists between other-spectes and pseudomonads allowing only them to f111 the niche of arsenite oxidizers In sewage.

In conclueion with the banning of peetictdes such as DDT, dieldrin, and aldrin, the public will probably find a return to the use of arsentcals as pesticides. Since there is so much uncertainty as to the form of arsenic in nature as it is measured currently, the literature and investigators should redefine their determinations to include the form (organic or 1norganic) and oxidation state of the arsenical determined. For example, when Angino et al., (1970) found total arsenic levels of 2-8 $\mathrm{ppb}$ in the Kansas River, they noted that the upper values found in the river were close to maximum values of $10 \mathrm{ppb}$ total arsenic allowable in drinking water by the United States Public Health Service. Since the two forms of arsenic (arsenite and arsenate) have very different toxicities, it is important to know the oxidation sitate, and furthermore, since this work outlines a method for distinguishing between the arsenite and arsenate, the Public Health Service should set new tolerance limits commensurate with the toxicities of each form of arsenic and investigators should report the form of arsenic in addition to the quantity. 


\section{REFERENCES}

Alexander, M. 1970. Microblal Ecology. New York, John Wiley and Sons. p. 87 .

Amertcan Society for Microblology. 1957. Manual of Microbiological Methods. New York, McGraw-Hill Book Co., Inc.

Angino, E. E., L. M. Magnuson, T. C. Waugh, O. K. Galle, and J. Bredfeldt. 1970. Arsenic in detergents: Possible danger and pollution hazard. Science 168:389.

Anderson, R. and E. McCoy. 1963. Floc forming bacteria from activated sludge (RT8). Bacteriol. Proc. p. 162.

Arima, K. and T. J. Oka. 1965. Cyanide resistance in Achromobacter I. Induced formation of cytochrome $a_{2}$ and its role in cyanideresistant respiration. J. Bacteriol. 90:734.

Association of Official Analytical Chemists. 1970. Official Methods of Analysis. Wash., D. C. Association of Official Analytical Chemists. p. 402 .

Barron, E. S. G. 1951. Thiol groups of biological importance. Adv. Enz. 11:201.

Bauchop, T. and S. R. Eldsen. 1960. The grrwth of micruorganisms in relation to their energy supply. J. Gen. Microbiol. $23: 457$.

Botsford, J. L. and R. D. DeMoss. 1971. Catabolite repression of tryptophanase in Escherichia coli. J. Bacteriol. 105:303.

Bul1, A. T. 1970. Inhtbition of polysaccharases by melanin: Enzyme inhibition in relation to myeolysis. Arch Biochem. Biophys. 137:345.

Campbe11, L. L. 1954. The growth of an "obligate" thermophilic bacterium at $36^{\circ} \mathrm{C}$. J. Bacteriol. 68:505.

Chakrabarty, A. 1952. Genetic Basis of the Blodegration of Salicylate in Pseudomonas. J. Bacteriol. 112:815.

Challenger, F. 1945. Biological methylation. Chem. Rev. 36:315.

Cohn, M. 1957. Contributions of studies on the beta-galactosidase of Escherichia coli to our understanding of enzyme synthesis. Bacterio1. Rev. 21: 140 .

Crane, R. K. and F. Lipmann. 1953. The effect of arsenate on aerobic phosphorylation. J. Biol. Chem. 201:235. 
DeVoe, I. W. and E. L. Oginsky. 1969. Antagonistic effect of monovalent cations in maintenance of cellular integrity of a marlne bacterium. J. Bacteriol. 98:1355.

Doudoroff, M., H. A. Barker and W. Z. Hassid. 1947. III. ArsenoIytic decomposition of sucrose and glucose-1-phosphate. J. Biol. Chem. 170:147.

E11wood, D. L. and D. W. Tempest. 1967. Influence of growth conditions on the celi wall content and wall composition of Aerobacter aerogenes. Biochem. J . 105:9p.

Fiske, C. H. and X. Subbarow. 1925. The colorimetric determination of phosphorus. J. Biol. Chem. 66:375.

Forrest, W. W. 1963. Energetic aspects of microbial growth. In Metabolic Inhibitors 2. Eds. R. M. Hochster and J. H. Quaste1. New York Academic Press.

Fuj1ta, T. 1966a. Studies on soluble cytochromes in Enterobacteriaceae. I. Detection, purification and properties of cytochrome c-552 in anaerobically grown cells. J. Biochem. 60:204.

Fujita, T. 1966b. Studies on soluble cytochromes in Enterobacteriaceae. IV. Possible Involvement of cytochrome c-552 in anaerobic aitrite metabolism. J. Biochem. 60:691.

Fujita, T. and R. Sato. 1967. Studies on soluble cytochromes in Enterobacteriaceae. V. Nitrite-dependent gas evolution in cells containing cytochrome c-552. J. Biochem. 62:230.

Gaby, W. L., C. Logan, and S. Whitaker. 1962. Catabolism of nitrogenous compounds by Pseudomonas. J. Gen. Microbiol. 28: 379 .

Gale, E. F. and H. M. R. Epps. 1942. The effect of pH on the medium during growth on the enzyme activities of bacteria (Escherichia coli and Micrococcus lysodeikticus) and the biological significance of the changes produced. Biochem. J. $36: 600$.

Gibson, J. 1957. Nutrifional aspects of microbial ecology. In Microbial Ecology. 7th Symposium. Cambridge at the Univ. Press: Society for General Microbiology.

Gilreath, E. S. 1969. Elementary Quantitative Chemistry. San Francisco: W. H. Freeman and Company.

Green, H. H. 1918. Isolation and description of a bacterium causing oxidation of arsenite to arsenate in catele dipping baths. Rep. D1r. Vet. Res. S. Afr. 5-6:593. 
Grunert; R. R. and E. L. Rohdenburg. 1960. Alpha-1ipoic acid and heavy metal inhibition of the pyruvic oxidase enzyme system of Streptococcus faecalis 10C1. Arch. Biochem. Biophys. $86: 185$.

Harrison, Tom. Pesticide Supervisor Plant Division, Oregon State Department of Agriculture. Personal communication.

Heinen, W. 1971. Inhibitors of electron transport and oxidative phosphorylation. In Methods in Microbiology 6A. Eds. J. R. Norris and D. W. Ribbons. New Yorik Academic Press.

Hernandez, E. and M. J. Johnson. 1967. Energy supply and cell yield in aerobically grown microorganisms. J. Bacteriol. 94:996.

Holding, A. J. and J. G. Collee. 1971. Routine biochemical tests. In Methods in Microbiology 6A. Eds. J. R. Norris and D. W. Ribbons. New York Academic Press.

Holloway, B. W. 1969. Genetics of Pseudomonas. Bacterio1. Rev. $33: 419$.

Hospodka, J. 1966. Oxygen-adsorption rate-controlled feeding of substrate into aernhic microbial cultures. Biotechnol. Bioengng. 8:117.

Hou, C. I., A. F. Gronlund, and J. J. R. Campbell. 1966. Influence of phosphate starvation on cultures of Pseudomonas aeruginosa. J. Bacteriol. 92:851.

Hughes, A. H., M. Stow, I. C. Hancock and J. Biddiley. 1971. Function of teichoic acids and effect of novobiocin on control of magnesium at the bacterial membrane. Nature 229:53.

Johnson, F. H. 1957. The action of pressure and temperature. In Microbial Ecology 7th Symposium. Cambridge at the Univ. Press: Society for General Microbiology.

Jones, M. E. 1962. Carbamyl phosphate synthesis and utilization. In Methods in Enzymology 5. Eds. S. P. Colowick and N. 0 . Raplan. New York Academic Press.

Katz, J. and W. Z. Hassid. 1951. Arsenolysis of amylose and anylopectin. Arch. Biochem. 30:272.

Koch, A. L. 1961. Some calculations on the turbidity of mitochondria and bacterla. Biochim. Biophys. Acta 51:429.

Levvy, G. A. 1943. The iodometric micro-determination of arsenite in blological material. Blochem. J. 37:598. 
Lester, R. L. 1967. Acetone-treated particles CoQ deficient. In Methods in Enzymology 10. Eds. R. A. Estab rook and W. E. Pullman. New York Academic Press.

Lowry, O. H., N. J. Ros enbrough, A. L. Farr, and R. J. Randall. 1951. Protein measurement with the folin phenol reagent. J. Biol. Chem. 193:265.

Mahler, H. and E. Cordes. 1966. Biological Chemistry. New York Harper and Row Publishers.

Mayberry, W. R., G. J. Prochazka and W. J. Payne. 1967. Growth yields of bacteria on selected organic compounds. Appl. Microbiol. 15:1332.

Meyne11, G. G. and E. Meyne11. 1965. Theory and Practice in Experimental Bacteriology. London's Cambridge Univ. Press. p. 34 .

Monod, J. 1949. The growth of bacterlal cultures. Ann. Rev. Microbiol. 3:371.

Munro, A. L. S. 1970. Measurement and control of $\mathrm{pH}$ values. In Methods in Microblology 2. Eds. J. R. Norris and D. W. Ribbons. New York Academic Press.

Neu, H. C., and L. A. Heppel. 1965. The release of enzymes from Escherichia coli by osmotic shock and during the formation of spheroplasts. J. Biol. Chem. 240:3685.

Ornston, L. N., M. K. Ornston, and G. Chou. 1969. Isolation of spontaneous mutant strains of Pseudomonas putida. Biochem. Biophys. Res. commun. 36:179.

Payne, W. J. 1970. Energy yield and growth of heterotrophs. Ann. Rev. Microbiol. 24:17.

Perlman, R. L., B. DeCrombrugghe and I. Pastran. 1969. Cyclic AMP regulates catabolite repression and transient repression in Escherichia coli. Nature 223:810.

Peters, R. A., H. M. Sinclair, and R. H. S. Thompson. 1946. An analysis of the inhibition of pyruvate oxidation by arsenicals in relation to the enzyme theory of vesication. Biochem. $J$. $40: 516$.

Phillips, D. H. and M. J. Johnson. 1942. Aeration in fermentation. J. Blochem. Microbiol. Techn. Eng. 3:277.

Rieman; N., J. D. Neuss, and B. Naiman. 1942. Quantitative Analysis. A Theoretical Approach. New York McGraw-Hill Book Co., Inc. p. 208 . 
Sanadi, D. R., M. Langley, and F. White. 1958. On the mechanism of oxidative decarboxglation of alpha-keto acids. Biochim. Biophys. Acta. 29:218.

Schroeder, H. A. and J. J. Balassa. 1966. Abnormal trace elements in man:Arsenic. J. Chron. Dis. 19:85.

Seiji, M. and S. Iwashita. 1965. E- zyme inactivation by ultraviolet light protective effect of melanin. J. Blochem. $57: 457$.

Shapiro, J. 1971. Arsenic and phosphate measured by various techniques. Sclence 171:234.

Sinclair, N. A. and J. L. Stokes. 1963. Role of oxygen in the high cell yields of psychrophiles and mesophiles at low temperatures. J. Bacteriol. 85: 164 .

Singer, C. E. and B. N. Ames. 1970. Sunlight ultraviolet and bacterial DNA base ratios. Science 170:822.

Skerman, V. B. D. 1967. A Guide to the Identification of the Genera of Bacteria. Baltimore:Williams and Wilkins Company.

Stanler, R. Y., N. J. Palleroni, and M. Doudoroff. 1966. The aerobic pseudomonads: A taxonomic study. J. Gen, Microbiol. 43:159.

State of California. 1963. Water Quality Criteria. Sacramento: State Water Pollution Control Board Publication No. 3-A.

Terwe1I, H. F. and E. C. Slater. 1964. Uncoupling of respiratorychain phosphorylation by arsenate and evidence for the axistance of a stable X intermediate of oxidative phosphorylation. Biochim. Biophys. Acta 89:385.

Thimann, K. V. 1963. The Life of Bacteria. New York MacMillan Company. p. 633 .

Thornley, M. J. 1960. The differentiation of Pseudomonas from other gran segative bacteria on the basis of arginine metabolfsm. J. App1. Bacteriol. 23:37.

Turner, A. W. 1949. Bacterial oxidation of arsenite. Nature 164:76.

Umbreit, W. W., R. H. Burns, and J. F. Stauffer. 1957. Manometric Techniques. Minneapolis Burgess Publishing Co.

Deda, S. and L. Earle. 1972. Microflora of activated sludge. J. Gen. App1. Microbiol. 18:239. 
J. S. Department of Agriculture. 1957. Yearbook of Agriculture. Wash. D. C. U. S. Government Printing Office. p. 166.

Welsh, J. H., R. I. Smith, A. E. Dammer. 1968. Laboratory Exercises in Invertebrate Physiology. Minneapolis Burgess Publishing Co.

Wilkinson, R. E. and W. S. Hardcastle. 1969. Plant and soil arsenic analyses. Weed Science 17:536.

Zobell, C. E. and F. H. Johnson. 1949. The influence of hydrostatic pressure on bacteria. J. Bacteriol. 57:179. 